UNIVERSIDADE DE SÃO PAULO

FACULDADE DE ODONTOLOGIA DE RIBEIRÃO PRETO

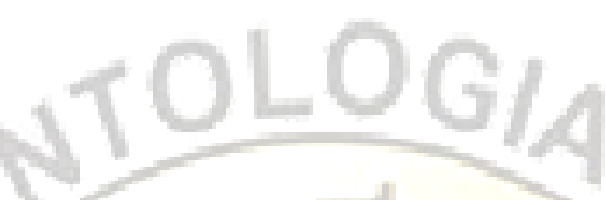

PAOLA KIRSTEN MIANI

Avaliação de um gel contendo metronidazol para o tratamento adjuvante da periodontite crônica

Ribeirão Preto 


\section{Avaliação de um gel contendo metronidazol para o tratamento adjuvante da periodontite crônica}

Tese apresentada à Faculdade de Odontologia de Ribeirão Preto da Universidade de São Paulo para a obtenção do título de Doutora em Odontologia. Área de concentração: Reabilitação Oral Orientador: Prof. Dr. Vinícius Pedrazzi

Ribeirão Preto 
AUTORIZO A REPRODUÇÃO E DIVULGAÇÃO DO TEOR TOTAL OU PARCIAL DESTE TRABALHO POR QUALQUER MEIO CONVENCIONAL OU ELETRÔNICO, PARA FINS DE ESTUDO E PESQUISA, DESDE QUE CITADA A FONTE.

Ficha catalográfica elaborada pela Biblioteca Central do Campus USP Ribeirão Preto

Miani, Paola Kirsten

Avaliação de um gel contendo metronidazol para o tratamento adjuvante da periodontite crônica. Ribeirão Preto, 2010.

170 p. : il. ; $30 \mathrm{~cm}$

Dissertação de Mestrado, apresentada à Faculdade de Odontologia de Ribeirão Preto/USP. Área de Concentração: Reabilitação Oral.

Orientador: Pedrazzi, Vinícius.

1. Metronidazol. 2. Gel. 3. Periodontite.

4. Sistema de liberação de fármacos.

5. Hibridização DNA-DNA Checkerboard. 


\section{FOLHA DE APROVAÇÃO}

Paola Kirsten Miani

Avaliação de um gel contendo metronidazol para o tratamento adjuvante da periodontite crônica.

Dissertação apresentada à Faculdade de Odontologia de Ribeirão Preto, da Universidade de São Paulo, para obtenção do título de Doutora em Odontologia.

Área de Concentração: Reabilitação Oral

Aprovada em:

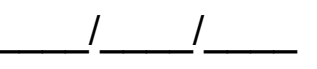

Banca Examinadora:

1) Prof.(a). Dr.(a).:

Instituição:

Julgamento:

Assinatura:

2) Prof.(a). Dr.(a).:

Instituição:

Julgamento:

Assinatura:

3) Prof.(a). Dr.(a).:

Instituição:

Julgamento:

Assinatura:

4) Prof.(a). Dr.(a).:

Instituição:

Julgamento:

Assinatura:

5) Prof.(a). Dr.(a).:

Instituição:

Julgamento:

Assinatura: 
Dedico este trabalho

À minha filha Rafaela, razão do meu viver, que mesmo tão pequenina, foi capaz de suportar a minha ausência e a escassa atenção, muitas vezes implorada, para que este desafio pudesse ser concretizado, mas com toda certeza foi a minha grande companheira e maior fonte de alegria e motivação nesta longa jornada. 


\section{Agradecimentos especiais}

Ao meu marido Fábio, por toda paciência, carinho e dedicação com que tolerou meus anseios e a falta de atenção durante esta etapa da minha vida

Ao querido Prof. Dr. Vinícius Pedrazzi, meu orientador,

pela receptividade e oportunidade de aperfeiçoamento profissional, por todos os ensinamentos prestados com muita dedicação, sabedoria e serenidade, pela compreensão nos momentos difíceis, pela confiança e constante incentivo,

E acima de tudo pelo carinho e amizade

demonstrados em todos os momentos compartilhados

Meus sinceros agradecimentos 


\section{Agradecimentos}

A Deus pela presença constante e por ter me dado força para vencer mais um desafio.

À Faculdade de Odontologia de Ribeirão Preto, da Universidade de São Paulo, a qual considero minha segunda casa e da qual tenho um imenso orgulho, por todo conhecimento adquirido durante todos estes anos, onde obtive minha formação como Cirurgiã-Dentista e Mestre e pela oportunidade da realização do curso de Doutorado nas pessoas do Diretor Prof. Dr. Osvaldo Luiz Bezzon e do Vice-Diretor Prof. Dr. Valdemar Mallet da Rocha Barros.

Aos docentes do Departamento de Materiais Dentários e Prótese da Faculdade de Odontologia de Ribeirão Preto, nas pessoas da chefe de Departamento Profa. Dra. Helena de Freitas Oliveira Paranhos e da Vice-chefe Profa. Dra. Fernanda de Carvalho Panzeri Pires de Souza, pelo afável convívio e pela contribuição indispensável para minha formação como Doutora.

À Coordenadora do Programa de Pós-Graduação na área de Reabilitação Oral, Profa. $D^{r}$. Fernanda Panzeri e à sua antessessora Profa. Dra Iara Augusti Orsi, pelo excelente trabalho realizado no curso, pelo apoio e incentivos constantes.

À Profa. Dra. Mariane Gonçalves, minha orientadora no mestrado, por quem tenho imensa admiração e carinho, pelos inestimáveis ensinamentos, os quais foram a base para minha evolução profissionale intelectual.

Às funcionárias do Departamento de Materiais Dentários e Prótese, Regiane de Cássia Tirado Damasceno, Ana Paula Xavier e Ana Paula Macedo, pelos esclarecimentos constantes, pela paciência em me ajudar sempre que precisei e principalmente pela sincera amizade adquirida durante este tão agradável convívio.

A todos os funcionários do Departamento de Materiais Dentários e Prótese, e da FORP-USP, pela alegre convivência e pela boa vontade com que me ajudaram sempre que foi preciso. 
À Izabel Cristina Galino Sola e à Regiane Cristina Moi, secretárias da pós-graduação, eficientes e responsáveis durante a jornada de trabalho e pela disponibilidade em me atender sempre que necessário.

À Profa. Dra. Maria José Vieira Fonseca, do Departamento de Ciências Farmacêuticas a Faculdade de Ciências Farmacêuticas de Ribeirão Preto - USP, pela gentileza com que me recebeu em seu laboratório e pelos ensinamentos valiosos para a realização do trabalho.

Ao farmacêutico José Orestes Del Ciampo, técnico da Faculdade de Ciências Farmacêuticas de Ribeirão Preto - USP, pela disponibilidade e pelo preparo do gel experimental testado neste trabalho.

Ao químico José Roberto Jabor, técnico da Faculdade de Ciências Farmacêuticas de Ribeirão Preto - USP, pela amizade, paciência e dedicação na realização das análises cromatográficas.

À amiga Sandra Sato, pela imensa colaboração durante todas as fases deste trabalho, pelos ensinamentos e pela paciência com que atendeu aos meus questionamentos, e principalmente pela amizade e agradável convívio.

Aos alunos de iniciação científica Lidiane Peressim, Natália Cantarella e Rafael Simões, ao colega Alexandre Vicentini e à querida amiga Ana Julieta Rosa e Silva, por toda ajuda prestada para a realização desta pesquisa.

À Andréa Marcaccini, periodontista e pós-doutoranda, pela amizade e valiosas contribuições durante a elaboração deste trabalho.

Às queridas amigas, também colegas de pós-graduação, Ana Carolina Maito Villela Rosa, Pámela Carbone Melo e Natércia Soriane, especialmente pela amizade, 6ons momentos compartilfados e auxílios constantes. 
Um agradecimento especial ao amigo Cássio do $\mathcal{N a s c i m e n t o , ~ p e l o ~ a u x i ́ l i o ~ i m p r e s c i n d i ́ v e l ~}$ para a realização deste trabalho, pelo companheirismo, amizade, generosidade, e sobre tudo, pelo exemplo de competência e de caráter, que o fazem tão admirável.

À Tereza Cristina Ribeiro Dias Koberstein, minha querida prima, por todo incentivo ao meu crescimento profissional e pelas ajudas de última hora.

À Mafalda Tonicelo Catholico, minha sogra, pela receptividade em sua casa e apoio durante todo o curso de doutorado.

À Creche Carochinha da Faculdade de Odontologia da USP de Ribeirão Preto, cuja contribuição foi fundamental para que eu pudesse cursar o doutorado, por todo carinho e cuidado com que acolheu a minha filha durante minha ausência.

Aos voluntários desta pesquisa: Pessoas incríveis que se prontificaram a contribuir com a pesquisa em saúde. Pela confiança em meu trabalho, pela solicitude e, acima de tudo, pela colaboração em benefício do bem comum.

'À Fundação de Amparo à pesquisa do Estado de São Paulo, pelo apoio financeiro essencial para a realização deste trabalho.(Processo FAPESP :07/03503-2).

À Capes (Coordenação de Aperfeiçoamento de Pessoal de Nível Superior do Ministério da Educação - MEC), pela bolsa de estudo fornecida, que me auxiliou em muito neste momento tão importante de minha vida.

A todos que, direta ou indiretamente, colaboraram com a realização deste trabalho.

\section{Muito obrigada.}


MIANI, PK. Avaliação de um gel contendo metronidazol para o tratamento adjuvante da periodontite crônica. 2010. 170 f. Tese (Doutorado) - Faculdade de Odontologia de Ribeirão Preto, Universidade de São Paulo, Ribeirão Preto, 2010.

\section{RESUMO}

Sistemas poliméricos para a liberação de fármacos associados à terapêutica periodontal convencional têm sido desenvolvidos e aplicados com algumas vantagens em comparação ao debridamento mecânico isolado. Um dispositivo de liberação lenta para uso em bolsas periodontais contendo metronidazol como princípio ativo, foi desenvolvido e testado quanto à sua eficácia no tratamento de pacientes com periodontite crônica. Dezesseis pacientes foram selecionados e aleatoriamente alocados aos seguintes tratamentos com 8 indivíduos por grupo: 1) raspagem e alisamento radicular (controle ativo) ou 2) raspagem e alisamento radicular + aplicação de gel contendo metronidazol a 15\% (experimental). Os efeitos dos tratamentos foram avaliados pelo acompanhamento longitudinal de parâmetros clínicos (profundidade do sulco gengival à sondagem e nível clínico de inserção) e microbiológicos (análise da microbiota subgengival pela técnica da hibridização DNA-DNA Checkerboard). O monitoramento das concentrações de metronidazol no fluido gengival colhido dos pacientes que receberem o gel foi realizado pela cromatografia líquida de alta eficiência. Os resultados da análise das concentrações de metronidazol na bolsa periodontal demonstraram que o gel só pôde ser detectado em concentrações efetivas até uma hora depois da aplicação. Em relação à análise microbiológica, foi observada diferença significante entre os grupos, nos três tempos de avaliação (antes, 7 e 30 dias depois do tratamento). A análise intragrupos indicou redução significante na contagem bacteriana somente para o grupo tratado com o gel de metronidazol, após 7 dias do tratamento. Embora tenha sido detectada diferença entre os grupos nenhum deles foi capaz de eliminar ou reduzir com significância as espécies periodontopatogênicas. No que se refere aos parâmetros clínicos, ambas as terapias foram eficazes em promover a redução na profundidade à sondagem e o ganho no nível de inserção, sem benefício significante para o emprego do gel de metronidazol.

Palavras-chave: Metronidazol. Gel. Periodontite. Dispositivo de liberação lenta. Hibridização DNA-DNA checkerboard, 
MIANI, PK. Evaluation of a gel containing metronidazole for the adjuvant treatment of chronic periodontitis . 2010. $170 \mathrm{f}$. Thesis (Doctoral) - Faculdade de Odontologia de Ribeirão Preto, Universidade de São Paulo, Ribeirão Preto, 2010.

\section{ABSTRACT}

Polymeric systems for drug delivery have been developed and implemented with several advantages compared to conventional therapy. A slow-release device for use in periodontal pockets containing metronidazole as active principle, was developed and tested for its efficacy in treating patients with chronic periodontitis. Sixteen patients were randomly allocated to treatments with eight subjects per group: 1) scaling and root planing (active control) or 2) scaling and root planing + application of $15 \%$ metronidazole gel (experimental). Treatment effects were assessed by longitudinal clinical parameters (gingival sulcus depth probing and clinical attachment level) and microbiological (analysis of subgingival microbiota by the technique of checkerboard DNA-DNA hybridization). The monitoring of concentrations of metronidazole in the gingival fluid collected from the patients receiving the gel was performed by high performance liquid chromatography. The results of the analysis of concentrations of metronidazole in periodontal pockets showed that the gel could only be detected at effective concentrations until one hour after application. Regarding microbiological analysis there was significant difference between groups in the three evaluated times (before, 7 and 30 days after treatment). The intragroup analysis showed a significant decrease in bacterial count only for the group treated with metronidazole gel after 7 days of treatment. Although difference was detected between both groups, none of them was able to eliminate or significantly reduce the periodontopathogenic species. With regard to clinical parameters, both therapies were effective in promoting reduction in depth probing and gain in attachment level, without significant benefit to the use of metronidazole gel.

Keywords: Metronidazole. Gel. Periodontitis. Slow release device. Checkerboard DNA-DNA hybridization. 


\section{LISTA DE SIGLAS E ABREVIATURAS}

ATCC American Type Culture Collection

CIM Concentração inibitória mínima

CLAE Cromatografia Líquida de alta eficiência

DNA Ácido desoxirribonucelico (Deoxyribonucleic acid)

ELISA Ensaio imunobsorbente ligado à enzima (Enzyme Linked Immuno Sorbent Assay)

EDTA Ácido etilenodiamino tetra-acético (Ethylenediamine tetraacetic acid)

HCL Cloreto de hidrogênio

MMP Metaloproteinase da matriz (matrix metalloproteinase)

$\mathrm{NaOH} \quad$ Hidróxido de sódio

PCR Reação em cadeia da polimerase (Polymerase Chain Reaction)

PDLGA Poly (DL-lactide-co-glycolide)

PLGA Poly (L-lactide-co-glycolide)

PDLLA Poly (DL-lactic acid)

RAR Raspagem e alisamento radicular

Tris Tris (hidroximetil) aminometano (tris- hidroxymetyl aminomethane)

Tris HCL Tris Hidrocloreto

TE Solução tampão - Tris-HCL/EDTA

UV Ultra violeta 


\section{SUMÁRIO}

1 INTRODUÇÃO

2 REVISTA DA LITERATURA

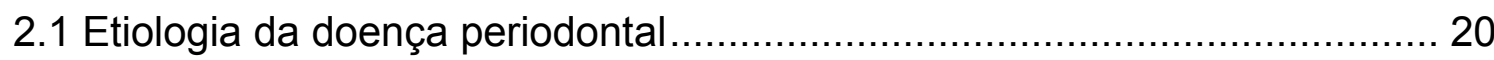

2.2 Antibióticos no tratamento da doença periodontal .................................... 25

2.3 Sistemas de liberação de fármacos no tratamento da periodontite ............ 32

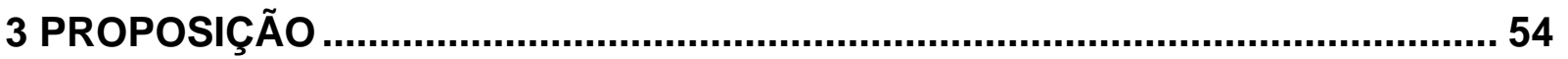

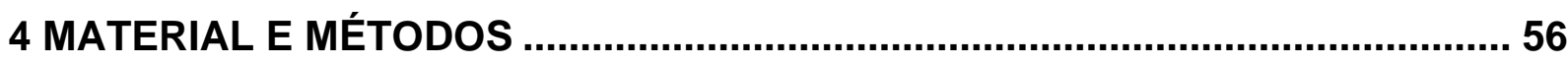

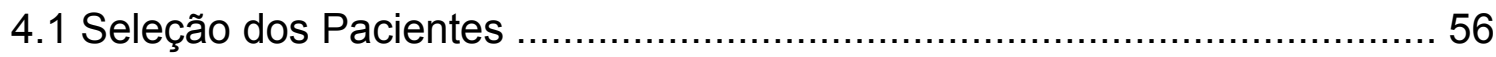

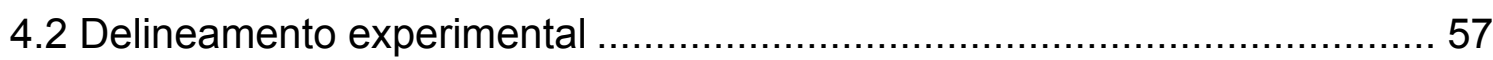

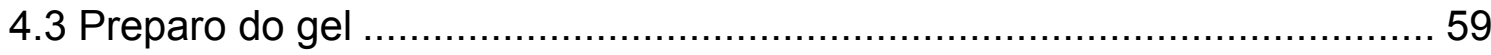

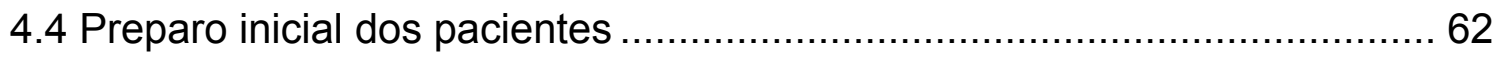

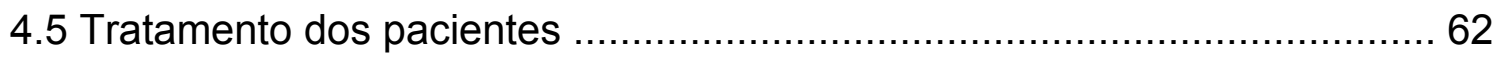

4.6 Monitoramento das concentrações de metronidazol no fluido gengival ...... 63

4.6.1 Colheita das amostras de fluido gengival para quantificação do

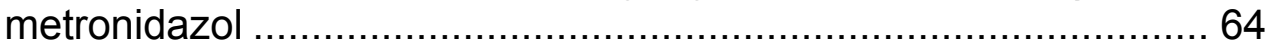

4.6.2 Determinação das concentrações de metronidazol nas amostras por CLAE

4.6.2.1 Processamento das amostras para análise pela CLAE ..... 68

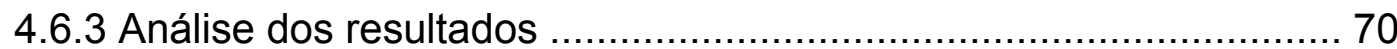

4.7 Avaliação dos indicadores clínicos da periodontite .................................. 71

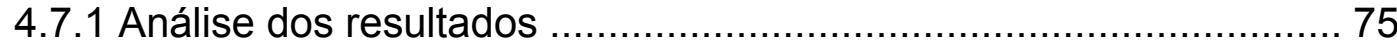

4.8 Avaliação dos indicadores microbiológicos da periodontite ....................... 75

4.8.1 Colheita das amostras de biofilme subgengival............................ 75

4.8.2 Análise da microbiota bucal pelo método DNA Checkerboard ........ 76

4.8.2.1 Obtenção das sondas de DNA genômico .......................... 77

4.8.2.2 Processamento das amostras pela técnica de hibridização DNA Checkerboard ................................................ 79

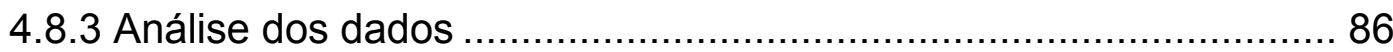


5 RESULTADOS

5.1 Resultado do monitoramento da concentração de metronidazol no fluido gengival.

5.2 Resultados da análise dos parâmetros clínicos ................................. 89

5.2.1 Profundidade de sondagem ................................................... 90

5.2.2 Nível clínico de inserção................................................... 92

5.3 Resultados da análise microbiológica pelo método DNA Checkerboard. ... 94

6 DISCUSSÃO

6.1 Monitoramento das concentrações de metronidazol............................... 103

6.2 Parâmetros clínicos .................................................................... 110

6.3 Parâmetros microbiológicos ............................................................. 114

7 CONCLUSÕES

REFERÊNCIAS

APÊNDICES

APÊNDICE A - Quadros demonstrativos da análise estatística realizada, gerada pelo programa NCSS

APENDICE B - Quadros demonstrativos da análise estatística realizada, gerada pelo Programa GraphPad Instat.

APENDICE C - Imagem demosntrativa de um cromatograma após a análise pela CLAE

ANEXOS

ANEXo 1 - Certificado de Aprovação do Projeto pelo Comitê de Ética em Pesquisa da Faculdade de Odontologia da Forp-USP

ANEXO 2 - Exemplo do Termo de Compromisso assinado pelos voluntários da pesquisa 
1 Introdução 


\section{INTRODUÇÃO}

As doenças periodontais são reações inflamatórias localizadas, que afetam as estruturas de suporte dos dentes. Nos estágios iniciais da doença, há um acúmulo de um biofilme bacteriano dentário na região supragengival, estimulando a inflamação dos tecidos gengivais, conhecida como gengivite. À medida que a inflamação progride mais profundamente nos tecidos periodontais de suporte, um espaço, conhecido como bolsa periodontal, é formado entre as raízes dos dentes afetados e os tecidos moles.

Nesse nicho protegido, o biofilme subgengival se organiza e a condição inflamatória passa então a se chamar periodontite. Com a progressão da doença, ocorre um aumento da mobilidade dentária, devido à migração apical do epitélio juncional e reabsorção do osso adjacente ao dente e, ao final do processo, pode ocorrer a perda do elemento dental.

Há um consenso de que a infecção bacteriana seja a causa primária da doença periodontal, e, portanto, tem sido estabelecido que os microrganismos presentes na cavidade bucal representam um importante fator etiológico das periodontites (LÖE; THEILADE; JENSEN, 1965; SOCRANSKY, 1977; LINDHE, 2005). O acúmulo de placa bacteriana no sulco gengival estimula a liberação de várias toxinas, e para impedir que os microrganismos se disseminem e invadam os tecidos, o hospedeiro responde a esta infecção por meio de processos inflamatórios 
e imunológicos, os quais podem gerar a destruição tecidual, e consequentemente, a perda de inserção. (ARMITAGE, 1994; HAAKE et al., 2004; AZUMA, 2006).

Neste sentido, o controle do acúmulo de biofilme bacteriano sobre os dentes, realizado por meio da escovação diária, constitui um meio efetivo para a prevenção da inflamação e desenvolvimento da doença periodontal (CARRANZA; NEWMAN, 1998). No entanto, este procedimento não é suficiente quando o processo inflamatório se encontra em estágios mais avançados (KALDAHL et al., 1996). Nestes casos, a intervenção profissional se faz necessária.

O tratamento convencional das periodontites consiste na remoção mecânica, pelo Cirurgião-dentista, do biofilme e cálculo dentário supra e subgengival por meio do procedimento de raspagem e alisamento radicular (RAR), com o objetivo de promover uma desinfecção local (BADERSTEN; NILVEUS; EGELBERG, 1984). Uma resposta favorável após os procedimentos de instrumentação subgengival resulta de uma significativa redução da microbiota patogênica (CUGINI et al., 2000; FERES et al., 2001), tendo em vista o importante papel das bactérias no desenvolvimento da doença periodontal.

Em bolsas mais profundas, entretanto, existe uma maior dificuldade em se realizar a raspagem de maneira completa e eficiente (MAGNUSSON et al, 1984). Nesses casos, pode-se lançar mão de técnicas cirúrgicas para o tratamento dessas bolsas periodontais remanescentes, ou ainda de antimicrobianos, especialmente em infecções periodontais mais severas.

A maioria das formas de periodontite é representada por infecções causadas pelo crescimento excessivo de um número determinado de bactérias anaeróbias Gram-negativas. Vários antibióticos foram testados e utilizados como tratamento independente da terapêutica mecânica, ou como auxiliares desta, sendo 
os mais utilizados, a tetraciclina, a doxiciclina, a minociclina, o metronidazol e a associação do metronidazol com amoxicilina.

Dessa forma, condutas terapêuticas baseadas na administração sistêmica ou local de agentes antimicrobianos visando à erradicação ou pelo menos redução de patógenos específicos têm sido propostas no combate destas infecções.

Dentre os agentes antimicrobianos propostos para o tratamento das periodontites, o metronidazol, desenvolvido na França em 1957 para tratamento de infecções causadas por protozoários, demonstrou grande utilidade em Odontologia ao promover a cura da gengivite ulcerativa necrosante em pacientes portadoras de tricomoníase vaginal, durante o tratamento com o fármaco (SHINN, 1962; SHINN; SQUIRES; MCFADZEAN, 1965; LEKOVIC, 1983).

O metronidazol é um composto sintético, bactericida, que atua mediante a inibição da síntese do DNA dos microrganismos. Este fármaco tem se mostrado particularmente adequado devido ao seu espectro de ação, restrito aos microrganismos anaeróbios estritos, os quais estão entre os implicados nessas infecções periodontais, além de ter limitados efeitos colaterais quando comparados com as tetraciclinas, por exemplo, como seleção de bactérias multi-resistentes ou perturbação da microbiota normal do organismo (LÖFMARK; EDLUND; NORD, 2010).

O uso sistêmico de antibióticos traz consigo algumas preocupações. A administração prolongada aumenta o risco de problemas como desenvolvimento de resistência a antibióticos e surgimento de efeitos adversos, como náuseas, diarréia ou outros problemas gastrintestinais.

No final da década de 70 , foi proposta a utilização de sistemas de liberação de fármacos intra-bolsa periodontal, e desde então, inúmeras pesquisas 
vêm sendo realizadas com foco no desenvolvimento de sistemas capazes de prolongar e/ou controlar a concentração do fármaco no sítio de aplicação, de forma a se obter concentrações ideais do fármaco somente nos locais onde ele é necessário, o que minimiza os efeitos colaterais associados ao uso sistêmico dos antibióticos.

Diferentes compostos e formas de apresentação desses sistemas têm sido desenvolvidos, sendo portando, necessária a avaliação do comportamento e eficácia destes fármacos; porém, atingir o objetivo, não é tarefa fácil, devido às restrições anatomofisiológicas inerentes às bolsas periodontais. Sendo assim, é premissa deste estudo clínico e laboratorial, a análise da liberação controlada de um gel de metronidazol a $15 \%$ e de seus resultados clínicos e microbiológicos, como coadjuvante da terapia periodontal básica em pacientes com periodontite crônica. 
2 Revista da Literatura 


\section{REVISTA DA LITERATURA}

A doença periodontal apresenta um mecanismo etiológico muito complexo, e o controle do biofilme dentário, debridação do cálculo dentário, remoção clínico-cirúrgica de bolsas, com meticulosa higiene mecânico-química bucal, ainda são as ações mais efetivas para a recuperação da saúde periodontal. Adicionalmente a essas terapias, muito se tem pesquisado sobre o uso de medicação sistêmica e local com agentes antimicrobianos já consagrados na literatura, e outros experimentais. A revista da literatura será desenvolvida em tópicos, a fim de conduzir a uma linha de raciocínio do desenvolvimento desta pesquisa.

\subsection{Etiologia da doença periodontal}

A etiopatogenia da doença periodontal está relacionada a dois grupos de fatores: o hospedeiro susceptível e a presença de bactérias patogênicas. Fatores etiológicos secundários ou de risco como tabagismo, por exemplo, podem facilitar ou acelerar sua progressão.

A maior característica desta doença é ser causada por microrganismos específicos que colonizam os tecidos moles e duros da cavidade oral constituindo uma polimicrobiota altamente organizada sob a forma de um biofilme (SOCRANSKY; HAFFAJEE, 1994; SOCRANSKY et al., 1998; SOCRANSKY; HAFFAJEE, 2005).

Loë et al. em 1965, evidenciaram, em um clássico estudo da literatura, a relevância do biofilme na etiologia das doenças periodontais. Neste trabalho experimental, foi relatada a relação entre o acúmulo de placa e o desenvolvimento 
da gengivite. Indivíduos sadios, apresentando superfícies dentais limpas, suspenderam por certo período de tempo os procedimentos de higiene oral. Desta forma, pôde ser observada a alteração do biofilme em função do tempo, com consequente inflamação gengival.

Para Lindhe (2005), estudos que relacionam o acúmulo de placa com as alterações inflamatórias gengivais indicam a importância da remoção do biofilme para a manutenção da saúde gengival.

Recentemente, Lang, Schätzle e Löe (2009), reportaram um estudo longitudinal com 565 indivíduos do gênero masculino com idade entre 16 e 34 anos no início da pesquisa. Os participantes do estudo foram acompanhados por um período de 26 anos, com o objetivo de se observar a história natural do ínicio da periodontite. Os autores observaram que sítios com sangramento à sondagem apresentaram uma perda de inserção $70 \%$ maior que os sítios não inflamados. Dentes com sítios não inflamados exibiram uma taxa de sobrevivência de 50 anos de $99,5 \%$ enquanto que dentes com sítios inflamados resultaram em uma taxa de sobrevivência de $63,4 \%$. Com base nestes resultados foi concluído que a gengivite representa um importante fator de risco para o desenvolvimento da doença periodontal, com conseqüente perda de inserção e perda do elemento dental. Outras variáveis sistêmicas como fumo e idade têm sido relacionadas à progressão da doença, tendo em vista que nem todos os sítios com gengivite evoluem para periodontite (SCHÄTZLE et al., 2009).

Algumas bactérias presentes nos biofilmes orais têm sido relacionadas com o início e progressão da doença periodontal. Estudos clínicos, microbiológicos e epidemiológicos comprovaram a participação de microrganismos específicos ou combinações de microrganismos na etiologia das periodontites. (LOVDAL et al., 
1958; LÖE; THEILADE; JENSEN, 1965; THEILADE et al. 1966; RUSSEL, 1967; LÖE et al. 1982; SOCRANSKY; HAFFAJEE; 1994; SOCRANSKY et al., 1998; SOCRANSKY; HAFFAJEE, 2005; ARMITAGE, 2010).

Em 1683, Van Leeuwenhoek observou a complexidade da microbiota subgengival por microscopia (SOCRANSKY et al., 1998) e, a partir deste relato, a composição deste ecossistema passou a ser intensamente estudada por meio de microscopia eletrônica, cultura de células, e por técnicas moleculares mais atuais como os métodos que utilizam sondas de DNA.

Com isso, pode-se comprovar a existência de um grande número de espécies bacterianas no biofilme subgengival e estabelecer uma relação mais precisa entre as espécies encontradas com a severidade e as diferentes manifestações da doença periodontal (SOCRANSKY et al., 1998; PASTER et al., 2001; AVILA-CAMPOS; VELASQUEZ-MELENDEZ, 2002; GOMES et al., 2006; COLOMBO et al., 2009; ARMITAGE, 2010; RESCALA et al., 2010). Estima-se que mais de 400 espécies residam nesta área, embora muitas espécies ainda não foram totalmente caracterizadas ou cultivadas (MOORE \& MOORE, 1994; SOCRANSKY et al., 1998).

Alguns autores relataram que a maioria dos microrganismos considerados periodontopatogênicos são Gram negativos, anaeróbios e, menos freqüentemente, microaerófilos (SOCRANSKY, 1977; SLOTS et al., 1978; THEILADE 1986).

Socransky et al. (1998) analisaram, com diagnóstico molecular de DNA, a microbiota subgengival de 185 pacientes, sendo 25 indivíduos com saúde periodontal e os demais, perda de inserção, indicativo da doença periodontal. Foram utilizadas sondas específicas de 40 espécies bacterianas, e os autores observaram interações entre as espécies, formando cinco complexos microbianos no 
ecossistema subgengival. Os diferentes complexos parecem ter distintas associações com a severidade da doença em vários estágios de desenvolvimento do biofilme. Concluíram que a presença de uma bactéria específica está na dependência da presença de pelo menos mais uma bactéria do mesmo complexo.

As bactérias do complexo vermelho, composto pelas espécies Tannerella forsythensis, Porphyromonas gingivalis e Treponema denticola foram fortemente associadas às bolsas periodontais profundas e à presença de sangramento à sondagem. Segundo os autores, a presença destes microrganismos, sugere uma maior destruição tecidual. Outro complexo, o laranja, parece preceder a colonização do complexo vermelho, e tem a característica de ser menos agressivo. Este complexo compreende as espécies Fusobacterium nucleatum, Fusobacterium periodonticum, Prevotella intermedia, Prevotella nigrescens e Parvimonas micra; Eubacterium nodatum, Campylobacter rectus, Campylobacter showae, Campylobacter gracilis, e Streptococcus constellatus (SOCRANSKY et al., 1998).

Ainda de acordo com Socransky et al. (1998), os outros 3 complexos, o amarelo, o verde e o roxo, demonstraram grande associação entre si e menor associação com o vermelho e laranja, e são compostos por diversas espécies consideradas compatíveis com o hospedeiro. Os complexos amarelo e verde foram detectados nos sítios gengivais mais saudáveis, no início da formação da placa. O amarelo é composto por um grupo de estreptococos: S. mitis, S. sanguinis, S. oralis, S. gordonii e S. intermedius.. O complexo verde é formado por Capnocytophaga sputigena, C. gingivalis, C. ochracea, Eikenella corrodens e Aggregatibacter actinomycetemcomitans sorotipo a. O complexo roxo inclui Actinomyces odontolyticus e Veillonella parvula. As espécies de Selenomonas noxia e 
Aggregatibacter actinomycetencomitans sorotipo b não se correlacionaram com outras espécies.

Posteriormente, algumas espécies de actinomicetos (Actinomyces israelii, Actinomyces gerencseriae, Actinomyces naeslundii sorotipos 1 e 2) foram agrupadas no complexo azul (SOCRANSKY; HAFFAJEE, 2002).

Diversos estudos têm demonstrado que as espécies Tannerella forsythensis, Prevotella intermédia, Porphyromonas gingivalis e Aggregatibacter actinomycetemcomitans constituem patógenos fundamentais para o desenvolvimento da periodontite. Outras espécies, como Campylobacter rectus, Peptostreptococcus micros, Fusobacterium nucleatum, Eubacterium nodatum, Streptococcus intermedius e espiroquetas, são apontadas como possíveis patógenos associados à condição de doença (RENVERT et al., 1998; CUGINI et al., 2000; QUIRYNEN et al., 2002; SOCRANSKY; HAFFAJEE, 2002).

O fato de serem encontrados microrganismos periodontopatógenos nos tecidos da cavidade bucal não significa necessariamente o desenvolvimento da doença periodontal (LÖE et al., 1986). Alguns indivíduos podem apresentar apenas uma reação inflamatória nas áreas marginais da gengiva, enquanto outros desenvolvem uma destruição mais severa dos tecidos gengivais, como perda de inserção conjuntiva e osso alveolar.

Normalmente a interação entre a microbiota bucal e o hospedeiro é benigna, não oferecendo riscos para as estruturas de suporte dental (LINDHE, 2005). Segundo Quirynen, 2001, o processo de doença se desenvolve quando há uma quebra do equilíbrio ecológico existente entre a resposta do hospedeiro frente ao ataque microbiano. Um grupo de bactérias pode, ocasionalmente, proliferar ou 
exibir novas propriedades que levem a destruição dos tecidos periodontais. (SOCRANSKY; HAFFAJEE, 2005).

Fatores de proteção do hospedeiro, como epitélio e fluxo do fluido gengival, imunidade celular e capacidade de regeneração celular inatas do organismo podem ser meios que controlam a ação dos possíveis periodontopatógenos (ZAMBON, 1996; ARMITAGE; ROBERTSON, 2009).

De acordo com Lindhe (2005) as reações inflamatórias e imunológicas que um indivíduo desenvolve contra um determinado patógeno e seus produtos tóxicos, como uma forma de defesa, são as características predominantes das doenças periodontais, e podem ser responsáveis por grande parte da lesão tecidual observada nesta patogenia.

Assim, a instituição de medidas terapêuticas tão logo apareçam os primeiros sinais de ínjúria tecidual, pode evitar níveis de destruição mais severos.

\subsection{Antibióticos no tratamento da doença periodontal}

O principal objetivo da terapia periodontal é a biocompatibilização da superfície radicular permitindo o restabelecimento da saúde do periodonto, por meio da eliminação do biofilme dental, tendo em vista que este constitui a principal causa da doença. Quando a terapia utilizada é eficaz em reduzir espécies bacterianas periodontopatogênicas, ocorre a redução da inflamação, a redução da profundidade de sondagem e a adesão epitelial, mantendo níveis de inserção clínica estáveis ao longo do tempo (CUGINI et al., 2000; FERES et al., 2001; CARVALHO et al., 2005; TELES et al., 2006).

O tratamento clássico das periodontites, considerado o padrão ouro, é a raspagem e alisamento radicular (RAR). É um mecanismo eficiente, e consiste na 
remoção mecânica do biofilme e cálculo subgengival, por meio de instrumentos manuais ou ultrasônicos, com consequentes benefícios em relação à composição da microbiota local e nos parâmetros clínicos periodontais. (MOMBELLI et al., 1994; BADERSTEN; NILVEUS; EGELBERG, 1984; SHILOAH; PATTERS, 1994; HAFFAJEE et al, 1997; GREENSTEIN, 2000; KHOSRAVI et al., 2004; CUGINI et al., 2000; CARVALHO et al., 2004;; LÓPEZ, 2006).

Entretanto, em alguns casos a RAR parece não ser capaz de devolver ou manter a saúde periodontal, devido à permanência de certos microrganismos patogênicos como Aggregatibacter actinomycetemcomitans, Porphyromonas gingivalis, Tanerella forsythensis e Prevotella intermédia (SBORDONE et al.1990; SHILOAH et al., 1996; 1998; EDWARDSON et al., 1999; MOMBELLI et al., 2000; PETERSILKA; EHMKE; FLEMMIG, 2002).

Sítios periodontais severamente comprometidos, com bolsas muito profundas e de difícil acesso à instrumentação manual, podem não apresentar uma resposta positiva ao tratamento convencional (MAGNUSSON et al, 1984; RUDNEY et al., 2005).

A capacidade de alguns patógenos penetrarem nos tecidos periodontais e orais, podendo transformar estas áreas em reservatórios de microrganismos, com conseqüente re-infecção do local tratado, foi relatada por alguns autores (ADRIAENS et al., 1988; MÜLLER, LANGE, MÜLLER, 1993; SANDROS et al., 1994; QUIRYNEN et al., 2001; COLOMBO et al., 2006). Fatores sistêmicos modificadores da resposta do hospedeiro também podem estar relacionados ao insucesso do tratamento mecânico.

Sbordone (1990) relatou que a recolonização de bolsas periodontais por determinadas bactérias periodontopatogênicas pode ocorrer 60 dias após a terapia 
mecânica. Desta forma, os benefícios obtidos com a raspagem e alisamento radicular podem ser instáveis a longo prazo (CUGINI, 2000).

Visando a saúde do periodonto, o debridamento periodontal repetido é requerido como forma de manutenção e suporte da terapia periodontal, reduzindo a quantidade de microrganismos patogênicos nos sítios subgengivais. Entretanto, em sítios com menor profundidade de sondagem, a técnica de raspagem e alisamento radicular pode traumatizar o periodonto e causar perda de inserção (PETERSILKA; EHMKE; FLEMMIG, 2002). Diante destes fatos, a instituição de uma terapia coadjuvante no tratamento da doença periodontal pode ser necessária ou fundamental.

A administração de agentes antimicrobianos tem sido empregada como um importante complemento do debridamento mecânico, uma vez que o uso sistêmico ou local de antibióticos pode eliminar ou diminuir patógenos periodontais específicos (SOMAYAJI et al., 1998; HAFFAJEE et al., 2004; HAFFAJEE; PATEL; SOCRANSKY, 2008).

Estudos têm demonstrado que a terapia antibiótica isolada ou associada ao tratamento periodontal convencional promove melhora nos parâmetros clínicos, imunológicos e microbiológicos de diversas enfermidades periodontais (HERRERA et al., 2002; LÓPEZ et al. 2006; MOMBELLI, SAMARANAYAKE, 2004; SIROTTO, 2008).

Sedlacek \& Walker (2007) enfatizaram que a remoção ou desorganização do biofilme dental pela instrumentação mecânica é fundamental para a eficácia dos antibióticos, pois na presença do biofilme os microrganismos podem se tornar mais resistentes. Nestes casos, concentrações mais elevadas de fármaco podem ser necessárias para atingir um adequado efeito antibacteriano. 
O uso sistêmico de antibióticos como coadjuvante da terapia convencional pode atingir concentrações na saliva e no fluido gengival de maneira a atingir patógenos periodontais nos sítios extra-creviculares e também em áreas subgengivais não alcançadas pela instrumentação mecânica (MÜLLER et al.; 1988; EHNKE et al., 2005; PAHKLA et al., 2005).

Entretanto, Johnson et al. (2008) observaram a presença de certas espécies periodontopatógenas junto às células epiteliais após a antibioticoterapia sistêmica com amoxicilina e metronidazol, confirmando a hipótese de recolonização de sítios periodontais por reservatórios bacterianos extra-creviculares.

Mombelli \& Samaranayake (2004) relataram em um artigo de revisão que o uso dos antibióticos sistêmicos pode melhorar parâmetros clínicos e reduzir consideravelmente os microrganismos de bolsas periodontais desde que estes fármacos sejam selecionados de acordo com a microbiota local.

$\mathrm{Na}$ tentativa de estabelecer uma terapêutica periodontal eficaz, muitos antibióticos foram testados. A tetraciclina foi o antimicrobiano mais avaliado dentro da literatura, seguido por seus derivados, a doxiciclina e a minociclina, e outros fármacos como a amoxicilina, a azitromicina, o metronidazol e a associação deste com amoxicilina (LOESCHE et al., 1991; 1993; 1994; GOENÉ et al., 1990; RAMS et al., 1990; GORDON \& WALKER, 1993; PREUS et al., 1995; NG \& BISSADA, 1998; VANDEKERCKHOVE, QUIRYNEN, VAN STEENBERGHE, 1998; RAMBERG et.al., 2001; NOIRI et al., 2003; LÓPEZ et al., 2006; DANNEWITZ et al., 2007; CIONCA et al., 2009; RIBEIRO et al.,2009; MESTINIK et al., 2010; TÜTER et al., 2010).

Nas últimas décadas, estudos que avaliam o uso do metronidazol como auxiliar da terapia periodontal básica têm sido intensificados em decorrência de seus 
efeitos benéficos. (LOESCHE, 1991,1993; FERES et al., 2001; HAFFAJEE, PATEL, SOCRANSKY, 2008; RIZZO et al., 2010).

O metronidazol é um composto sintético, derivado do nitroimidazol, desenvolvido primariamente para ser utilizado como um agente anti-tricomona sistêmico. Sua atividade bactericida, assim como seu uso em Odontologia, foram relatados por Shinn em 1962, ao observar alívio nos sintomas da gengivite úlcero necrosante em uma paciente que estava fazendo uso deste medicamento no tratamento da tricomoníase vaginal, e mais tarde confirmados por Tally et al. (1975), ao descobrir seu potencial contra bactérias anaeróbias.

De acordo com Löfmark, Edlund e Nord (2010), o metronidazol é a droga de escolha para infecções anaeróbias, especialmente por sua eficiência contra estes patógenos, baixas taxas de resistência microbiana e favoráveis farmacodinâmica e farmacocinética, além de apresentar poucos efeitos adversos e baixo custo. Por outro lado, quando utilizado em infecções onde não há evidência de microrganismos anaeróbios, sua ação é insignificante (CLARK et al., 1993).

Quanto ao mecanismo de ação, o metronidazol é um quimioterápico que causa morte celular por interferir na síntese de DNA bacteriano. É bem absorvido quando utilizado por via oral, apresentando potencial para atravessar barreiras teciduais, e dessa forma atingir concentrações semelhantes no plasma, saliva e fluido gengival (BRITT \& POHLOD, 1986; VAN OOSTEN, NOTTEN, MIKX, 1986; PÄHKLA et al., 2005). Sua metabolização ocorre principalmente no fígado, havendo formação de metabólitos como o ácido metabólico e o hidroximetabólito, sendo este último o mais importante clinicamente por sua atividade antimicrobiana.

Algumas bactérias anaeróbias facultativas como Capnocytophaga, Eikenella corrodens, Actinobacillus actinomycetemcomitans, demonstraram baixa 
susceptibilidade ao metronidazol in vitro, embora tenha sido observado que o hidroximetabólito do metronidazol pode aumentar, in vivo, a eficácia clínica desta droga contra as bactérias anaeróbias facultativas (JOUSIMIES et al., 1988).

Segundo LOECHE et al. $(1991 ; 1993)$ o uso do metronidazol sistêmico pode reduzir a necessidade de intervenção cirúrgica em alguns tipos de periodontite.

Em 2001, Feres et al., comparando o efeito de antibióticos sistêmicos, observaram melhores resultados clínicos e microbiológicos com o uso do metronidazol em relação à amoxicilina. De acordo com os autores, o metronidazol foi capaz de reduzir as bactérias dos complexos vermelho e laranja. Por outro lado, espécies consideradas benéficas como Actinomyces, Streptococcus e Capnocytophaga, foram pouco afetadas por este composto.

Rizzo et al., 2010 avaliaram os efeitos do metronidazol na capacidade de modular a resposta imune local desencadeada pelos produtos tóxicos bacterianos, e concluíram que este composto é capaz de reduzir ou inibir a liberação de determinadas citocinas, em especial as interleucinas, as quais têm papel fundamental nos processos inflamatórios e de reabsorção óssea.

Ao instituir uma antibioticoterapia por via sistêmica a um paciente com periodontite, podem ocorrer alguns efeitos adversos, tais como náuseas, vômitos, diarréias, dores abdominais, vertigem, dores de cabeça, gosto metálico ou mesmo manchamento dos dentes (LEVIN-GOLDSTEIN, 1992).

Além disso, o uso sistêmico requer, muitas vezes, a utilização de altas doses do agente antimicrobiano por um longo período de tempo para atingir concentrações adequadas no fluido gengival, possibilitando uma alteração da flora bacteriana e desenvolvimento de microrganismos resistentes. Segundo Tenenbaum et al., (1997) alguns antibióticos necessitam de repetidas administrações para 
produzirem efeitos satisfatórios sobre determinadas bactérias, o que aumenta as chances de desenvolvimento de resistência bacteriana.

Em contraste com a terapia sistêmica de antibióticos, a administração de agentes antimicrobianos diretamente na bolsa periodontal, pode minimizar alguns efeitos colaterais indesejáveis. Quando associados a um sistema de liberação lenta, os antibióticos locais permitem a manutenção de concentrações efetivas de um agente terapêutico somente no local de aplicação por longos períodos. Como vantagem, os riscos dos efeitos adversos e o desenvolvimento de resistência bacteriana são reduzidos (VANDEKERCKHOVE, QUIRYNEN, VAN STEENBERGHE 1998; WILDER, 2003; MOMBELLI \& SAMARANAYAKE, 2004).

AKALIN et al. (2004) ao comparar os efeitos da doxiciclina local e sistêmica em pacientes com periodontite crônica concluíram que a redução na profundidade de sondagem foi mais efetiva nos pacientes que receberam o tratamento local, quando o agente antimicrobiano foi utilizado independente da raspagem e alisamento radicular. Além disso, não foram observados os efeitos colaterais indesejáveis, frequentes na terapia sistêmica.

A aplicação local de agentes farmacológicos deve suprir alguns critérios básicos, tais como: a medicação deve atingir o sítio-alvo e; permanecer em concentração adequada no sítio doente por um período de tempo suficiente para a sua ação (GOODSON, 1989).

Outro aspecto desejável diz respeito à capacidade de adesão desses sistemas de liberação lenta, característica que permite uma manutenção por maior tempo do dispositivo no sítio de ação. Foi demonstrado que alguns polímeros adesivos, tais como o Carbopol $934^{\circledR}$ e a hidroxipropil metilcelulose, são adequados para o uso em preparações destinadas à cavidade bucal (PEDRAZZI, 1999), devido 
à sua habilidade em aderir aos tecidos mucosos, nas condições locais, e liberar o princípio ativo.

A American Academy of Periodontology (2000) classifica os sistemas de liberação de fármaco intrabolsa periodontal de acordo com a duração da liberação do fármaco. São divididos em duas classes: dispositivos de liberação sustentada, que promovem liberação por menos do que 24 horas e os sistemas de liberação controlada, que devem ter uma duração que exceda um dia.

Estes sistemas de liberação de fármaco intrabolsa periodontal têm sido extensivamente pesquisados nos últimos anos na busca pelo melhor tratamento para a doença periodontal. (ESPOSITO et al., 1996; JONES et al., 1997; AWARTANI; ZULQARNAIN, 1998; MAGNUSSON, 1998; KINANE; RADVAR, 1999; RIEP; PURUCKER; BERNIMOULIN, 1999; KIM et al., 2004; JANSSON; BRATTHALL; SODERHOLM, 2003; JANSSON et al., 2004; BONITO; LUX; LOHR, 2005; SATO et al., 2008; LEIKNES et al., 2007; BOGREN et al., 2008; PAOLANTONIO et al., 2008; JANATOVÁ et al., 2009; SING; ROY; CHUMBER, 2009).

\subsection{Sistemas de liberação de fármacos no tratamento da periodontite}

O primeiro sistema de liberação de fármaco para bolsa periodontal foi proposto por Goodson; Haffajee e Socransky (1979). Eles aprisionaram a tetraciclina em tubos de diálise de acetato de celulose com $250 \mu \mathrm{m}$ de diâmetro, sendo que um comprimento apropriado do tubo era inserido na bolsa. No entanto, a liberação do fármaco ocorreu rapidamente, 95\% após 2 horas. Apesar desse modelo não ter sido eficiente em manter a concentração terapêutica por um longo período de tempo, ele serviu de base para o desenvolvimento de outros sistemas de liberação. 
Goodson et al. (1983) avaliaram fibras compostas por outros polímeros (polietileno, polipropileno, policaprolactona, poliuretano, acetato-propionato de celulose e etileno vinil acetato) contendo tetraciclina. O sistema composto com as fibras de etileno vinil acetato proporcionou liberação prolongada por nove dias, sendo comercializado com o nome de Actisite ${ }^{\circledR}$ (Alza Corporation, Palo Alto, USA).

As desvantagens do uso das fibras é o tempo relativamente longo (7-10 minutos/dente) de inserção da fibra, já que ela é empurrada gentilmente e dobrada sobre si à medida que é inserida na bolsa até o completo preenchimento da cavidade (GOODSON, 1994). Há a necessidade de se utilizar cola de cianoacrilato para reter o sistema no interior da bolsa e, por não ser biodegradável, é necessária sua remoção ao final do período de terapia (SOSKOLNE, 1997), o que pode comprometer a adesão do paciente ao tratamento.

Outras duas formas de apresentação dos sistemas de liberação local para tratamento da doença periodontal que vêm sendo bem mais utilizadas são os filmes e os sistemas semi-sólidos ou injetáveis. Os filmes têm como vantagens a possibilidade de controle da dimensão e forma, adequando-os à bolsa a ser tratada; são rapidamente inseridos, com mínimo desconforto ao paciente. Dependendo da espessura e da adesividade do material, os filmes podem permanecer submersos entre a gengiva e o dente, sem qualquer interferência nos hábitos alimentares e higiênicos do paciente (SOSKOLNE, 1997).

Um dos primeiros estudos utilizando um filme como sistema de liberação intra-bolsa foi descrito por Addy et al. (1982), no qual foi utilizado como material filmógeno o metilmetacrilato, tendo como fármacos a tetraciclina a $40 \%$, o metronidazol a $40 \%$ e a clorexidina (10 a 50\%). Os filmes contendo os fármacos avaliados foram comparados em relação ao padrão de liberação in vitro com os 
tubos de diálise. A quantidade do agente liberado foi medida por espectrofotometria. As tiras também foram testadas in vivo em voluntários portadores de periodontite avançada, demonstrando liberação mais lenta do que os tubos de diálise, com boa aceitabilidade por parte dos pacientes. A partir de então, passaram a ser estudados vários polímeros de origem sintética e natural, biodegradáveis ou não. Os não biodegradáveis apresentam como inconveniente a necessidade de remoção após a liberação do fármaco.

Yeung, Newman e Addy (1983) compararam o uso de tiras de resina acrílica com metronidazol a 40\% com irrigações subgengivais de clorexidina a 0,2\%. Foram avaliados os índices de placa, sangramento à sondagem, profundidade de bolsa e retração gengival. Não foram encontradas diferenças significantes entre os grupos, concluindo-se que os regimes foram igualmente eficazes em melhorar a saúde periodontal em um período de três meses.

Em 1984, Addy e Langeroudi observaram, por meio da microscopia de campo escuro, os efeitos na microbiota subgengival que decorriam do uso de tiras de acrílico contendo $40 \%$ de um fármaco, podendo este ser a clorexidina, o metronidazol ou a tetraciclina, todos testados na mesma concentração. As tiras foram deixadas por dois a três dias dentro de bolsas com mais de $6 \mathrm{~mm}$ de profundidade. Os três fármacos produziram efeitos similares, com aumento na proporção de cocos e redução na proporção de microrganismos móveis, sendo que o metronidazol foi mais eficaz que a tetraciclina e a clorexidina na redução de espiroquetas.

Golomb et al. (1984) desenvolveram um filme de etilcelulose adicionado ou não de polietilenoglicol, contendo metronidazol a 10\%, para inserção em bolsas periodontais e examinaram o perfil de liberação in vitro e in vivo. A liberação do 
fármaco foi avaliada por meio de um espectrofotômetro de luz ultravioleta e a atividade microbiológica foi baseada em um microrganismo indicador (Bacteroides fragilis). O estudo demonstrou que o filme de etilcelulose contendo metronidazol foi capaz de uma liberação prolongada do fármaco na bolsa periodontal por três dias.

Newman et al. (1984) observaram o efeito do metronidazol, aplicado em bolsas periodontais, de duas formas: sob a forma de uma solução a $0,5 \%$ em finos tubos de diálise e na forma de pó incorporado à resina acrílica a $40 \%$. Foi notado que as tiras de resina liberaram o medicamento por 14 dias e os tubos de diálise por 24 horas. Concluíram que o uso local de metronidazol, mesmo na forma de $0,5 \%$ nos tubos de diálise, tinha um papel positivo no controle da periodontite crônica.

Wan Yusof et al. (1984) compararam o uso de tubos de diálise, contendo em seu interior uma solução de metronidazol a $0,5 \%$, trocados semanalmente, durante três semanas seguidas, com irrigações subgengivais com uma solução de clorexidina a $0,2 \%$ realizadas diariamente pelo próprio paciente. Ambos os tratamentos foram mantidos por 28 dias. Tanto as irrigações com a clorexidina, quanto os tubos de diálise contendo metronidazol, foram igualmente eficientes em promover uma melhora nos parâmetros clínicos da periodontite por pelo menos 8 semanas após o término do período de aplicação das terapias.

Em 1988, Addy et al., analisaram um dispositivo de resina acrílica contendo clorexidina, metronidazol e tetraciclina quanto ao padrão de liberação em bolsas periodontais. Os resultados obtidos com estes antimicrobianos foram comparados com a raspagem e alisamento radicular, por um período de três meses. Os autores relataram melhoras significativas em vários parâmetros clínicos avaliados, tanto para a terapia medicamentosa quanto para a raspagem e 
alisamento radicular, apesar da magnitude e da duração terem sido maiores com os grupos do metronidazol e da raspagem e alisamento radicular.

Outro sistema de liberação filmógeno disponível no comércio é o Periochip $^{\circledR}$ (Perio Products Ltd., Jerusalem, Israel), o qual apresenta como composição básica, gelatina hidrolisada e glicerina. Esse filme biodegradável possui um efeito de liberação instantânea, sendo observadas concentrações de 2007 g/mL de clorexidina no fluido gengival nas primeiras 2 horas após sua aplicação e concentrações de 1300 a $1900 \mu \mathrm{g} / \mathrm{mL}$ nas próximas 96 horas, seguido de liberação mais lenta nos outros dias (SOSKOLNE et al., 1998). Esse sistema é capaz, considerando a CIM da clorexidina igual a $125 \mu \mathrm{g} / \mathrm{mL}$ (STANLEY; WILSON; NEWMAN, 1989), de proporcionar concentrações terapêuticas do fármaco na bolsa periodontal por uma semana.

Mais recentemente, o acetato de celulose sem qualquer associação mostrou maior eficiência em controlar a liberação de gluconato de clorexidina do que o Periochip $^{\circledR}$. Filmes contendo os AINES (antiinflamatórios não-esteroidais) indometacina e meloxicam liberaram apenas $40 \%$ do fármaco em 5 dias, enquanto o Periochip ${ }^{\circledR}$ liberou $96 \%$ em seis horas, nas mesmas condições de experimentação (ÇETIN et al., 2004).

A administração dos sistemas de liberação semi-sólidos no interior da bolsa periodontal é simples e com o mínimo de desconforto para o paciente no ato da inserção da forma farmacêutica. A natureza fluida da formulação possibilita seu espalhamento por todo o interior da bolsa. No entanto, para que fique retida dentro da bolsa e não seja lavada pelo fluido gengival, a formulação deve possuir uma boa adesividade e/ou passar por mudança de fase, tornando-se mais rígida ou sólida no interior da bolsa (MOMBELLI ; SAMARANAYAKE 2004). 
Os sistemas semi-sólidos podem ser constituídos de géis simples ou emulsionados, contendo ou não microesferas. Algumas formulações na forma de gel foram disponibilizadas comercialmente, como o Periocline ${ }^{\circledR}$ (Sunstar Co. Ltd., Osaka, Japan), gel composto de hidroxietilcelulose, copolímero aminoalquilmetacrilato, triacetina, cloreto de magnésio e glicerina, contendo o fármaco minociclina a $2 \%$. Sua utilização, combinada à raspagem e alisamento radicular, proporcionou resultados clínicos significativamente melhores quando comparados ao grupo controle (NAKAGAWA et al., 1991).

Gel similar comercializado com o nome de Dentomycin ${ }^{\circledR}$ (Lederle Laboratories, UK) apresentou vantagens como adjunto do tratamento não-cirúrgico em termos de melhora no nível de inserção gengival e sangramento à sondagem quando comparado ao Periocline ${ }^{\circledR}$ (GRACA et al., 1997).

Needleman e Watts (1989) testaram o uso de um gel de metronidazol a $1 \%$ em áreas de furca, após a terapia periodontal de manutenção. Dez pacientes com envolvimento de furca classe II ou III foram selecionados para o estudo. Mediuse o sangramento à sondagem e o volume do fluido gengival, além do biofilme subgengival ter sido avaliado por microscopia de campo escuro. Após a terapia de manutenção desses sítios, uma seringa foi usada para aplicar o gel de metronidazol (grupo experimental) ou um gel placebo (grupo controle) nas regiões de furca. Após um e três meses, os sítios foram reexaminados, concluindo-se que o grupo experimental não diferiu do controle, em um nível de significância de 5\%.

Em 1992, foi desenvolvido um gel biodegradável à base de monooleato de glicerol e óleo de sésamo, contendo 25\% de metronidazol (NORLING et al., 1992) e comercializado com o nome de Elyzol $^{\circledR}$ (Dumex-Alpharma, Copenhagen, Denmark). Sua eficácia é questionável, com autores advogando a favor (STOLTZE, 
1992; STOLTZE; STELLFELD, 1992) e outros o demonstrando tão efetivo quanto à raspagem no tratamento da periodontite (AINAMO et al., 1992; KLINGE et al., 1992; PEDRAZZOLI; KILIAN; KARRING, 1992).

Apesar disso, há autores que acreditam que o Elyzol ${ }^{\circledR}$ não traz nenhum benefício quando comparado à raspagem e aplainamento radicular (PALMER; MATTHEWS; WILSON, 1998), provavelmente por ser rapidamente lavado da bolsa periodontal (STOLTZE, 1995).

Outro sistema semi-sólido também disponível comercialmente é o Atridox $^{\circledR}$ (Atrix Laboratories, Fort Collins, CO, USA). Trata-se de gel à base do poliéster biodegradável poli(DL-lactídeo) (PLA), contendo $10 \%$ de hiclato de doxiciclina. Quando administrado no interior da bolsa periodontal, ele se solidifica, liberando o fármaco por um período de 7 dias (YEWEY et al., 1997). O uso do Atridox ${ }^{\circledR}$ resultou em melhora significativa na diminuição da profundidade de sondagem, no nível de inserção e no sangramento à sondagem, podendo ser comparado à terapia mecânica (POLSON et al., 1997).

Pourtaghi et al.(1996) avaliaram a eficácia de 3 antibióticos locais aplicados em bolsas periodontais : fibras de tetraciclina a $25 \%$, gel de minociclina a $2 \%$ e um gel de metronidazol a $25 \%$. Investigaram as respostas do uso destes sistemas na inibição da produção ou inativação das metaloproteinases. Para isso eles monitoraram a quantidade de TIMPS (inibidores teciduais de metaloproteinases) no fluido crevicular gengival em sítios com doença periodontal que não respondiam ao tratamento mecânico convencional, sendo que a maior quantidade de TIMPs corresponderia a uma diminuição de MMPs (metaloproteinases). Cinqüenta e dois pacientes foram divididos em quatro grupos. Um grupo recebeu apenas raspagem e alisamento radicular (RAR) e os outros receberam a RAR e os antibióticos. As 
amostras de fluido gengival foram colhidas antes e depois dos tratamentos, e analisadas por meio do teste ELISA (ensaio imunoabsorbente ligado à enzima). Os resultados mostraram um aumento significante dos TIMPS para os três produtos testados, enquanto que não houve um aumento significante quando foi realizada somente a RAR. Os autores concluíram que o uso de sistemas locais de liberação de fármacos é vantajoso quando comparado à terapia mecânica isolada em alterar os níveis de metaloproteinases no fluido gengival, sendo que estes níveis ficam compatíveis com os padrões de saúde periodontal.

Awartani e Zulqarnain (1998) compararam os efeitos da aplicação do gel de metronidazol a $25 \%$ Elyzol $^{\circledR}$ com a raspagem subgengival. Foram selecionados 13 pacientes, sendo que cada um recebeu simultaneamente, em quadrantes selecionados aleatoriamente, todos os tipos de tratamento: 1) aplicação do gel de metronidazol somente, 2) raspagem subgengival, 3) uma combinação do tratamento mecânico com o gel ou 4) tratamento nenhum (controle). Os resultados obtidos demonstraram que, para o tratamento da periodontite de adulto de moderada a severa, a raspagem subgengival isolada foi tão eficiente quanto à combinação da raspagem com a terapia antibiótica.

Lie, Bruun e Böe (1998) compararam três regimes de tratamento de bolsas periodontais: RAR apenas, RAR associados a um gel de metronidazol a $25 \%$ e raspagem associada à aplicação subgengival de uma pomada de tetraciclina a 3\%. Foram avaliados parâmetros clínicos (profundidade de sondagem, nível de inserção gengival e sangramento à sondagem) e microbiológicos, monitorados após 3 e 6 meses do tratamento. Não foram encontradas diferenças significantes entre o gel de metronidazol e o dispositivo contendo tetraciclina. O tratamento mecânico isolado mostrou-se tão eficaz quanto os regimes em que foi usado um 
antimicrobiano, apesar de ter havido uma tendência a melhores resultados nos sítios tratados com a associação da raspagem aos antibióticos.

Magnusson (1998) realizou uma revisão dos resultados obtidos em vários trabalhos clínicos, nos quais foi usado metronidazol tópico para o tratamento da doença periodontal. O autor comentou as formas de aplicação do metronidazol nesses trabalhos, em filmes, tiras, tubos de diálise e na forma de gel, associados ou não à raspagem e alisamento radicular e ainda citou trabalhos que compararam os efeitos do metronidazol sistêmico ao tópico. Concluiu que concentrações efetivas de metronidazol poderiam ser obtidas e mantidas em bolsas periodontais com formulações para a liberação local e sustentada, as quais poderiam ser biodegradáveis.

Também foi observado nesses estudos clínicos que o efeito do metronidazol de uso tópico era comparável a uma sessão de raspagem subgengival e alisamento radicular, tanto em pacientes nunca tratados como em pacientes em tratamento, efeito observado em parâmetros clínicos e microbiológicos indicativos da doença periodontal. Apesar disso, o autor não sugere a substituição do tratamento mecânico convencional pelo metronidazol porque não há estudos que demonstrem segurança no uso repetido e prolongado desses regimes antibióticos, recomendando o uso desses dispositivos de liberação sustentada de maneira conjunta com terapias cirúrgicas e não-cirúrgicas para o tratamento da periodontite (MAGNUSSON, 1998).

Rudhart et al. (1998) avaliaram os efeitos clínicos e microbiológicos de pacientes apresentando periodontite quando submetidos a um tratamento com um gel de metronidazol a 25\%. Foram selecionados para esse estudo 46 pacientes com doença periodontal inflamatória crônica, de moderada a severa, que haviam recebido terapêutica periodontal sistemática de 6 a 24 meses antes de serem 
incluídos nesse estudo. Cada paciente recebeu RAR em dois quadrantes e nos outros dois restantes recebeu a aplicação do gel de metronidazol apenas. Os tratamentos foram feitos no dia zero e repetidos sete dias depois; amostras subgengivais foram colhidas antes dos tratamentos e nos dias 21, 91 e 175 após o início do estudo. Ambos os tratamentos resultaram em redução significante da profundidade de sondagem após 6 meses quando comparada com os níveis iniciais, mas não foram encontradas diferenças estatisticamente significantes nos parâmetros clínicos e microbiológicos entre a terapêutica mecânica e o antibiótico.

Somayaji et al. (1998) compararam a eficácia de dois antimicrobianos, a tetraciclina e o metronidazol, na redução de microrganismos contidos em bolsas periodontais, usando como meio de liberação tiras de etilcelulose. O estudo envolveu 30 pacientes que receberam raspagem supragengival, sendo que os sítios subgengivais receberam tiras contendo metronidazol, tetraciclina ou apenas um placebo, sem antimicrobiano. Os resultados obtidos com ambas as substâncias foram quase idênticos, com liberação lenta e sustentada dos fármacos por um período de 120 horas, no qual todos os microrganismos foram eliminados. A tetraciclina mostrou uma liberação mais rápida, enquanto o metronidazol necessitou de uma concentração menor para atingir a completa redução da microbiota subgengival

Kinane e Radvar (1999) avaliaram a eficácia de três sistemas de liberação de antimicrobianos disponíveis para o tratamento da periodontite. Foram selecionados 79 pacientes, divididos em quatro grupos: RAR apenas (20 pacientes); RAR associados à aplicação de fibras de tetraciclina a 25\% (19 pacientes); a um gel de minociclina a $2 \%$ (21 pacientes) ou a um gel de metronidazol a $25 \%$ (19 pacientes). Medidas clínicas foram realizadas no início do trabalho e após 6 
semanas, 3 e 6 meses da aplicação dos sistemas. Apesar dos três sistemas terem demonstrado algum benefício sobre a raspagem e alisamento radicular isoladamente, a colocação de fibras de tetraciclina simultaneamente ao tratamento mecânico mostrou a maior redução na profundidade de sondagem, após 6 meses de tratamento.

Palmer, Matthews e Wilson (1999) examinaram se a terapêutica antimicrobiana com metronidazol tópico ou sistêmico poderia melhorar a resposta, em pacientes fumantes e não fumantes, ao tratamento periodontal de raspagem e alisamento radicular. Foram selecionados 28 pacientes fumantes e 56 não-fumantes, distribuídos aleatoriamente em três grupos: 1) RAR + ultra-som, sob anestesia local, 2) RAR + 200 mg de metronidazol sistêmico por 7 dias e 3) RAR + duas aplicações subgengivais de um gel de metronidazol a $25 \%$. Não foram encontradas diferenças na resposta clínica aos três regimes de tratamento após 2 e 6 meses, tanto para fumantes quanto para não-fumantes. Este estudo confirmou que o fator fumo é responsável por uma pior resposta ao tratamento periodontal mecânico, independentemente do uso sistêmico ou tópico de metronidazol.

Griffiths et al. (2000) relataram os resultados de um trabalho bicêntrico, onde foram comparados os efeitos clínicos da RAR à RAR associada à aplicação do gel de metronidazol a $25 \%$ Elyzol $^{\circledR}$, em pacientes com periodontite crônica. Oitenta e oito pacientes no total (43 de um centro e 45 do outro) receberam RAR, sendo que em cada paciente dois quadrantes foram selecionados aleatoriamente para receberem a aplicação do gel. Os parâmetros clínicos avaliados foram a profundidade e sangramento à sondagem e o nível de inserção gengival, registrados ao início do tratamento e após 1, 3, 6 e 9 meses da terapia. Concluíram que a 
associação da RAR ao gel de metronidazol foi superior ao tratamento convencional isolado, sendo essa superioridade mantida por 9 meses.

Stelzel e Florès-de-Jacoby (2000) investigaram o efeito de duas aplicações de um gel de metronidazol a $25 \%$ como terapia auxiliar à raspagem subgengival e alisamento radicular. Foram acompanhados 59 pacientes por um período de 9 meses, nos quais foram monitorados parâmetros clínicos (profundidade e sangramento à sondagem e nível de inserção gengival) e microbiológicos, por meio de microscopia de campo escuro. A terapia consistiu de RAR em todos os quadrantes e duas aplicações do gel de metronidazol, com um intervalo de 7 dias entre as aplicações, em dois quadrantes selecionados aleatoriamente, apenas em sítios com profundidade gengival igual ou maior que $5 \mathrm{~mm}$. Quando foi confrontado o tratamento mecânico convencional associado ao gel de metronidazol com o tratamento mecânico isoladamente, houve uma diferença significante favorável à associação de terapias, porém a melhora foi considerada de pouca relevância clínica.

Gabarra (2002) desenvolveu um dispositivo mimetizador da bolsa periodontal que simula as condições de umidade, temperatura e fluxo do fluido crevicular gengival para avaliar, in vitro, sistemas de liberação lenta de fármacos para o tratamento da periodontite. O dispositivo permitiria um melhor conhecimento do sistema carreador e estudo do perfil de liberação do fármaco, possibilitando ajustes laboratoriais antes do emprego in vivo. Foi adicionado a sistemas carreadores o metronidazol como fármaco-modelo na concentração de 15, 20 e 25\%. Cada formulação foi testada in vitro por 9 a 13 dias, período este que normalmente corresponde ao tempo da terapia com antimicrobianos. As formulações testadas foram capazes de manter a liberação in vitro do metronidazol durante todo 
o período teste, em concentração suficiente para inibir os microrganismos associados à periodontite, sendo que a formulação gel à base de poloxamer (Lutrol ${ }^{\circledR}$ F 127) com $15 \%$ de metronidazol foi a que apresentou o melhor perfil de liberação do fármaco.

Azmak et al. (2002) estudaram os efeitos de um sistema de liberação controlada à base de digluconato de clorexidina nos parâmetros clínicos e nos níveis de MMP-8 no fluido gengival de 20 pacientes com periodontite crônica por um período de seis meses. Em cada paciente foram selecionados dois sítios interproximais de dentes anteriores (com uma distância de 2 dentes entre os sítios) apresentando bolsas periodontais com profundidade entre 6 a $8 \mathrm{~mm}$ e divididos em dois grupos, num desenho experimental tipo split mouth. Um grupo (controle) recebeu apenas RAR, enquanto o outro grupo (teste) recebeu RAR mais o chip de clorexidina. As concentrações de MMP-8 foram analisadas no baseline (tratamento) e repetidas após dois, dez dias, e após um, três e seis meses por meio do ensaio imunofluorométrico (IFMA). Os resultados mostraram que não houve diferença estatística nas médias de profundidade de sondagem, nível de inserção cínica e no índice de placa entre os grupos no baseline, e após 2 e 10 dias. Houve uma melhora significante nos parâmetros clínicos após um, três e seis meses em todos os grupos, sem diferença estatística entre os tratamentos. Entretanto, aos três e seis meses, a redução na profundidade de sondagem e melhora no nível de inserção foi maior no grupo teste (RAR + clorexidina) quando comparada ao grupo controle (RAR). Quanto aos níveis de MMP-8, houve um decréscimo significante nos grupos teste (RAR+ colorexidina) entre o baseline e após um, três e seis meses. Na comparação entre grupos, os níveis de MMP-8 exibiram menores valores estatisticamente significantes quando o chip foi utilizado. Foi concluído que o uso do chip de 
clorexidina associado à terapia mecânica (RAR) promove melhoras nos parâmetros clínicos e nas concentrações de MMP-8 comparado à raspagem e alisamento radicular isolada.

Salvi et al. (2002) compararam os efeitos clínicos e microbiológicos de três sistemas biodegradáveis de liberação sustentada para uso em bolsas periodontais, o Atridox ${ }^{\circledR}$ (polímero reabsorvível contendo doxiciclina), Elyzol ${ }^{\circledR}$ (gel de metronidazol) e PerioChip ${ }^{\circledR}$ (chip de clorexidina). Todos os sistemas demonstraram uma redução significante na profundidade de sondagem, mas o Atridox ${ }^{\circledR}$ levou a um ganho significante no nível de inserção gengival quando comparado ao Elyzol ${ }^{\circledR}$.

Um sistema de liberação intra-bolsa, baseado em microesferas contendo minociclina, comercializado sob o nome Arestin $^{\circledR}$ (OraPharma Inc., Warminster, PA, USA), quando associado à RAR, demonstrou eficácia no tratamento da periodontite (PAQUETTE et al., 2003) e periimplantite (RENVERT et al., 2006).

Jansson, Bratthall e Soderholm (2003) avaliaram os resultados do tratamento de pacientes com periodontite recorrente quando tratados com um gel de metronidazol a 25\%. Foram escolhidos 20 indivíduos de um programa de manutenção de periodontite, mas com doença periodontal recorrente. Após 3 meses da RAR, 40 sítios foram selecionados, 2 em cada paciente, sendo um deles tratado com o gel de metronidazol (teste) e o outro com um gel placebo (controle). As medidas clínicas iniciais e nos retornos incluíram o índice de placa, índice gengival, sangramento e profundidade de sondagem e nível de inserção gengival. O estudo demonstrou que o tratamento com o gel de metronidazol não influenciou na resposta cicatricial de pacientes com doença periodontal recorrente.

Jansson et al. (2004) reportaram um estudo onde 20 pacientes recebiam dois tipos de tratamento, ao mesmo tempo: enquanto uma bolsa periodontal recebia 
um gel de metronidazol a $25 \%$, outro sítio selecionado aleatoriamente recebia um gel placebo. Foram comparados os efeitos do gel contendo metronidazol sobre a microbiota subgengival, utilizando-se para isso apenas três microrganismos representativos nas periodontites: a Porphyromonas gingivalis, Prevotella nigrescens e Actinomyces actinomycetemcomitans. A técnica de identificação microbiológica foi pela reação em cadeia da polimerase (PCR). Os resultados demonstraram que o gel contendo metronidazol não reduziu a ocorrência desses microrganismos específicos.

Perioli et al. (2004) testaram diferentes comprimidos mucoadesivos contendo misturas de derivados de celulose e do ácido poliacrílico, de forma a desenvolver uma nova formulação contendo metronidazol para o tratamento da doença periodontal. O melhor desempenho mucoadesivo e o melhor perfil de liberação in vitro foram alcançados pela formulação contendo a hidroxietilcelulose (HEC) e o poliacrilato Carbomer $940^{\circledR}$, na proporção de 2:2. O comprimido obtido continha $20 \mathrm{mg}$ de metronidazol, liberando o fármaco por 12 horas em concentrações sempre acima da concentração inibitória mínima, necessária para eliminar as bactérias anaeróbias responsáveis pela periodontite. Segundo os autores, a maior vantagem dessa formulação estaria em diminuir a dosagem diária do fármaco em mais de 15 vezes, quando comparada à terapia sistêmica, diminuindo assim os efeitos colaterais e melhorando a colaboração do paciente no tratamento.

Perinetti et al. (2004) compararam os efeitos clínicos e microbiológicos da administração subgengival de dois géis, um de clorexidina a $1 \%$ e outro de metronidazol a $1 \%$, em bolsas periodontais, após o tratamento mecânico (RAR). Foram selecionados 63 indivíduos, 25 homens e 38 mulheres, com periodontite crônica. Eles receberam o tratamento mecânico e instruções de higiene oral, sendo 
que após 3 meses foram divididos em três grupos: um recebeu o gel de metronidazol a $1 \%$, outro o gel de clorexidina a $1 \%$ e um último um gel placebo. Os géis foram aplicados quatro vezes, com intervalos de 7 dias entre as aplicações. Os resultados demonstraram uma eficácia dos tratamentos, tanto com o gel de clorexidina, quanto com o de metronidazol, em produzir benefícios nos parâmetros clínicos e microbiológicos em pacientes com periodontite crônica de moderada a severa. Apesar disso, com ambos os géis não se obteve a erradicação completa de patógenos periodontais.

Sato (2006) testou em um modelo animal (cão) um gel à base de Poloxamer 407, contendo metronidazol a $15 \%$ como agente antimicrobiano com o objetivo de verificar seus efeitos em relação aos parâmetros clínicos e microbiológicos. Foram utilizados seis cães apresentando bolsas periodontais $\geq$ $4 \mathrm{~mm}$ (periodontite induzida), sendo que cada cão recebeu quatro tratamentos em um desenho experimental do tipo split-mouth. Os grupos de tratamento foram: 1) RAR + gel de metronidazol a 15\% (grupo experimental); 2) RAR somente (controle positivo), 3) gel de metronidazol a 15\% (experimental) e 4) nenhum tratamento (NTcontrole negativo). Os parâmetros clínicos (profundidade de sondagem - PS, nível de inserção relativo - NIR e sangramento à sondagem - SS) e microbiológicos foram registrados no baseline, 7, 30 e 90 dias após as terapias. A técnica microbiológica utilizada neste estudo foi a hibridização DNA-DNA checkerboard. Os parâmetros clínicos e microbiológicos não puderam demonstrar diferenças entre os quatro grupos de tratamento. PS e NIR tiveram uma redução significante no período de 90 dias de duração deste estudo. Algumas bactérias analisadas neste estudo demonstraram diferenças significantes nas prevalências ao longo do tempo, nos grupos de tratamento que receberam o gel de metronidazol (RAR+Gel e Gel). 
Somente o SS não demonstrou diferenças em função do tempo. A absorção sistêmica do fármaco foi detectada pela análise do plasma. Nas condições experimentais adotadas neste estudo, não ficou demonstrado que o gel isoladamente ou combinado com a RAR era diferente dos controles RAR e NT.

Neste mesmo estudo, a presença de metronidazol no fluido crevicular gengival foi monitorada pela cromatografia líquida de alta eficiência (CLAE). Os resultados demonstraram que o metronidazol pode ser detectado por até 48 horas após a aplicação do gel no interior das bolsas periodontais, e em níveis bastante baixos (SATO et al., 2008).

Agan, Sonmez e Serdar (2006) avaliaram a eficácia do tratamento não cirúrgico associado a aplicação tópica subgengival de um gel de doxiciclina $\left(\right.$ Atridox $^{\circledR}$ ) por meio da análise dos níveis de MMP-8 em pacientes com doença periodontal crônica e aguda. Quarenta dentes dos pacientes com doença periodontal crônica e 32 dentes de pacientes com doença aguda foram avaliados durante seis meses. Os níveis de metaloproteinase foram avaliados em uma semana, um, três e seis meses, tanto nos grupos controle (RAR), como nos grupos onde foi aplicado o gel (RAR+Doxiciclina). Os autores observaram que houve um declínio significativo nos níveis de MMP-8 em todos os grupos, embora não tenha sido observada diferença significante entre eles.

Com o objetivo desenvolver um sistema biodegradável intra-bolsa periodontal que fosse capaz de ser facilmente inserido no espaço subgengival e liberar concentrações terapêuticas de fármaco por um período prolongado, e em baixa dosagem, evitando efeitos adversos, Ahuja, Ali e Rahman (2006) formularam um dispositivo filmógeno contendo $69,2 \mathrm{mg}$ de cada antibiótico, metronidazol e amoxicilina, 2\% de plastificante dietil ftalato e $750 \mathrm{mg}$ de PLGA - poly (L-lactide-co- 
glycolide acid). O dispositivo foi testado em relação a vários parâmetros de avaliação, como variações de peso, uniformidade do conteúdo, $\mathrm{pH}$ da superfície e quanto ao perfil de liberação in vitro e in vivo. Foi demonstrado que os filmes promoveram liberação in vitro do fármaco por 16 dias, e in vivo foram observadas concentrações dos fármacos durante o período de análise do padrão de liberação. Os filmes foram capazes de inibir o crescimento da maioria das espécies testadas, evidenciando um elevado espectro de ação e também um efeito sinérgico sobre a espécie E. limosum, considerada resistente ao metronidazol em estudos anteriores. Foi concluído que este sistema foi eficiente quanto ao padrão de liberação e promove benefícios em relação à terapia sistêmica, devido às baixas doses de fármaco utilizadas.

Leiknes et al. (2007) reportaram um estudo no qual foi avaliado um gel de metronidazol a $25 \%$ como coadjuvante do tratamento periodontal convencional. Vinte e um pacientes em fase de manutenção do tratamento periodontal e com sintomas de inflamação crônica recorrente, participaram do estudo. Em cada paciente foram selecionados dois sítios contralaterais apresentando bolsas periodontais > que $5 \mathrm{~mm}$, sendo que cada sítio recebeu um determinado tratamento: (RAR somente - controle; e RAR associada ao gel de metronidazol a $25 \%$ - teste) num desenho experimental tipo split-mouth. Foram realizadas avaliações dos parâmetros clínicos e microbiológicos antes do tratamento (baseline) e após três e seis meses do tratamento. Ambos os tratamentos apresentaram redução significante na profundidade de sondagem (1,9 e 1,8mm), ganho de inserção clínica (1,6 e 1mm) e redução no sangramento à sondagem, entretanto, não foram observadas diferenças significantes entre os grupos. Os autores concluíram que o gel de 
metronidazol a $25 \%$ não promove melhores resultados em relação à raspagem e alisamento radicular no tratamento de pacientes com doença periodontal recorrente.

Bogren et al. (2008) avaliaram o efeito nos parâmetros clínicos e microbiológicos de repetidas aplicações de um gel de doxiciclina em bolsas periodontais de 128 pacientes em fase de manutenção da terapia periodontal. Os indivíduos foram divididos aleatoriamente em dois grupos de acordo com o tratamento: grupo teste - RAR associado ao gel de doxiciclina e grupo controle somente RAR. O gel foi aplicado no baseline, e a aplicação repetida após um ano e após 2 anos. Foram encontradas diferenças significantes nos parâmetros clínicos e parâmetros microbiológicos entre os grupos, em favor do gel de doxiciclina. Embora a aplicação do gel tenha sido benéfica, as repetidas aplicações deste sistema associado à RAR não promoveram qualquer vantagem em relação à terapia mecânica isolada.

Em um estudo com 116 pacientes portadores de periodontite de moderada a severa Paolantonio et al. (2008) compararam os efeitos microbiológicos e clínicos de um dispositivo de liberação lenta contendo clorexidina. Cada sítio recebeu um tipo de tratamento: RAR - grupo controle; e RAR associada ao chip de clorexidina (Periochip ${ }^{\circledR}$ ) - grupo teste. Foi realizado o cultivo para a contagem total de bactérias e a análise de oito espécies periodontopatogências foi realizada por meio do teste PCR. Após três e seis meses houve uma redução significante na profundidade de sondagem e nível de inserção relativa nos dois grupos $(p<0,01)$. Entretanto, a redução na profundidade de sondagem foi maior no grupo que recebeu o chip de clorexidina. Concluiu-se que o uso do chip de clorexidina associado a raspagem e alisamento radicular promove resultados satisfatórios e superiores a RAR isolada. 
Com o objetivo de avaliar a eficácia e a segurança de um antibiótico para uso tópico, Gopinath et al. (2009) selecionaram 15 pacientes com periodontite crônica e compararam os resultados clínicos da terapia periodontal básica isolada com a associação desta à um gel de doxiciclina disponível comercialmente $\left(\right.$ Arestin $\left.^{\circledR}\right)$. Em cada paciente foram identificados quatro sítios apresentando bolsas periodontais entre 5 a $8 \mathrm{~mm}$, sendo que dois sítios foram incluídos no grupo controle (RAR) e dois (contralaterais) foram incluídos no grupo teste (RAR+ gel ). Os índices de placa, sangramento à sondagem e profundidade de bolsa foram mensurados no baseline e aos 30, 90 e 180 dias. Embora tenha sido observada redução significante nos parâmetros clínicos em ambos os grupos, o grupo no qual o gel foi utilizado apresentou melhores resultados estatisticamente significantes, evidenciando os benefícios da associação do gel de doxiciclina com a RAR.

Singh, Roy e Chumber (2009) compararam dois sistemas de liberação de fármacos, um contendo metronidazol e outro contendo tetraciclina como adjuntos da terapia mecânica, e avaliaram sua eficácia clínica e seus efeitos na microbiota subgengival. Cento e vinte pacientes com periodontite crônica que apresentassem no mínimo duas bolsas periodontais com profundidade $\geq 5 \mathrm{~mm}$, foram divididos para três grupos: grupo A (raspagem + tetraciclina), grupo B (raspagem + metronidazol) e grupo C ( apenas raspagem). A presença das espécies patogênicas Aggregatibacter actinomycetemcomitans, Tannerella forsythensis, Porphyromonas gingivalis foi detectada por PCR. Os resultados demonstraram uma diferença pequena, mas significante, na profundidade de sondagem quando os dispositivos de liberação foram utilizados em comparação a terapia mecânica isolada. Além disso, foi observada uma melhora nos parâmetros microbiológicos nos grupos A e B, enquanto que no grupo $\mathrm{C}$ a redução na contagem de bactérias foi menor. $\mathrm{O}$ uso 
local do metronidazol e da tetraciclina promoveram melhores resultados quando comparados à RAR isolada.

Shifrovitch et al. (2009), desenvolveram sistemas filmógenos contendo metronidazol para uso em bolsas periodontais compostos por 50/50 PDLGA - poly (DL-lactide-co-glycolide), 75/25 PDLGA, e PDLLA - poly (DL-lactic acid). Os efeitos destes copolímeros foram investigados em relação ao padrão de liberação do fármaco, crescimento de células e inibição bacteriana. Quando o filme contendo $10 \%$ em peso de metronidazol foi utilizado resultou em uma diminuição significante na viabilidade bacteriana por vários dias. Os filmes apresentaram uma adequada liberação, boa biocompatibilidade e capacidade de inibição bacteriana, podendo ser de grande utilidade no tratamento das doenças periodontais.

Com base nestes trabalhos, a instituição de agentes antimicrobianos locais como adjunto da terapia mecânica poderia proporcionar avanços no tratamento das diversas formas de periodontite. Entretanto, a composição ideal do sistema a ser utilizado bem como um protocolo que regularize sua utilização, ainda não foram totalmente estabelecidos, sendo necessários mais estudos que comprovem seus reais benefícios. 
3 Proposição 


\section{PROPOSIÇÃO}

O propósito deste estudo foi avaliar um dispositivo polimérico de liberação intrabolsa periodontal à base de um gel contendo metronidazol a $15 \%$ para o tratamento adjuvante da periodontite crônica em pacientes adultos, por meio do (a):

1) Monitoramento por meio da Cromatografia de Alta Eficiência (CLAE), das concentrações de metronidazol no fluido gengival colhido de pacientes que receberem o gel de metronidazol;

2) Avaliação dos efeitos dos tratamentos realizados nos pacientes pela análise de indicadores clínicos (profundidade de sondagem e nível clínico de inserção) por meio de sonda computadorizada;

3) Avaliação dos efeitos dos tratamentos realizados nos pacientes pela análise microbiológica utilizando o método da hibridização DNA Checkerboard. 
4 Material e Métodos 


\section{MATERIAL E MÉTODOS}

Foi realizado um estudo clínico para testar a hipótese de que o uso associado do sistema de liberação local (gel) à raspagem e alisamento radicular (RAR) é superior à terapia RAR isolada.

Este estudo foi apreciado e aprovado pelo comitê de ética da FORP-USP (Processo $\mathrm{n}^{\circ}$ 2006.1.1422.58.5). Os indivíduos selecionados para a pesquisa foram informados verbalmente e por escrito sobre o objetivo e todas as etapas do estudo, além dos riscos e benefícios provenientes das terapias a serem utilizadas (Anexo 1). A participação no estudo foi voluntária e os participantes assinaram um termo de consentimento livre e esclarecido, autorizando a utilização dos dados da pesquisa, de acordo com a Resolução n 196/96 das Diretrizes e Normas do Conselho Nacional de Saúde (Anexo 2).

\subsection{Seleção dos Pacientes}

Para a seleção dos indivíduos participantes da pesquisa foi realizada uma triagem prévia em cerca de 200 pacientes, por meio de anamnese e de um exame clínico, utilizando uma sonda periodontal convencional tipo OMS. A seleção foi realizada por duas profissionais, auxiliadas por alunos de iniciação científica, sob a supervisão do coordenador do projeto. Foram selecionados pacientes de ambos os sexos que estavam à espera de tratamento periodontal na clínica de especialização da Faculdade de Odontologia de Ribeirão Preto - USP. Os critérios de inclusão no estudo foram: 
- pacientes com periodontite crônica, com nível clínico de inserção igual ou maior que $6 \mathrm{~mm}$ em dois ou mais dentes e profundidade de sondagem igual ou maior que $5 \mathrm{~mm}$ em um ou mais sítios periodontais (MACHTEl et al., 1992);

- faixa etária de 35 a 70 anos;

- não ter feito uso de antibióticos há pelo menos 3 meses;

- ausência de histórico de alergia aos componentes presentes na formulação a ser avaliada.

Os critérios de exclusão no estudo foram:

- doença cardiovascular grave;

- diabetes;

- problemas relacionados à farmacocinética, como nefropatias, hepatopatias, etc.

- gestante;

- fumante;

\subsection{Delineamento experimental}

O tamanho da amostra foi calculado por uma profissional com experiência em cálculos estatísticos, com o auxílio do software PASS 2005 (NCSS, Kaysville, EUA). Foi selecionado o parâmetro clínico nível clínico de inserção como variável primária para a determinação da progressão da periodontite (PAGE; DEROUEN, 1992; PIHLSTROM, 1992) e também para a determinação do $\mathrm{N}$ amostral.

Para a comparação de dois grupos independentes (RAR e RAR+gel) com medidas repetidas realizadas em quatro tempos $(\mathrm{T}-7=$ baseline, $\mathrm{T} 7=7$ dias, $\mathrm{T} 30=$ 1 mês e T 90 = 3 meses), considerando-se um desvio-padrão de 1,26 entre indivíduos e 0,89 nas medidas intra-indivíduo (valores dos desvios estimados a partir 
do observado no estudo de Sato, 2006), com poder estatístico (power) igual a 84\% para o fator grupo, e 96\% para o fator tempo e interação grupo x tempo, com nível de significância igual a 5\%, e magnitude do efeito (effect size) de 0,79 para o fator grupo, e 1,12 para o fator tempo e para a interação grupo $x$ tempo, deveria haver 8 indivíduos por grupo, totalizando 16 pacientes no estudo.

Considerando-se a possibilidade de desistências de pacientes no estudo, foram selecionados 10 pacientes por grupo, totalizando 20 sujeitos na pesquisa. No decorrer do trabalho, cinco pacientes saíram voluntariamente do estudo, sendo necessária a seleção de mais um paciente para completar o $\mathrm{N}$ amostral mínimo requerido. Portanto para este estudo foram avaliados 16 pacientes, os quais foram divididos aleatoriamente (sorteio) em dois grupos, a saber:

- Grupo 1 - raspagem e alisamento radicular (RAR) - controle ativo;

- Grupo 2 - RAR + gel de metronidazol - experimental

A avaliação clínica dos pacientes foi realizada por meio do monitoramento das concentrações do metronidazol liberado no fluido gengival a partir do gel testado, e dos efeitos dos tratamentos nos pacientes com doença periodontal crônica, com base nos indicadores clínicos e microbiológicos associados às periodontites. Em cada paciente, dois dentes com profundidade de sondagem $\geq 5$ $\mathrm{mm}$ de profundidade foram selecionados a partir de um exame periodontal. Os indivíduos receberam os tratamentos determinados nos dois grupos anteriormente descritos e tiveram o monitoramento dos indicadores citados, nos seguintes tempos: sete dias antes do tratamento, e, sete, trinta e noventa dias após o tratamento. $\mathrm{O}$ protocolo experimental estabelecido está descrito a seguir: 
I. Preparo inicial dos pacientes: raspagem supragengival

II. T -7 (baseline ) = Sete dias antes do tratamento: exame periodontal de todos os sítios (avaliação dos parâmetros clínicos profundidade à sondagem e nível clínico de inserção), colheita do biofilme subgengival, e estocagem das amostras;

III. T 0 = tratamento: Raspagem e alisamento radicular (Grupo 1) e Raspagem e alisamento radicular seguida pela aplicação do gel de metronidazol (Grupo 2);

IV. $\mathrm{T} 7, \mathrm{~T} 30$ e T 90 = Sete, trinta e noventa dias após o tratamento: exame periodontal, colheita do biofilme subgengival, e estocagem das amostras;

V. Realização dos ensaios laboratoriais

\subsection{Preparo do gel}

A formulação do gel foi desenvolvida no trabalho de Gabarra (2002) e modificada no projeto FAPESP 04/09545-0, sendo descrita no trabalho de Sato (2006). O produto básico é um gel à base do poloxamer 407, polímero registrado como Pluronic $^{\circledR}$ F 127 ou Lutrol ${ }^{\circledR}$ F 127 (Basf Aktiengesellschaft, Ludwigshafen, Germany; lote: WPHY541F). O Lutrol ${ }^{\circledR} \mathrm{F} 127$ tem a propriedade física de manter-se na forma líquida quando resfriado à temperatura de $5{ }^{\circ} \mathrm{C}$ e consistência adequada para aplicação com uma seringa, tornando-se um gel a $37^{\circ} \mathrm{C}$ (temperatura do corpo humano). Constitui-se de um copolímero de duas fases: a fase $\mathrm{A}$, com até $70 \%$ de oxietileno e a fase B, com $30 \%$ de oxipropileno. É um surfactante não-iônico, biocompatível, antiespumante, solúvel em meio líquido, com capacidade de alterar sua forma física de líquido (em torno de $5{ }^{\circ} \mathrm{C}$ ) para semi-sólido, em temperaturas mais elevadas. 
A técnica de preparação do gel foi realizada por meio da adição de $30 \%$ de Lutrol $^{\circledR} \mathrm{F} 127$ à água a uma temperatura de $5{ }^{\circ} \mathrm{C}$, mantendo-se o recipiente parcialmente imerso em banho de gelo, para que fosse mantida a temperatura e a forma líquida do gel. O processo foi realizado sob agitação lenta e constante até total homogeneização da mistura, por meio de um agitador mecânico (Figura 1). Em seguida, esta foi levada a uma câmara fria $\left(5^{\circ} \mathrm{C}\right)$ durante 4 a 5 dias para eliminação das bolhas de ar incorporadas durante o processo e ali permaneceu conservada até o momento do uso.

Antes do uso, ao gel foi incorporado o metronidazol (Formil Química Ltda., Jandira - SP, Brasil, FMT 25.61.034.116) como agente antimicrobiano a uma concentração de 15\%, concentração esta determinada também por Gabarra (2002) como a mais adequada em termos de perfil de liberação. Também foi adicionado o conservante metilparabeno (Nipagin,Labsynth, Diadema - SP, Brasil, lote:106509), para evitar a deterioração do gel, e propilenoglicol (Labsynth, Diadema - SP, Brasil, lote:124934), como veículo. A composição do gel está apresentada na Tabela 1.

O gel foi preparado pelo farmacêutico José Orestes Del Ciampo com o suporte do Laboratório de Pesquisa e Desenvolvimento Farmacotécnico (LPDF), Departamento de Ciências Farmacêuticas da Faculdade de Ciências Farmacêuticas de Ribeirão Preto - USP. Esse laboratório, sob a supervisão do Prof. Dr. Osvaldo de Freitas, vem trabalhando na pesquisa e desenvolvimento de sistemas de liberação de fármacos para administração na cavidade oral. 
Tabela 1. Composição do gel de metronidazol avaliado.

\begin{tabular}{lr}
\hline \hline \multicolumn{1}{c}{ Componentes } & Concentração (\%) \\
\hline \hline Metronidazol & 15,00 \\
Poloxamer 407 (Lutrol ${ }^{\circledR}$ F 127) & 30,00 \\
Propilenoglicol & 5,00 \\
Metilparabeno & 0,15 \\
Água destilada qsp & 100,00 \\
\hline \hline
\end{tabular}
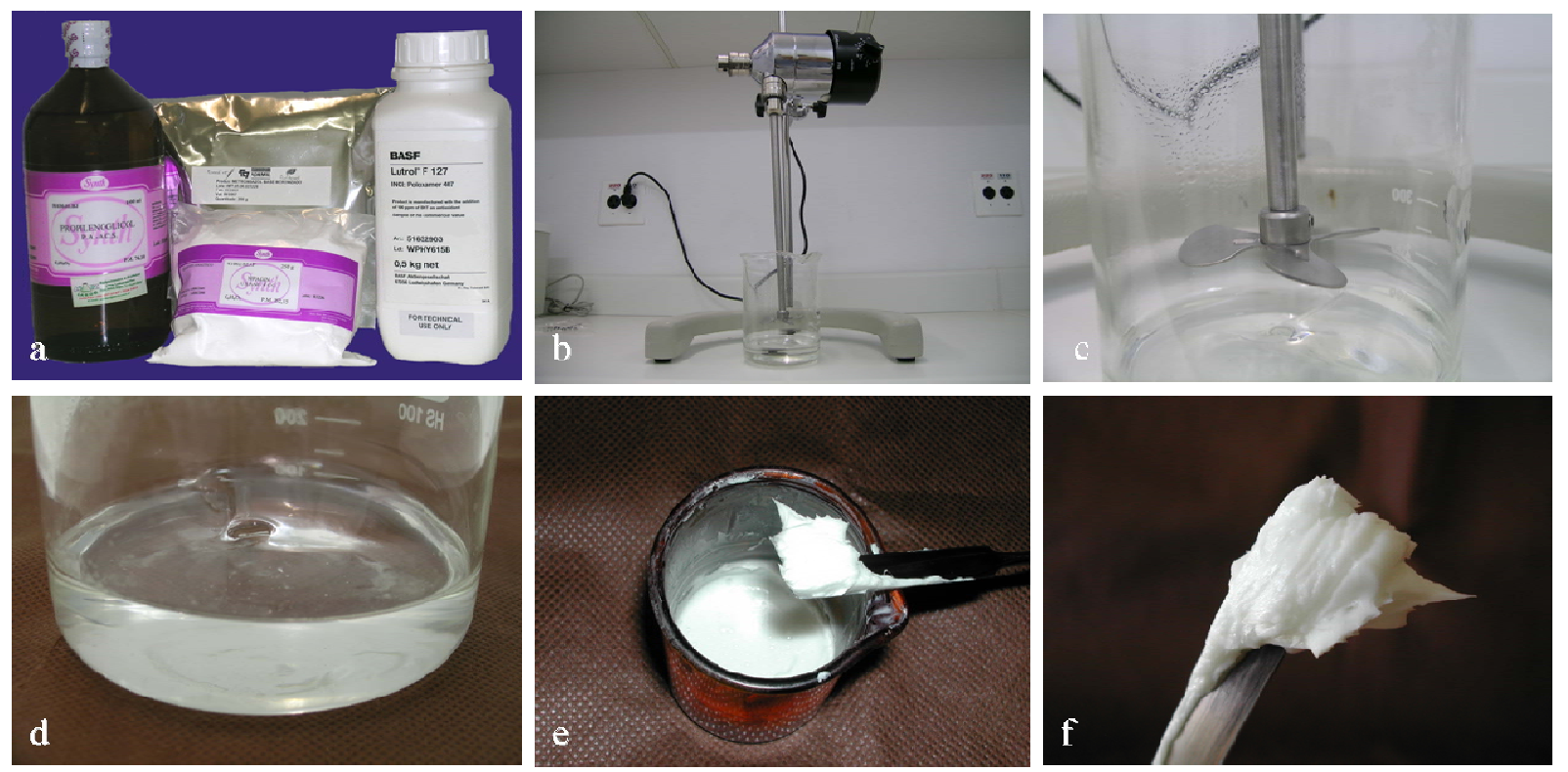

Figura 1. Preparo do gel: a) Componentes do gel; b), c) e d) Agitação e homogeneização dos componentes; e) incorporação do metronidazol na mistura; f) consistência do gel após o preparo. 


\subsection{Preparo inicial dos pacientes}

Após a seleção dos participantes do trabalho, iniciou-se o preparo prévio dos mesmos para o estudo, que consistiu de raspagem supragengival com ultrassom e profilaxia profissional, com o intuito de regularizar as superfícies dos dentes para evitar erros durante a inserção da sonda periodontal. Os voluntários também receberam orientações de higiene bucal. Terminada esta etapa, os indivíduos foram distribuídos nos dois grupos avaliados - Grupo 1 (RAR) e Grupo 2 $(\mathrm{RAR}=$ gel de metronidazol $)$, para receberem os respectivos tratamentos.

\subsection{Tratamento dos pacientes}

Os tratamentos dos pacientes consistindo de raspagem e alisamento radicular (Grupo 1) ou raspagem e alisamento radicular mais aplicação do gel (Grupo 2) foram realizados por duas profissionais capacitadas para esta finalidade, sete dias após o exame clínico-periodontal inicial ( $\mathrm{T}$-7, baseline).

Os pacientes do Grupo1 receberam apenas o tratamento periodontal básico (raspagem e alisamento radicular), o qual foi realizado em uma única sessão. Inicialmente era realizada a raspagem de todos os dentes com ultrassom, e em seguida, os dois dentes selecionados a partir do exame periodontal inicial ( $T$-7, baseline), recebiam raspagem e alisamento radicular com o auxílio de curetas Gracey (Hu-friedy Mffg, Co., Chicago, IL, USA) de numeração correspondente aos dentes avaliados. O biofilme supra e subgengival era removido por meio de curetas de Gracey. A cureta era introduzida até o fundo da bolsa periodontal, inicialmente sem contato da lâmina do instrumento com a parede radicular. Em seguida, a lâmina era colocada em contato com a raiz e então foram realizados movimentos de 
raspagem na superfície radicular por toda a circunferência do dente. O procedimento era executado até a obtenção de uma lisura na superfície radicular.

Os pacientes do Grupo 2 tiveram os mesmos procedimentos de raspagem e alisamento radicular descritos para o Grupo1, e em seguida o gel de metronidazol foi aplicado nos sítios determinados (dois sítios por paciente). Para a introdução do gel nas bolsas periodontais foram utilizadas cânulas endodônticas de aspiração, sem bisel, tamanho 40×10. Estas eram acopladas a seringas descartáveis com capacidade para $5 \mathrm{~mL}$. Os frascos contendo o gel de metronidazol eram mantidos em gelo e no momento do uso, o gel era inserido na seringa. Após isolamento relativo, este era aplicado lentamente dentro das bolsas até o seu completo preenchimento (Figura 2). O excesso era removido cuidadosamente com auxílio de um explorador e uma gaze esterilizada.
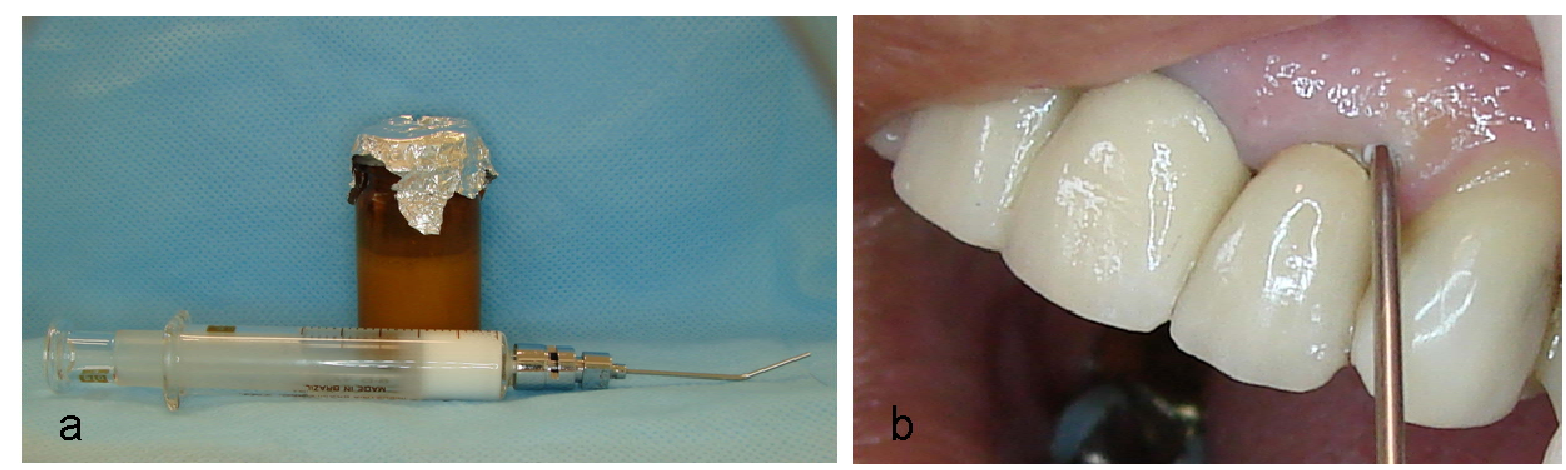

Figura 2. a) Gel de metronidazol e seringa para aplicação nos sítios selecionados; b) Aplicação do gel de metronidazol a 15\% na bolsa periodontal.

\subsection{Monitoramento das concentrações de metronidazol no fluido gengival}

O monitoramento das concentrações de metronidazol foi realizado com a finalidade de avaliar o tempo de permanência deste fármaco dentro das bolsas periodontais. 


\subsubsection{Colheita das amostras de fluido gengival para quantificação do metronidazol}

Logo após a aplicação do gel nos sítios determinados e remoção dos excessos, era realizado o isolamento relativo do local e o fluido gengival era colhido com tiras de papel absorvente (PerioPaper ${ }^{\circledR}$, Oraflow Inc., Plainview, USA), sendo que, para cada bolsa periodontal duas tiras de papel absorvente eram utilizadas, de maneira consecutiva, por 10 segundos (Figura 3). Estas eram inseridas cuidadosamente na bolsa periodontal e o volume colhido do fluido gengival em cada tira de papel era quantificado por meio do aparelho Periotron ${ }^{\circledR} 8000$ (Oraflow Inc., Plainview, USA), Este equipamento eletrônico é utilizado para determinação de pequenos volumes de fluidos (Figura 4).

Após a determinação do volume de fluido gengival absorvido nas tiras de papel com o auxílio do Periotron ${ }^{\circledR} 8000$, os PerioPapers ${ }^{\circledR}$ eram colocados em microtubos com $0,5 \mathrm{~mL}$ da fase móvel utilizada no cromatógrafo, composta de uma mistura metanol:água (30:70 v/v). As amostras eram mantidas sob refrigeração a 4 ${ }^{\circ} \mathrm{C}$ até o momento do processamento para extração do metronidazol presente nas tiras de papel. 


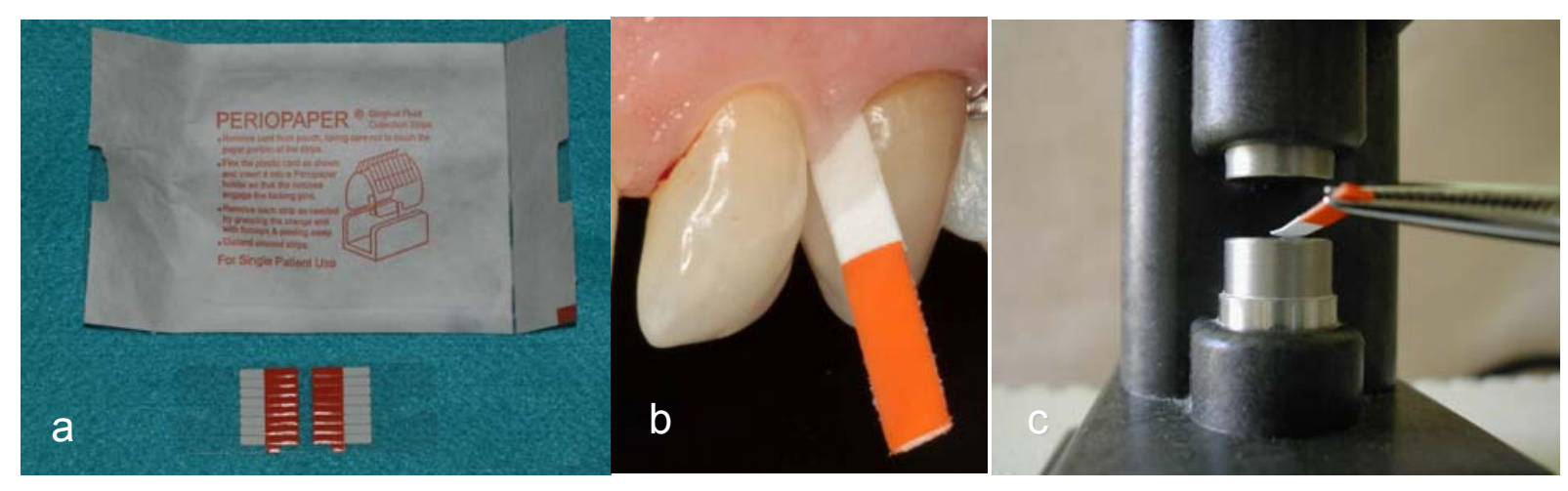

Figura 3. a) Tiras de papel filtro (PerioPaper ${ }^{\circledR}$ ) utilizadas para a colheita do fluido gengival; b) Colheita do fluido gengival com o PerioPaper ${ }^{\circledR}$; c) PerioPaper ${ }^{\circledR}$ sendo disposto entre as pinças do aparelho para quantificação do volume de fluido gengival.

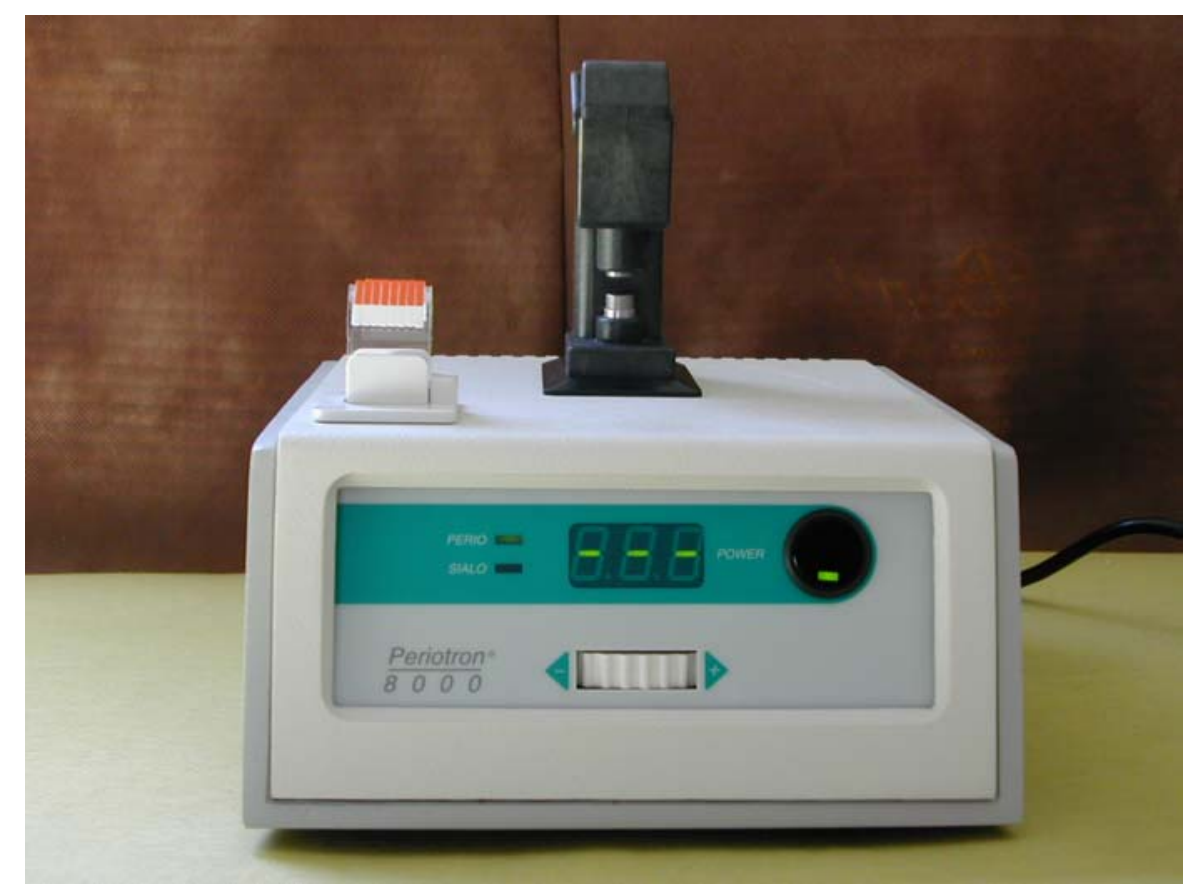

Figura 4. Aparelho Periotron ${ }^{\circledR} 8000$ utilizado para a quantificação dos volumes de fluido gengival. 
Como as amostras de FCG tinham volumes diferentes, da ordem de microlitros, para permitir que todas as amostras usassem um denominador comum para a obtenção da média das concentrações obtidas, os volumes obtidos em cada amostra foram usados para se calcular as concentrações do metronidazol no volume de um mililitro de FCG, padronizando todos os resultados da dosagem do metronidazol na unidade $\mu \mathrm{g} / \mathrm{mL}$ (microgramas de metronidazol por mililitro de FCG).

A colheita das amostras de fluido gengival foi realizada imediatamente após a aplicação do gel, e em intervalos de tempo de $1 \mathrm{~h}$ e $48 \mathrm{~h}$, para se verificar o tempo que o gel permaneceu nas bolsas. As amostras foram analisadas de acordo com metodologia analítica previamente desenvolvida por Sato (2006).

\section{Calibração do Periotron}

Um procedimento de calibração era realizado previamente ao uso do Periotron ${ }^{\circledR}$ para todas as colheitas de FCG realizadas no mesmo mês. Para isso, volumes conhecidos de soro sangüíneo humano, conforme a recomendação do fabricante eram aplicados por meio de uma seringa com capacidade para $1 \mu \mathrm{L}$ (mod. 7001, Hamilton, Reno, USA) nas tiras de papel absorvente (PerioPapers $®$ ), com volumes partindo de $0 \mu \mathrm{L}$ até $0,7 \mu \mathrm{L}$, com intervalos de $0,1 \mu \mathrm{L}$ entre os volumes, três repetições por volume medido. Uma curva de calibração foi construída a partir dos escores que o aparelho determina para um dado volume dispensado no PerioPaper®. No presente estudo, a curva de calibração foi construída com o auxílio do programa NCSS - Number Cruncher Statistical System (HINTZE, 2006) por meio de uma regressão polinomial de quarta ordem, modelo matemático preconizado pelo fabricante e método que fornece maior precisão (CHAPPLE et al., 1999) do que o software Periotron Professional, programa fornecido pelo próprio fabricante. Por 
meio dessa curva de calibração, os volumes desconhecidos das amostras foram obtidos por uma interpolação, convertendo-se os escores que o aparelho fornece em volumes de fluido gengival. A Fig. 5 representa a curva de calibração utilizada para uso do Periotron $®$ e dos PerioPapers $®$ neste estudo.

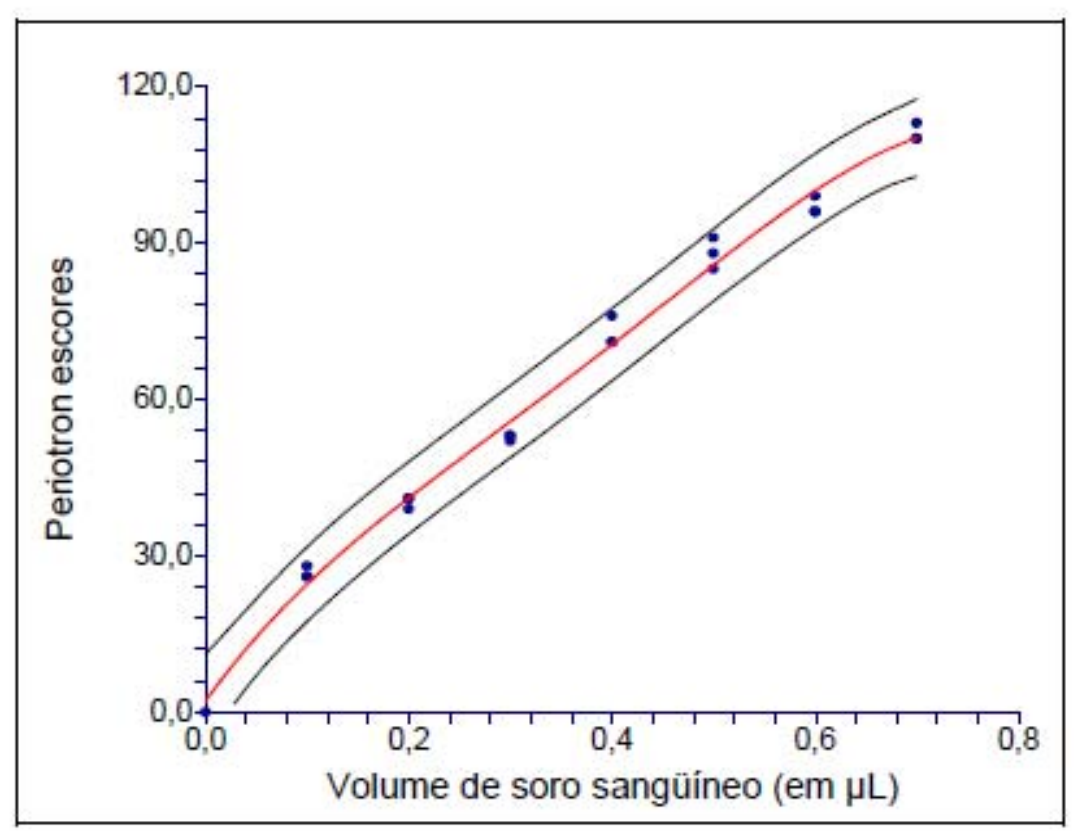

Figura 5. Curva de calibração do Periotron ${ }^{\circledR}$ construída para a determinação do volume de amostras de fluido gengival colhidas com PerioPaper ${ }^{\circledR}$

\subsubsection{Determinação das concentrações de metronidazol nas amostras por}

\section{CLAE}

A quantificação de metronidazol nas bolsas periodontais, foi realizada pelo ensaio de Cromatografia líquida de alta eficiência (CLAE), no Laboratório de Controle de Qualidade do departamento de Ciências Farmacêuticas da Faculdade de Ciências Farmacêuticas de Ribeirão Preto - USP, pelo químico José Roberto Jabor, sob a supervisão da Profa. Dra. Maria José Vieira Fonseca. 


\subsubsection{Processamento das amostras para análise pela CLAE}

Um ensaio prévio foi realizado no trabalho de Sato (2006) para avaliar a quantidade de metronidazol que podia ser recuperada das tiras de papel absorvente, determinando-se assim se havia perda do fármaco por ficar alguma quantidade dele aderida aos PerioPapers ${ }^{\circledR}$. A taxa de recuperação do fármaco conseguida com esse método de colheita foi de $97,92 \%$ em média, concluindo-se que, para o metronidazol, existe uma extração quase que total do fármaco das tiras de papel absorvente.

O método cromatográfico foi validado de acordo com Luattrocchi, Andrizzi e Laba (1992) e para as condições experimentais utilizadas neste estudo algumas análises foram realizadas por Sato (2006) para confirmar a validação da metodologia para a dosagem do metronidazol pela cromatografia líquida de alta eficiência (CLAE).

Para este estudo foi utilizado um cromatógrafo da marca Shimadzu (Shimadzu Corporation, Tokyo, Japão), modelo LC-10AT, acoplado a um detector UV visível modelo SPD-10A e a um integrador C-R6A. Este equipamento está apresentado na Figura 6, com os números descrevendo seus componentes.

Os microtubos contendo a fase móvel (mistura de metanol:água) e o PerioPaper $^{\circledR}$ foram agitados em agitador de tubos na velocidade máxima por 2 minutos. Em seguida, o líquido contido no microtubo era injetado no cromatógrafo com o auxílio de uma seringa (mod. 7001, Hamilton, Reno, USA) para a determinação da concentração do metronidazol que dessorveu da tira de papel absorvente para o meio de dissolução. O conteúdo de cada microtubo contendo a amostra de fluido gengival passou por uma membrana para filtração (Millex ${ }^{\mathrm{TM}}$ LCR, 0,45 m, 13 mm, Millipore, São Paulo, Brasil) antes de ser injetado no cromatógrafo. 
As condições cromatográficas foram as seguintes:

- fase móvel: (30:70 v/v); essa proporção na mistura foi determinada como a mais adequada por Gabarra (2002);

- fluxo da fase móvel: $1 \mathrm{~mL} / \mathrm{min}$;

- comprimento de onda: $320 \mathrm{~nm}$;

- coluna: Nova-Pak C18 (4 $\mu \mathrm{m})$, de 300 x 3,9 mm;

- temperatura considerada: $25^{\circ} \mathrm{C}$;

- volume injetado de amostra: $20 \mu \mathrm{L}$.

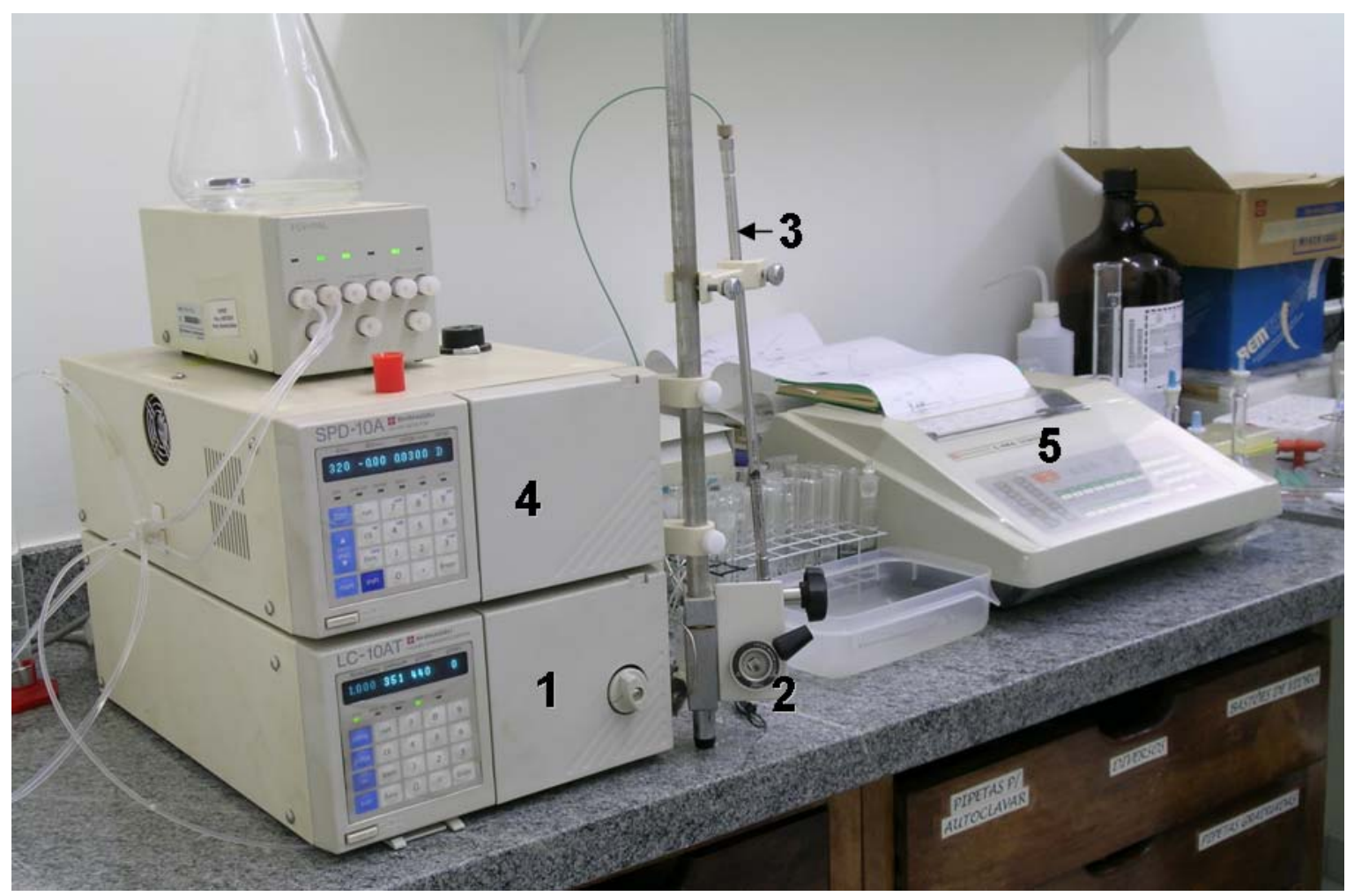

Figura 6. Cromatógrafo utilizado para dosagem de metronidazol nas amostras de fluido gengival. 1. sistema de bombeamento da fase móvel; 2. sistema de introdução da amostra injetor; 3. sistema analítico - coluna Cromatográfica; 4. sistema de detecção; 5 . sistema de registro e tratamento de dados - integrador 


\subsubsection{Análise dos resultados}

O resultado da análise cromatográfica é expresso graficamente no chamado cromatograma. Ele é formado por um conjunto de picos que representam as substâncias presentes em uma amostra. A Fig. 7 mostra o cromatograma de uma amostra com concentração conhecida de metronidazol $(4 \mu \mathrm{g} / \mathrm{mL})$. O pico único demonstra o tempo de retenção do metronidazol na coluna cromatográfica. Uma amostra que tenha um pico nesse tempo (3,433 minutos) identifica de forma positiva a presença do metronidazol.

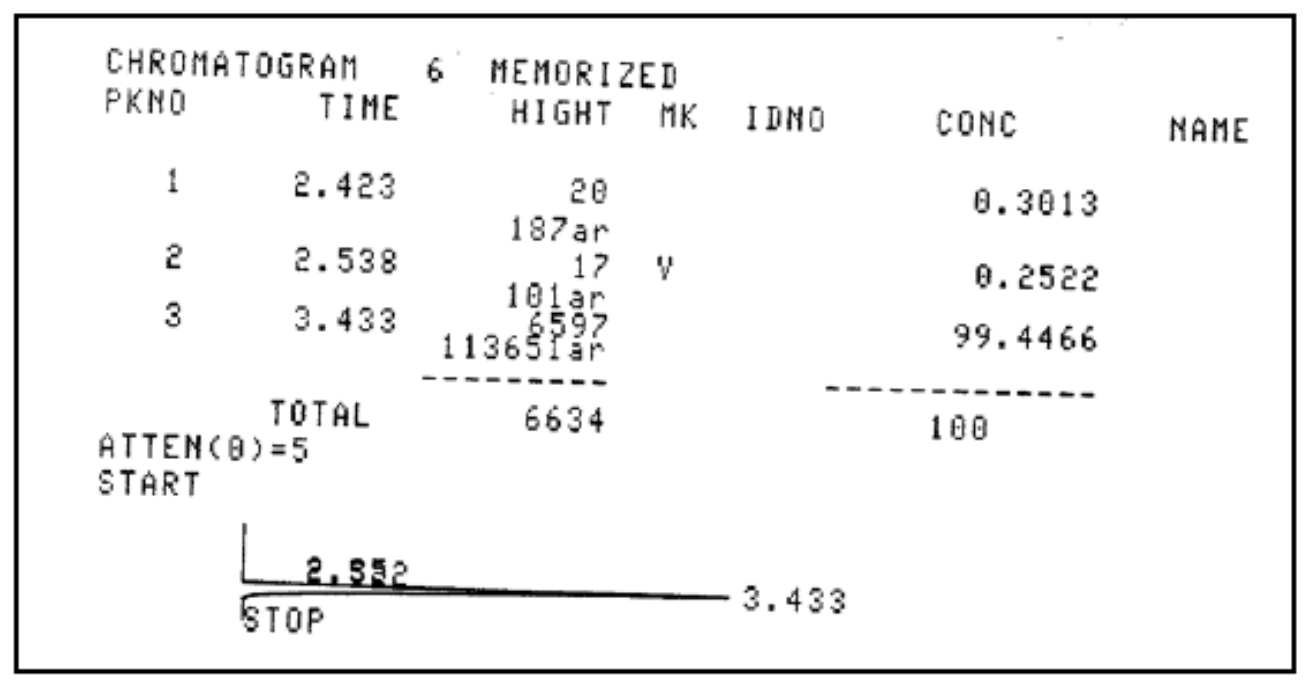

Figura 7. Cromatograma de uma solução padrão de metronidazol com uma concentração conhecida $(4 \mu \mathrm{g} / \mathrm{mL})$.

Para a determinação da concentração do metronidazol, foi construída uma curva-padrão, obtida por regressão linear, plotando-se em um gráfico as alturas de pico correspondentes a várias concentrações conhecidas de metronidazol. A partir da equação da reta obtida, substituem-se os valores da altura do pico obtida no cromatograma de cada amostra na equação da reta para se determinar a respectiva concentração do fármaco dosado. 
A avaliação do tempo de persistência do gel no interior das bolsas foi realizada pela dosagem do metronidazol no fluido gengival dos sítios que receberam o gel, sendo que enquanto fosse detectado o fármaco, considerava-se que o gel estava presente.

\subsection{Avaliação dos indicadores clínicos da periodontite}

De acordo com o protocolo estabelecido, descrito no item 4.2, um exame clínico-periodontal completo foi realizado previamente ao tratamento, com o objetivo de selecionar os sítios periodontais adequados para receberem os tratamentos e serem avaliados durante o estudo. Este exame foi realizado por um único examinador, por meio do sistema computadorizado de sondas periodontais, Florida Probe $^{\circledR}$ (Florida Probe ${ }^{\circledR}$ System, Florida Probe Corporation, Gainesville, FL, USA).

Este sistema é composto por uma sonda conectada a um reostato acionado com o pé, e a um software (FP32 versão 3.0.6.6 e o FP32 Data Downloader) instalado em um computador (Figura 8), capturando os registros das medidas de profundidade de sondagem e nível clínico de inserção com alta precisão e pressão controlada. Existem três tipos de peça de mão nas quais as pontas das sondas podem ser adaptadas, e neste estudo foi utilizada a ponta Stent, que possibilitou a tomada de ambos os parâmetros avaliados.(Figura 9 a, b).

Nesta primeira avaliação, realizada sete dias antes do tratamento ( $\mathrm{T}-7$, baseline), todos os dentes de cada indivíduo foram avaliados quanto aos seguintes parâmetros clínicos:

- Profundidade de sondagem (PS): distância, em milímetros, entre a margem gengival livre e a porção mais apical sondável da bolsa/sulco periodontal; 
- Nível clínico de inserção (NIC): distância, em milímetros, entre a junção cemento-esmalte e a porção mais apical sondável da bolsa/sulco periodontal;

Em cada dente as medições foram feitas em seis sítios (mésio-vestibular, vestibular, disto-vestibular, mésio-lingual, lingual e disto lingual). Para isso a ponta da sonda era inserida até a sua base (maior diâmetro) tocar na margem gengival (PS) ou na junção cemento-esmalte (NIC), quando o pedal era acionado, registrando as medidas (Figura 9) Após análise do periograma (Figura 10), foram selecionados dois dentes, em quadrantes distintos, com bolsas periodontais $\geq 5 \mathrm{~mm}$, sendo que, sempre eram selecionadas as bolsas de maior profundidade.

As mensurações dos parâmetros clínicos foram repetidas após sete (T 7), trinta ( $\mathrm{T}$ 30) e noventa ( $\mathrm{T}$ 90) dias do tratamento, apenas nos dois dentes selecionados no exame inicial ( $\mathrm{T}$-7, baseline), para comparação e avaliação dos tratamentos realizados. Porém, no T 90 o registro dos parâmetros clínicos com a sonda Florida Probe foi realizado em apenas 15 pacientes, pois um paciente não compareceu à consulta final e não pode ser avaliado a tempo. 

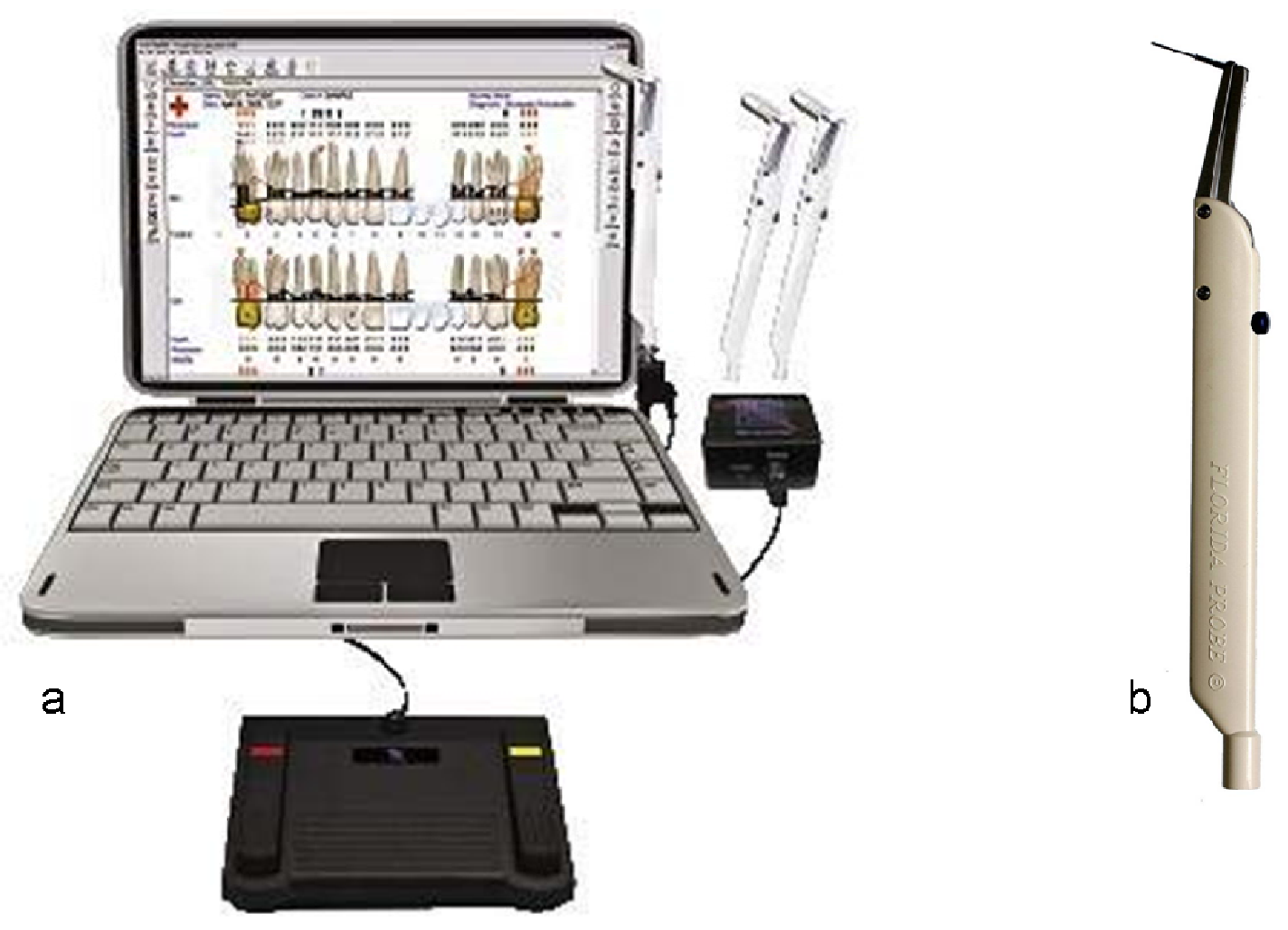

Figura 8. a) Sistema de sondagem periodontal Florida Probe ${ }^{\circledR}$, software, pedal e sonda; b) sonda periodontal.
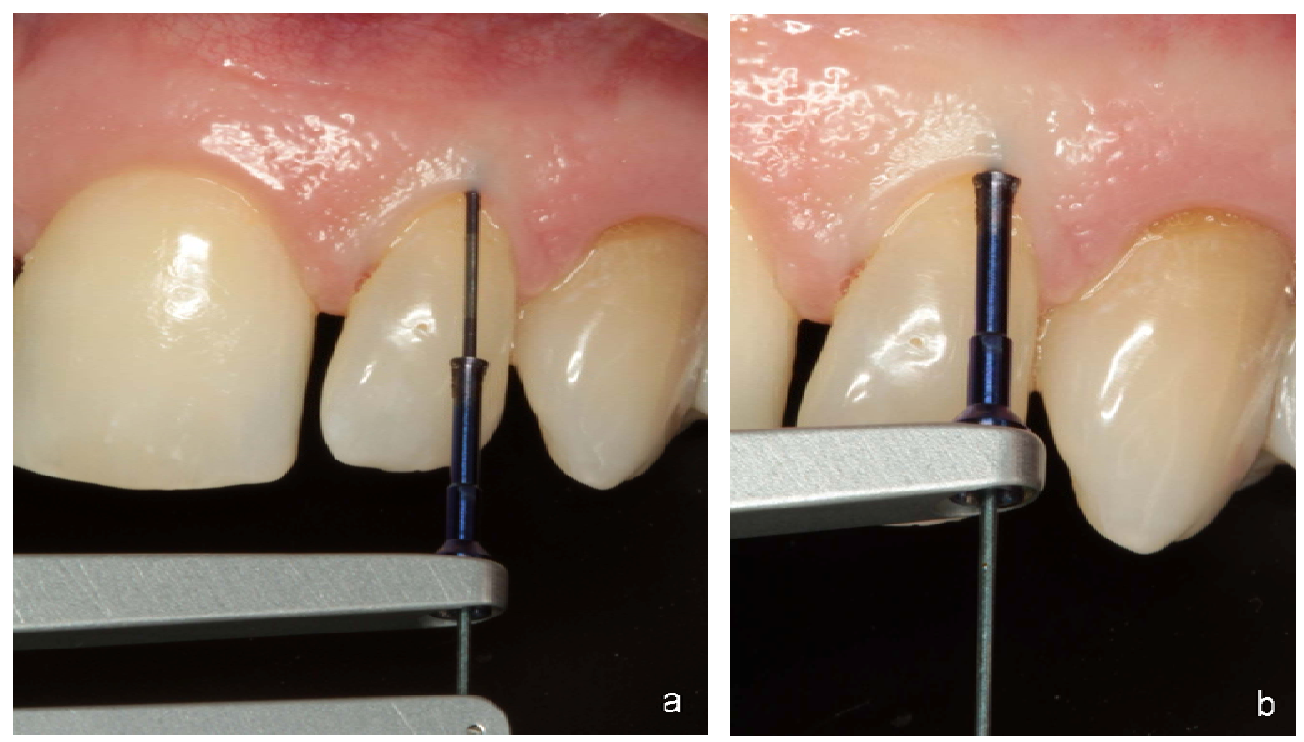

Figura 9. a) Inserção da sonda na bolsa periodontal; b) inserção da sonda periodontal (ponta stent) para registro da profundidade de sondagem 
Quadro Periodontal

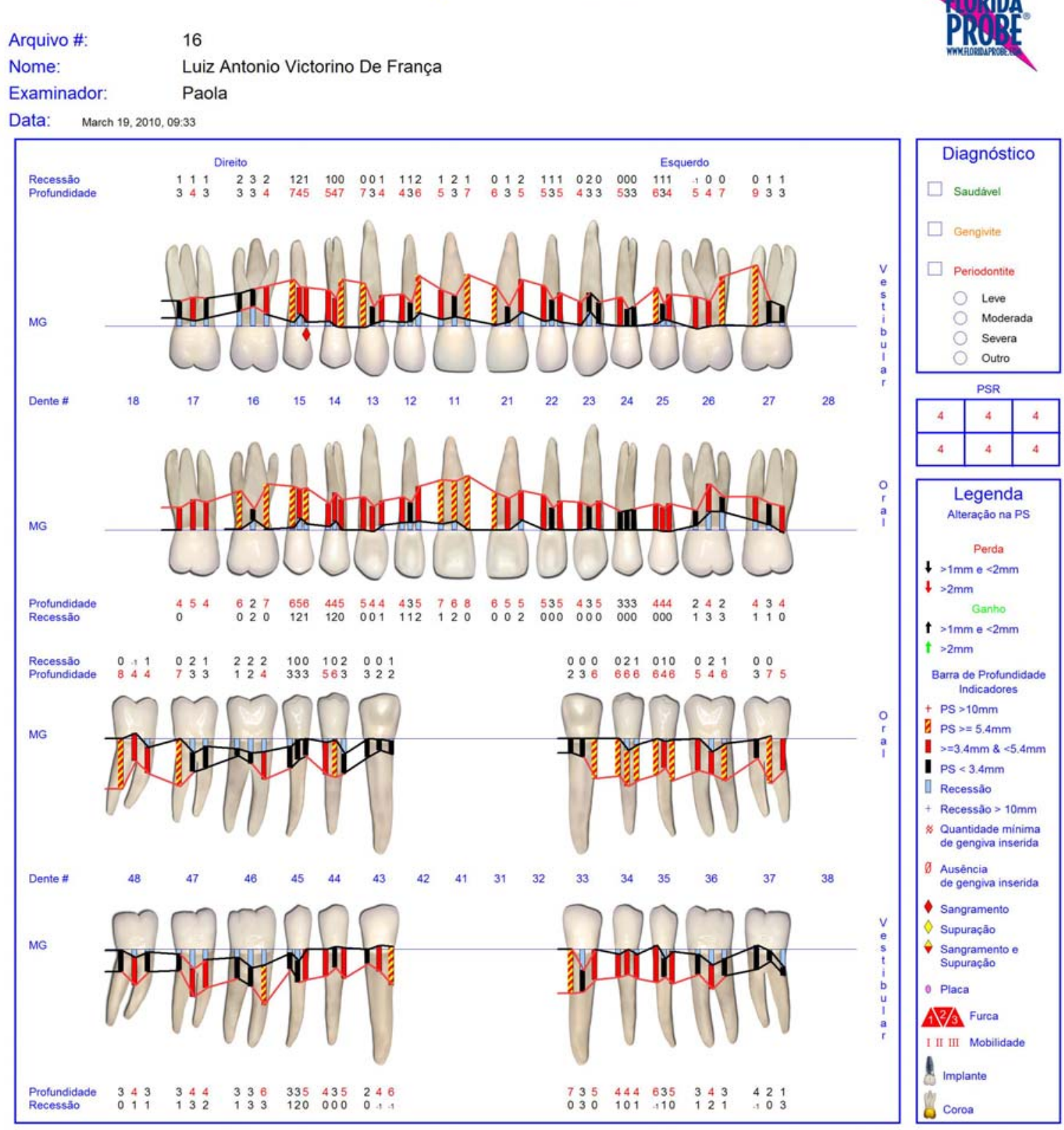

Figura 10. Registro dos parâmetros clínicos por meio do software e sonda computadorizada Florida Probe ${ }^{\circledR}$. 


\subsubsection{Análise dos resultados}

Os dados dos parâmetros clínicos (profundidade de sondagem e nível clínico de inserção) foram analisados com auxílio do software NCSS 2007 (NCSS, Kaysville, EUA).

Para isso, foi feita uma média aritmética das profundidades e dos níveis de inserção gengival das duas bolsas selecionadas, usando-se assim apenas essa média de cada paciente, em cada um dos tempos, para a comparação dos tratamentos RAR e RAR+GEL.

Por se tratar de variáveis contínuas, a profundidade de sondagem e o nível clínico de inserção foram submetidos à análise de variância de medidas repetidas, seguido pelo teste de Tukey-Kramer. Em ambas as análises, as diferenças significantes foram assinaladas quando $p<0,05$.

\subsection{Avaliação dos indicadores microbiológicos da periodontite}

\subsubsection{Colheita das amostras de biofilme subgengival}

Após a remoção do biofilme supragengival com gaze esterilizada, amostras de biofilme subgengival foram colhidas com o auxílio de curetas periodontais do tipo minifive (Hu-Friedy Mffg, Co., Chicago, IL, USA). Estas eram posicionadas na porção mais apical das bolsas e em um único golpe de raspagem no sentido ápico-coronal eram removidas e imediatamente depositadas em microtubos plásticos contendo $150 \mu \mathrm{L}$ de solução tampão TE (10 mM Tris-HCL (Sigma-Aldrich, Co., St. Louis, MO, EUA), 1 mM EDTA (Sigma HCL (Sigma-Aldrich, Co., St. Louis, MO, EUA), pH 7,6. A estas era acrescentado $150 \mu \mathrm{L}$ de $\mathrm{NaOH}$ (Labsynth) a 0,5M para que o DNA bacteriano permanecesse viável por um longo 
período de tempo. Os microtubos eram previamente marcados por números, os quais eram identificados em uma tabela com o nome do indivíduo, dente correspondente, grupo de tratamento, e data. Em seguida estes eram armazenados sob refrigeração a $-20^{\circ} \mathrm{C}$ até a realização das análises microbiológicas pelo método de hibridização DNA Chekerboard.

As amostras eram obtidas durante as consultas nas quais a avaliação clínica era realizada: antes do tratamento ( $\mathrm{T}-7$, baseline), sete ( $\mathrm{T} 7$ ) e trinta dias ( $\mathrm{T}$ 30) após o tratamento. No intuito de evitar contaminação das amostras com sangue, a colheita do biofilme subgengival era realizada previamente a sondagem.
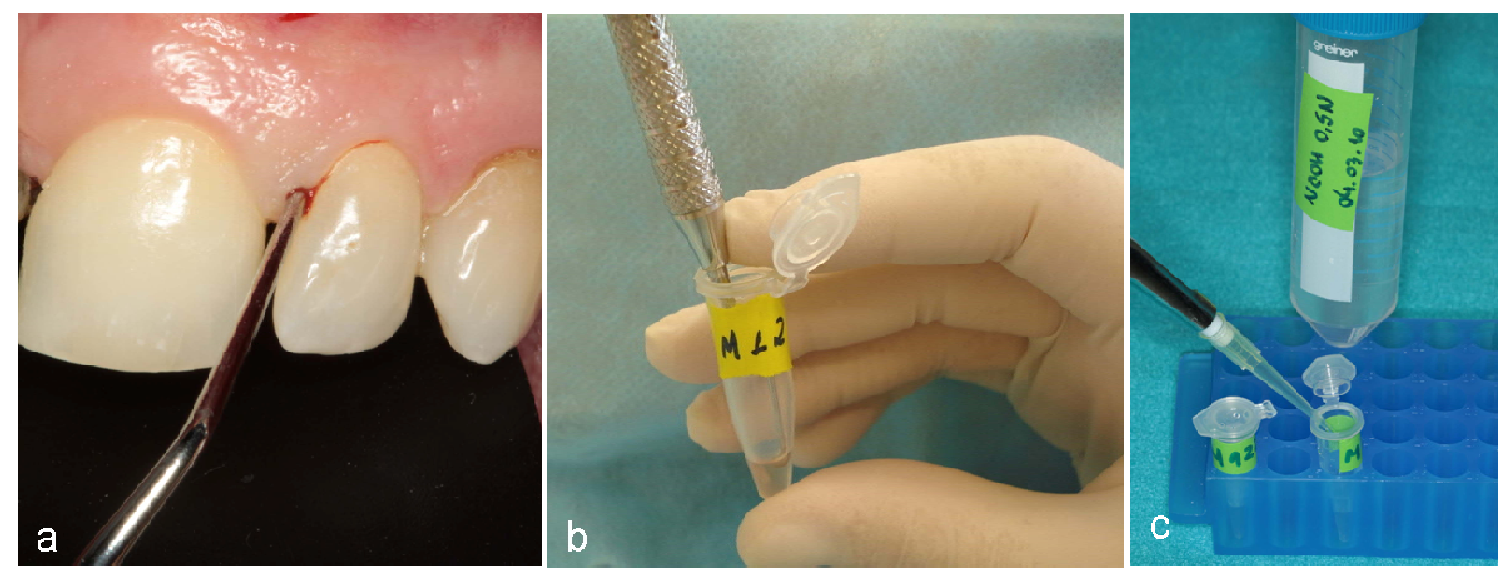

Figura 11. a) colheita do biofilme subgengival com cureta minifive; b) depósito da amostra de biofilme em solução tampão TE.; c) Aplicação de NAOH nos microtubos contendo as amostras.

\subsubsection{Análise da microbiota bucal pelo método DNA Checkerboard}

As amostras obtidas dos pacientes do Grupo 1 e Grupo 2 foram analisadas no Laboratório de Diagnóstico Odontológico Molecular da FORP-USP, por meio do método da hibridização com sondas de DNA genômico DNA Checkerboard, de acordo com (NASCIMENTO et al., 2010). 


\subsubsection{Obtenção das sondas de DNA genômico}

Os microrganismos utilizados neste estudo para confecção das sondas de DNA utilizadas na detecção das espécies, presentes nas amostras de biofilme subgengival dos pacientes avaliados, estão apresentadas na Tabela 2. A obtenção das cepas, assim como as etapas envolvidas no processo de crescimento e multiplicação das espécies bacterianas utilizadas neste estudo, foram realizadas pelo Dr. Cássio do Nascimento, junto ao Groupe de Recherche en Écologie Buccale (GREB) da Faculté de Médecine Dentaire da Université Laval (Canadá).

Da mesma forma, a extração, purificação do DNA genômico, amplificação do DNA extraído pela técnica do 16S rDNA-based PCR, e pela técnica do MDA (Multiple Displacement Amplification) e a avaliação da integridade dos DNAs genômicos obtidos para a confecção das sondas, foram realizadas de acordo com os protocolos descritos por Nascimento (2010).

De acordo com o autor, a técnica de amplificação MDA permite a obtenção de grandes quantidades de material genético para a construção de sondas e de amostras controle a partir de quantidades mínimas de DNA, e tem mostrado grande utilidade na amplificação do DNA proveniente de amostras clínicas, auxiliando na identificação de microrganismos que se encontram em quantidades extremamente reduzidas na microbiota oral. 
Tabela 2. Espécies bacterianas a serem avaliadas pelo método da hibridização DNA Checkerboard.

\begin{tabular}{|c|c|}
\hline ESPÉCIES BACTERIANAS & PROCEDÊNCIA \\
\hline Aggregatibacter Actinomycetemcomitans a & ATCC 29523 \\
\hline Aggregatibacter Actinomycetemcomitans $b$ & ATCC 29522 \\
\hline Bacteroides fragilis & ATCC 25285 \\
\hline Capnocytophaga gingivalis & ATCC 33624 \\
\hline Enterococcus faecalis & ATCC 51299 \\
\hline Eikenella corrodens & ATCC 23834 \\
\hline Porphyromonas gingivalis & ATCC 33277 \\
\hline Prevotella melaninogenica & ATCC 25845 \\
\hline Prevotella intermedia & ATCC 25611 \\
\hline Pseudomonas putida & ATCC 12633 \\
\hline Staphylococcus aureus & ATCC 25923 \\
\hline Streptococcus constelatus & ATCC 27823 \\
\hline Streptococcus mutans & ATCC 25175 \\
\hline Streptococcus oralis & ATCC 35037 \\
\hline Streptococcus sanguinis & ATCC 10556 \\
\hline Streptococcus sobrinus & ATCC 27352 \\
\hline Streptococcus salivarius & ATCC 25975 \\
\hline Streptococcus parasanguinis & ATCC 15911 \\
\hline Solobacterium moreei & CCUG 39336 \\
\hline Treponema denticola & ATCC 35405 \\
\hline Tanerella forsythensis & ATCC 43037 \\
\hline Veillonella parvula & ATCC 10790 \\
\hline Fusobacterium nucleatum & ATCC 25586 \\
\hline Fusobacterium periodonticum & ATCC 33693 \\
\hline Porphyromonas endodontalis & ATCC 35406 \\
\hline Peptostreptococcus micros & ATCC 33270 \\
\hline Neisseria mucosa & ATCC 25996 \\
\hline Pseudomonas aeruginosa & ATCC 27853 \\
\hline Streptocuccus gordonii & ATCC 10558 \\
\hline Streptococcus mitis & ATCC 49456 \\
\hline Lactobacilos casei & АTCC 393 \\
\hline Staphylococcus pasteuri & ATCC 51129 \\
\hline
\end{tabular}




\subsubsection{Processamento das amostras pela técnica de hibridização DNA Checkerboard}

\section{Confecção das Sondas Genômicas de DNA}

Os DNAs amplificados pela técnica do MDA foram marcados de acordo com o protocolo estabelecido pelo fabricante do marcador genômico (Amersham Gene Images AlkPhos Direct Labelling and Detection System, GE Healthcare, Buckinghamshire, UK). O protocolo baseia-se na marcação de 100 ng do DNA genômico do microrganismo a ser estudado, atingindo uma concentração final de 3 $\mathrm{ng} / \mu \mathrm{L}$ em solução de hibridização. Os DNAs foram diluídos dentro de microtubos à uma concentração de $10 \mathrm{ng} / \mu \mathrm{L}$ em um volume final $10 \mu \mathrm{L}$. Os DNAs foram desnaturados em água fervente por 5 minutos. Imediatamente, foram resfriados em gelo durante 5 minutos para manter as cadeias de nucleotídeos abertas. Com os tubos mantidos no gelo, foram adicionados os componentes do kit de marcação, primeiro $10 \mu \mathrm{L}$ de Reaction buffer, $2 \mu \mathrm{L}$ de Labelling reagent e $10 \mu \mathrm{L}$ de cross-link solution (1:4) [GE Healthcare] (Figura 12). Os tubos foram levemente agitados e incubados a $37^{\circ} \mathrm{C}$ por 30 minutos.

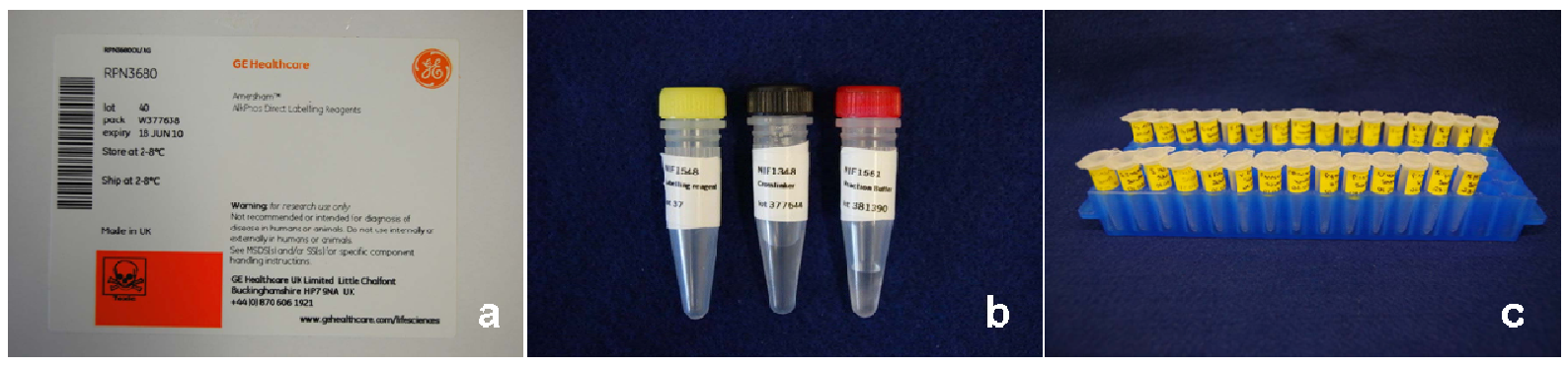

Figura 12. a) Kit usado para marcação das sondas de DNA genômico; b) Reagentes de marcação (labeling reagent, cross-linker solution e buffer reaction respectivamente); c) Sondas marcadas. 


\section{Verificação da sensibilidade e especificidade das sondas marcadas}

A sensibilidade do teste foi ajustada para permitir a observação de reações de hibridação positivas para a presença de $10^{5}$ e $10^{6}$ células bacterianas, de acordo com o proposto por Socransky et al. (1994). Para isso, amostras de DNA genômico usados para a confecção das sondas foram hibridizadas nas quantidades de $10^{5}$ e $10^{6}$ células contra as próprias sondas marcadas.

\section{Processamento e aplicação das amostras}

Previamente ao processamento, os microtubos contendo as amostras colhidas dos pacientes eram retirados do armazenamento a $-20{ }^{\circ} \mathrm{C}$ e mantidos a 4 ${ }^{\circ} \mathrm{C}$ para o descongelamento. Em seguida estes eram fervidos a $95{ }^{\circ} \mathrm{C}$ por 5 minutos para a desnaturação das fitas de DNA, e logo após, imersos em gelo. Após a desnaturação, as amostras eram neutralizadas com a adição de $800 \mu \mathrm{L}$ de acetato de amônio 5 M.

Um dispositivo metálico denominado Minislot 30 (Immunetics, Cambridge, MA, EUA), composto por duas placas metálicas, era utilizado para a fixação de uma membrana de nylon com carga positiva e tamanho de $15 \mathrm{~cm}^{2}$ (Hybond $\mathrm{N}+$, GE Healthcare), na qual as amostras eram aplicadas. Uma das placas do aparelho possui 30 canaletas dispostas paralelamente. Sobre esta, a membrana era posicionada de modo a cobrir todas as canaletas (Figura 13). O aparelho permite a deposição de 28 amostras de DNA em canaletas individuais. As duas canaletas restantes são utilizadas para a aplicação dos controles correspondentes a $10^{5}$ e $10^{6}$ células de cada espécie estudada.

Cada amostra de DNA e os controles eram aplicados no interior das canaletas com auxílio de pipetas automáticas de precisão, e após 5 minutos, o 
dispositivo era conectado a uma bomba à vácuo, removendo o excesso de líquido e, desta forma, permitindo a deposição do DNA na membrana. Logo após, eram feitas duas aplicações consecutivas de água destilada por meio das pipetas, para lavagem das canaletas, e o excesso de água era removido com o auxílio da bomba a vácuo. Em seguida, a membrana era removida do aparelho e o DNA fixado na mesma por meio da exposição ao calor de $80{ }^{\circ} \mathrm{C}$ no forno de hibridização (Hybridization Oven Shaker, Amersham Biosciences) por 2 horas.
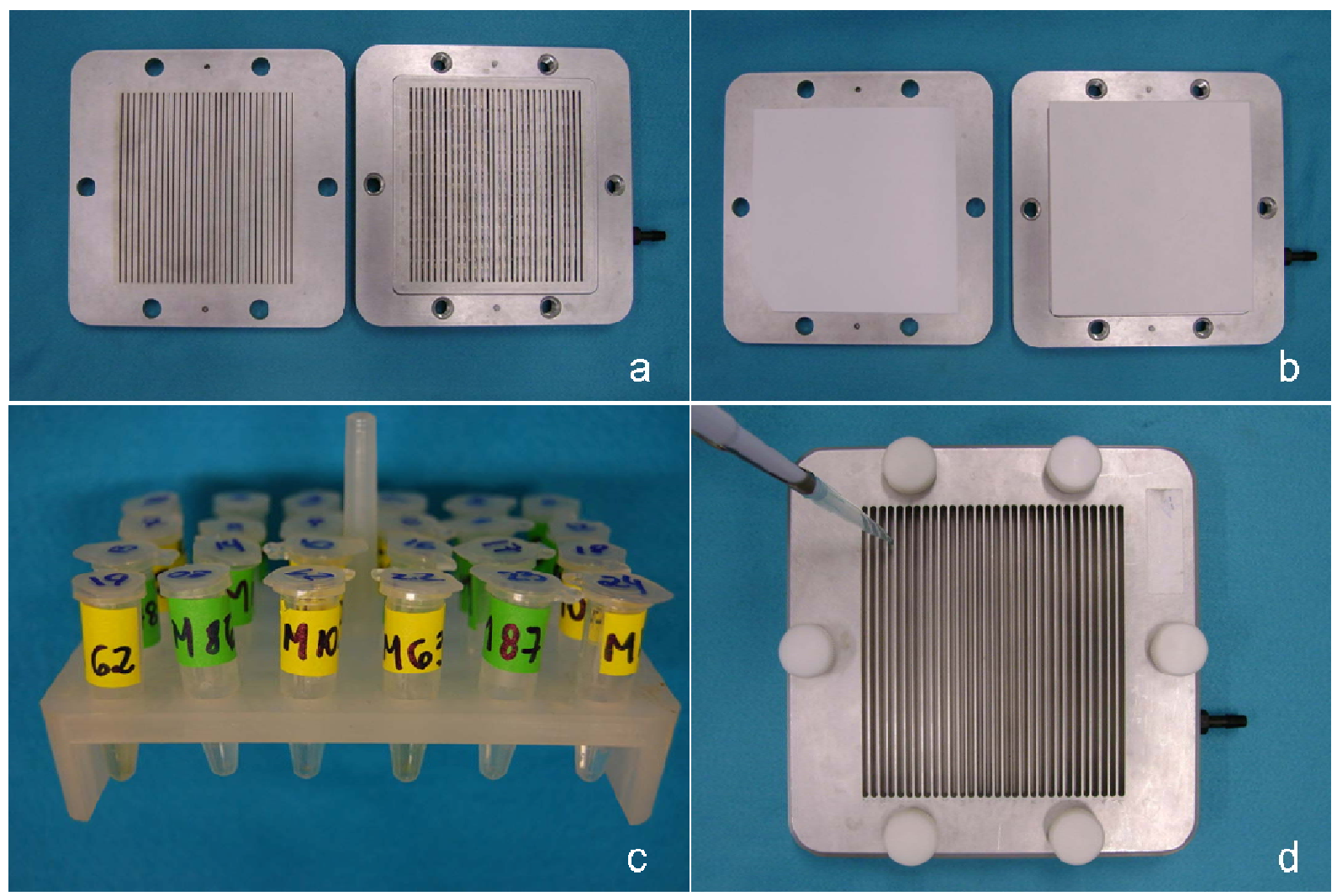

Figura 13. a) Aparelho Minslot 30 aberto; b) membrana de nylon posicionada sobre uma das placas do aparelho (esquerda) e papel filtro (direita); c) amostras de fluido gengival prontas para serem aplicadas na membrana d: Membrana posicionada no aparelho fechado e aplicação das amostras em canaletas individuais.

\section{Pré-Hibridização das amostras}

Após a fixação dos DNAs das amostras e controles, a membrana era préhibridizada no forno a $60{ }^{\circ} \mathrm{C}$, durante 2 horas, em uma solução de $\mathrm{NaCl} 1 \mathrm{M}$ (Merck) 
e Blocking reagent (4\%, GE Healthcare) diluídos em $30 \mathrm{~mL}$ de Hybridization Buffer (GE Healthcare). A Figura 14 ilustra o forno de hibridização utilizado no processamento das membranas.

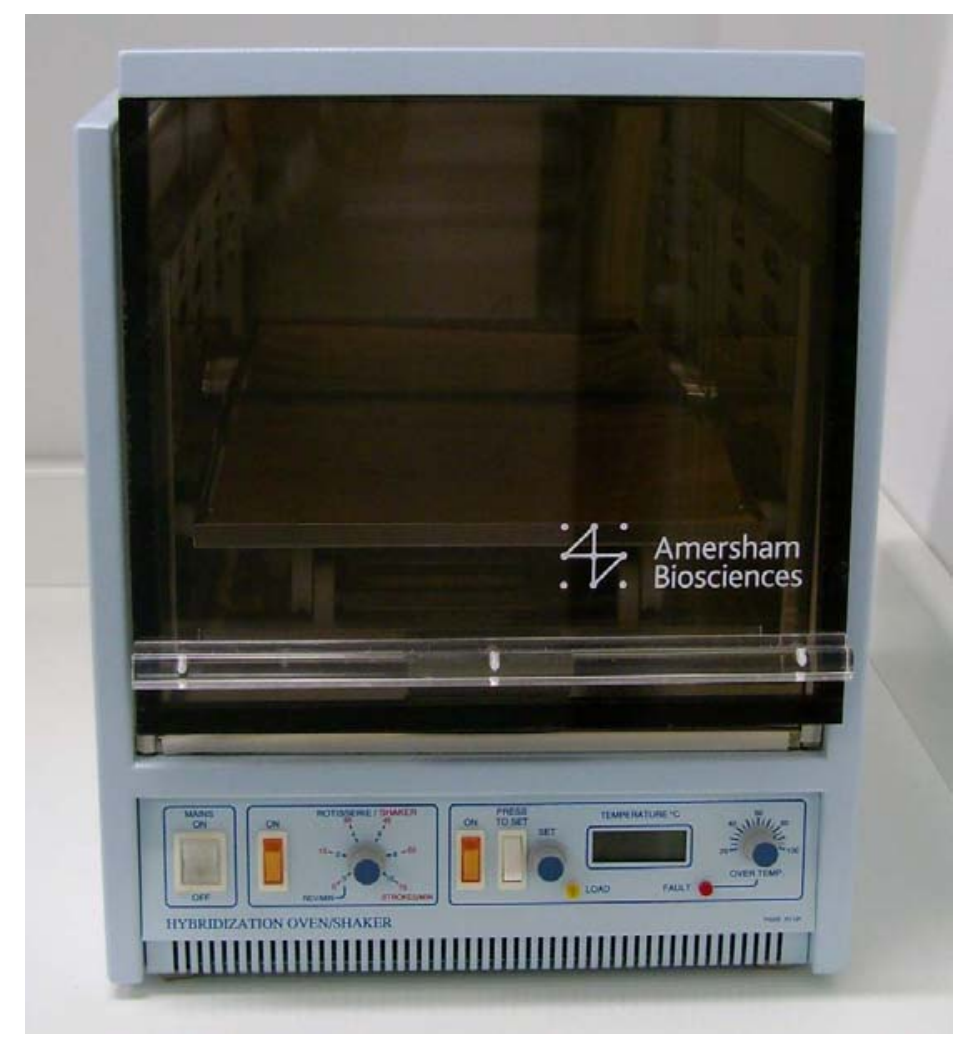

Figura 14. Forno de hibridização utilizado para a fixação das amostras de DNA sobre a membrana, pré e hibridização das membranas, e para os procedimentos de lavagem.

\section{Aplicação das sondas de DNA marcadas e reação de hibridação}

Após a pré-hibridização, a membrana era posicionada em um aparelho de acrílico (Miniblotter 45, Immunetics, Cambridge, MA, EUA), com 45 canais, nos quais as sondas marcadas eram aplicadas. (Figura 15). A membrana é posicionada de forma que as amostras de DNA previamente aplicadas fiquem posicionadas em um ângulo de $90^{\circ}$ com os canais do aparelho de acrílico, formando um checkerboard no padrão 30 (amostras) X 45 (sondas). Cada canal é usado como uma câmara para 
reações de hibridização independentes. Com o auxílio de pipetas automáticas de precisão, eram aplicadas, individualmente no interior de cada canal, quantidades de sonda pré-estabelecidas no teste de verificação da sensibilidade e especificidade das sondas marcadas. Após a aplicação das sondas, o aparelho era embrulhado várias vezes em filme de PVC (cloreto de polivinil) e embalado em saco plástico, evitando desta forma a possibilidade de desidratação da membrana. A hibridização da membrana era realizada a $60{ }^{\circ} \mathrm{C}$ no forno, sob agitação suave, durante 16 horas.

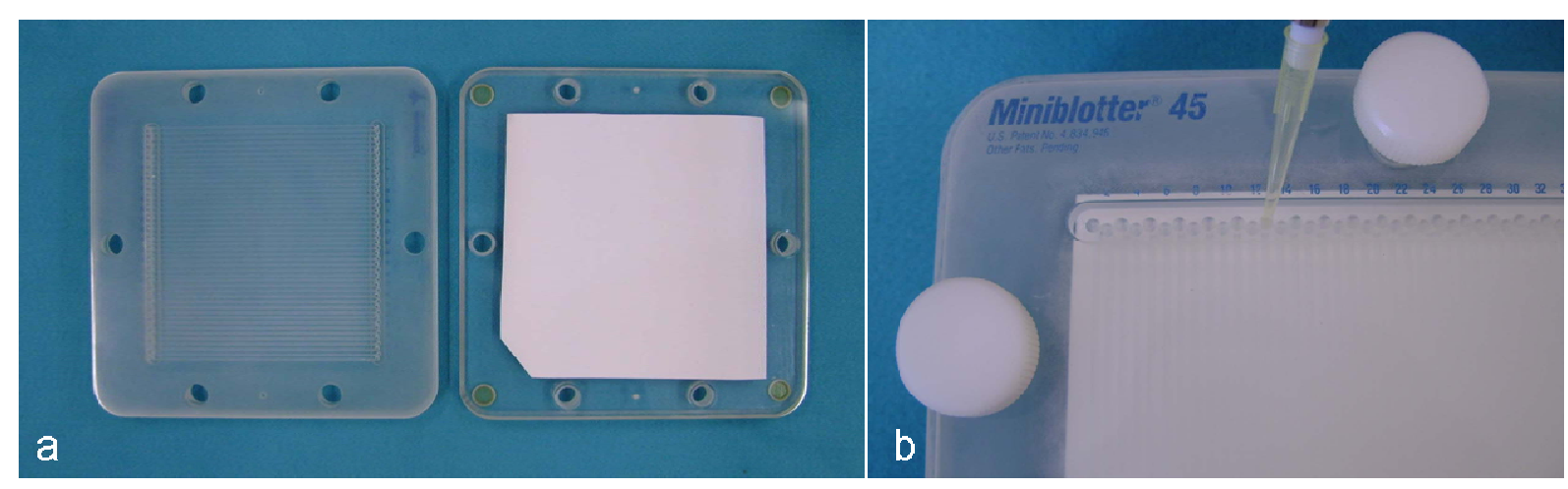

Figura 15. Aparelho Miniblotter 45 para aplicação das sondas. a: Membrana posicionada sobre uma das placas do aparelho; b: Após o fechamento do aparelho, as sondas são aplicadas individualmente nas canaletas.

\section{Lavagem para remoção das sondas}

Após a reação de hibridização, a membrana passa por um processo de lavagem, a fim de remover as sondas que não hibridizaram completamente (ligações inespecíficas entre os DNAs). Inicialmente eram realizadas duas lavagens de 35 minutos cada, a $65^{\circ} \mathrm{C}$, com $500 \mathrm{~mL}$ de uma solução contendo Urea 2 M (Sigma), Sodium Dodecyl Sulfate (SDS) 0,1\% (Sigma), NaH2SO4 50 mM (pH= 7; Merck), $\mathrm{NaCl} 150$ mM (Merck), MgCl2 1mM (Merck) e Blocking Reagent (GE Healthcare). Duas lavagens subseqüentes eram realizadas em temperatura ambiente, durante 15 minutos cada, com $500 \mathrm{~mL}$ de uma solução contendo Tris $1 \mathrm{M}$ (Sigma), $\mathrm{NaCl} 2 \mathrm{M}$ 
(Merck) e $\mathrm{MgCl} 21 \mathrm{M}$ (Merck). Todas as lavagens eram conduzidas sob vigorosa agitação no forno de hibridização/lavagem.

\section{Detecção dos sinais de hibridização}

A detecção dos sinais de hibridização é feita através de uma reação de quimiluminescência. Após as lavagens, eram aplicados sobre a membrana, 6,7 mL do reagente de detecção CDP-Star ${ }^{\circledR}$ (GE Healthcare), deixando-o agir em toda a superfície por 5 minutos. Após este período, o excesso do reagente era removido e a membrana selada em saco plástico para o procedimento de exposição.

\section{Exposição da membrana e Revelação}

A membrana selada era posicionada para exposição em filme para autoradiografia (HyperFilm, GE Healthcare) dentro de um cassete apropriado (Hypercassette, GE Healthcare). Eram realizadas 3 exposições diferentes para cada membrana processada (15, 30 e 60 minutos). Em seguida, os filmes eram revelados e fixados em soluções para processamento radiográfico convencional (Kodak, Brasil). Ao final, obtém-se um filme radiográfico com os sinais de hibridização detectados pelas intersecções entre as amostras e sondas, onde as linhas horizontais representam as sondas marcadas e as verticais, as amostras de biofilme subgengival, configurando desta forma um "tabuleiro de xadrez" - DNA Checkerboard (Figura 16). 

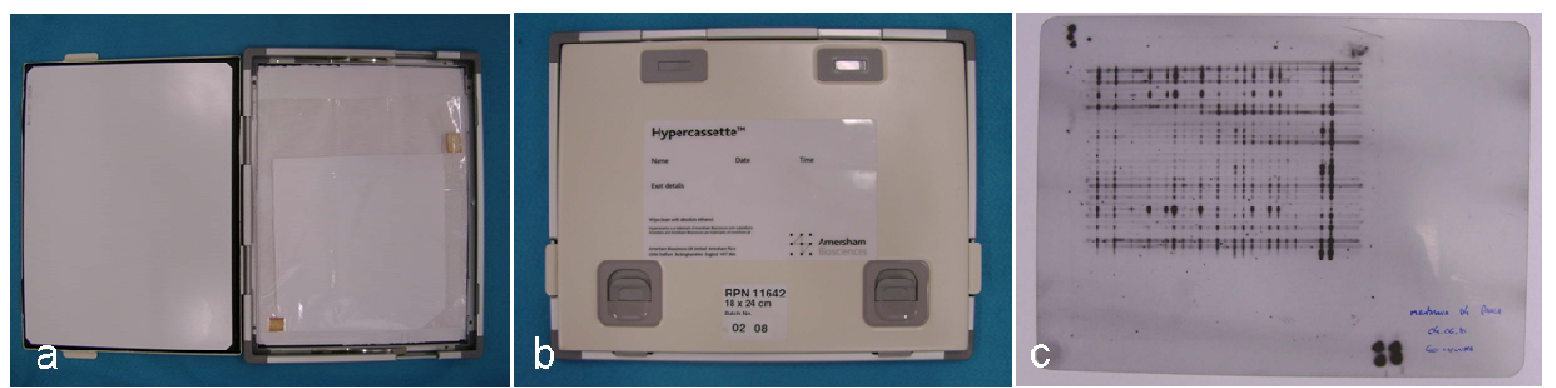

Figura 16. a) e b) Membrana embalada e posicionada no cassete radiográfico; c) Filme radiográfico revelado, onde se pode observar os sinais das reações de hibridização obtidas pelo método DNA Checkerboard.

\section{Interpretação dos Sinais de Hibridização}

A leitura visual dos resultados é semi-quantitativa, feita por meio da comparação da intensidade dos sinais de hibridização obtidos pela intersecção das amostras testadas contra as sondas marcadas em relação à intensidade das amostras controle colocadas nas duas últimas canaletas do Minislot 30, que equivalem a $10^{5}$ e $10^{6}$ células das espécies alvo. Os sinais são registrados como 0 : não detectado; 1: $<10^{5}$ células; 2: $\sim 10^{5} ; 3: 10^{5} \sim 10^{6} ; 4: \sim 10^{6}$; e $5:>10^{6}$ células, de acordo com Socransky et al. (2004). Desta forma, obtém-se um número aproximado de células bacterianas em cada amostra estudada. Sendo assim, os filmes radiográficos foram digitalizados e as imagens obtidas foram inseridas no software Image Quant TL (GE Healthcare). O software possibilita a obtenção do número aproximado de células bacterianas presentes em cada amostra avaliada através da comparação da intensidade de pixels dos sinais de hibridização entre as amostras e controles. A Figura 17 ilustra algumas etapas da quantificação dos sinais das amostras obtidas nas membranas, por meio do software. 


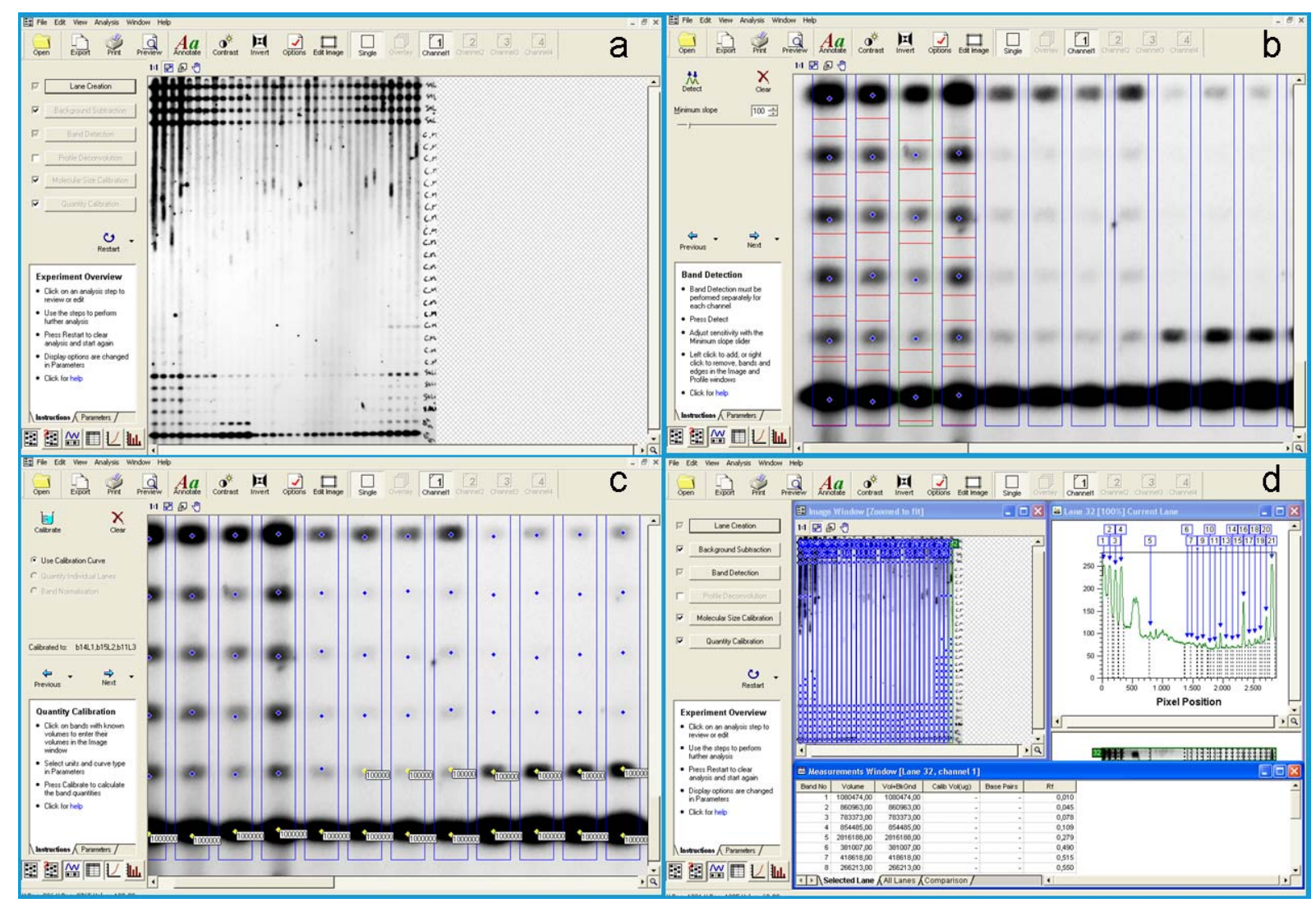

Figura 17. a) Imagem digitalizada de uma membrana, inserida no software; b) seleção dos sinais de hibridização a serem quantificados; c) determinação dos valores dos sinais controles; d) calibração de todos os sinais em função dos controles e obtenção dos resultados.

\subsubsection{Análise dos dados}

O número de células bacterianas (Contagem) e incidência das espécies foram fornecidas para cada grupo estudado nos três tempos avaliados. Para comparar as contagens das espécies bacterianas em cada grupo, inicialmente os dados foram avaliados somando-se todos os microrganismos, sem discriminar entre as espécies estudadas. Os dados obtidos foram analisados pelo teste de TukeyKramer. Diferenças foram consideradas significantes para valores de $p<0,05$. Em seguida as espécies foram analisadas individualmente para cada grupo nos tempos propostos neste estudo. As contagens bacterianas foram analisadas pelo método de Kruskal-Wallis seguido do teste post-hoc de Dunn para comparações entre os diferentes grupos. Os dados foram analisados utilizando o software estatístico Graphpad Instat (GraphPad Software, Inc., La Jolla, CA, USA). 
5 Resultados 


\section{RESULTADOS}

\subsection{Resultado do monitoramento da concentração de metronidazol no fluido} gengival

$\mathrm{Na}$ Tabela 3 encontram-se as médias das concentrações de metronidazol presentes no fluido gengival dos oito pacientes pertencentes ao Grupo 2 (RAR + gel), em função do tempo de colheita das amostras. Essas médias foram calculadas para os dois sítios avaliados em cada paciente.

Tabela 3. Estatística descritiva da concentração de metronidazol (em $\mu \mathrm{g} / \mathrm{mL}$ de Fluido gengival) dos sítios que receberam o metronidazol, determinada pela CLAE.

\begin{tabular}{lrrrr}
\hline & \multicolumn{4}{c}{ Tempo } \\
\cline { 2 - 5 } Estatística & imediato & 1h & $\mathbf{4 8 h}$ & $\mathbf{7 d}$ \\
\hline \hline & & & & \\
$\mathbf{N}$ & 16 & 16 & 16 & 14 \\
N-Met (\%) * & $16(100)$ & $15(93,75)$ & $1(6,25)$ & $0(0)$ \\
Média & 47034,91 & 398,83 & 0,35 & 0 \\
Desvio Padrão & 19757,48 & 598,90 & 1,42 & 0 \\
Mediana & 51888,14 & 131,2 & 0 & 0 \\
Mínimo & 13783,33 & 0 & 0 & 0 \\
Máximo & 81638,66 & 1965,12 & 5,66 & 0 \\
Intervalo & 67855,33 & 1965,12 & 5,66 & 0 \\
* Freqüência total de sítios com metronidazol detectado, com a porcentagem em parênteses.
\end{tabular}

Pode-se observar pela Tabela 3 que altas concentrações do fármaco no fluido gengival foram obtidas apenas imediatamente após a aplicação do gel (47034,91 $\mu \mathrm{g} / \mathrm{mL})$, ocorrendo uma grande diminuição nas concentrações a partir das colheitas realizadas após 1 hora $(398,93 \mu \mathrm{g} / \mathrm{mL})$. Após 48h horas da aplicação do gel, apenas um sítio apresentou resultado positivo $(6,25 \%)$ para a presença de 
metronidazol, com valor extremamente reduzido $(0,35 \mu \mathrm{g} / \mathrm{mL})$, e após sete dias o fármaco não foi detectado em nenhuma amostra. Na Fig.18 observa-se uma representação gráfica dos valores médios da concentração de metronidazol $(\mu \mathrm{g} / \mathrm{mL})$, apresentados na Tabela 3, em função do tempo de colheita das amostras de fluido gengival.

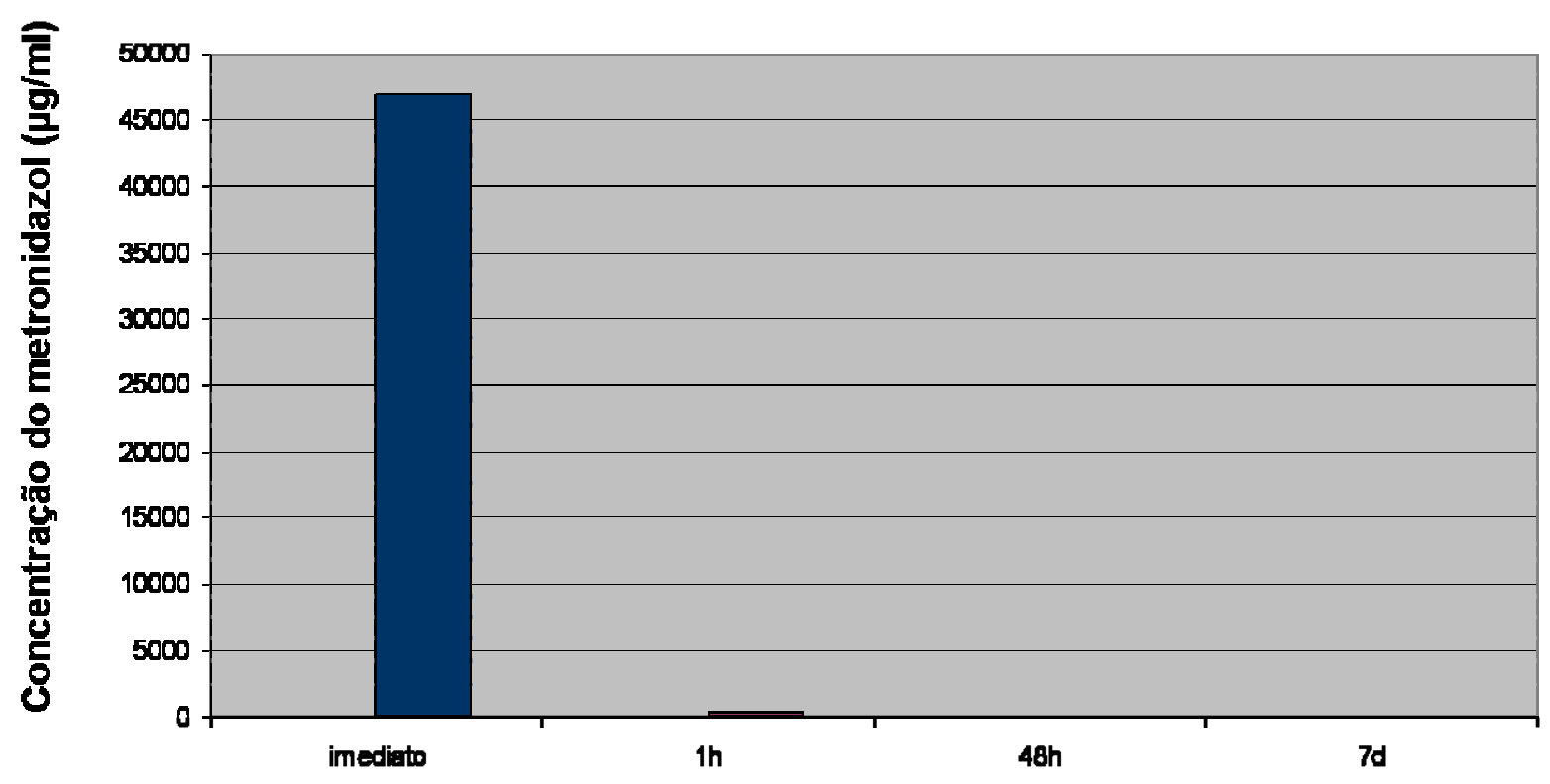

Tempo de colheita das amostras

Figura 18. Gráfico representativo das concentrações de metronidazol detectadas no fluido gengival em função do tempo de colheita das amostras.

\subsection{Resultados da análise dos parâmetros clínicos}

Dos 16 pacientes que permaneceram no estudo, um faltou à consulta final e não pôde ser avaliado a tempo, sendo excluído da análise dos dados. Este paciente pertencia ao grupo tratado com o gel, e portanto os registros no $\mathrm{T} 90$ (noventa dias após as terapias) para este grupo correspondem a 7 pacientes. 


\subsubsection{Profundidade de sondagem}

O resultado da análise de variância de medidas repetidas, revelou que houve diferença significante entre os grupos $(F=8,60, p=0,011)$, e entre os tempos de avaliação ( $F=18,75, p=0,000025$ - nível de significância com ajuste de Geisser-Greenhouse). O resultado da interação Grupo x Tempo não foi significante $(F=0,38, p=0,766)$.

$\mathrm{Na}$ Tabela 4 estão dispostos os dados das médias da profundidade de sondagem de cada grupo (RAR e RAR + Gel), nos quatro tempos de avaliação: início do estudo ( $\mathrm{T}-7$, baseline); e sete dias ( $\mathrm{T}$ 7), um mês ( $\mathrm{T}$ 30) e três meses ( $\mathrm{T}$ 90) após as terapias.

Tabela 4. Resultado da análise da interação Grupo (tratamento) x Tempo e as médias de profundidade de sondagem dos grupos em função do tempo, obtidas pelo teste de TukeyKramer.

\begin{tabular}{|c|c|c|c|c|}
\hline $\begin{array}{c}\text { Grupo } \\
\text { Tratamento }\end{array}$ & Tempo & $\mathbf{N}$ & Médias(mm) & $\begin{array}{l}\text { Diferença entre os pares } \\
\qquad(p<0,05)\end{array}$ \\
\hline \multirow{4}{*}{$\begin{array}{c}\text { Grupo1 } \\
\text { (RAR) }\end{array}$} & $\mathrm{T}-7$ & 8 & 5,612 & (RAR T 7), (RAR T 30), (RAR T 90) \\
\hline & T 7 & 8 & 4,075 & (RAR T -7), (Gel T 7) \\
\hline & T 30 & 8 & 3,600 & (RAR T -7) \\
\hline & T 90 & 8 & 3,650 & (RAR T -7) \\
\hline \multirow{4}{*}{$\begin{array}{c}\text { Grupo2 } \\
\text { (RAR + Gel) }\end{array}$} & $\mathrm{T}-7$ & 8 & 6,825 & (Gel T 30), (Gel T 90) \\
\hline & $\mathrm{T} 7$ & 8 & 5,720 & (RAR T 7) \\
\hline & T 30 & 8 & 5,012 & (Gel T -7) \\
\hline & T 90 & 7 & 4,585 & $(\mathrm{Gel}-7)$ \\
\hline
\end{tabular}

* As diferenças obtidas entre os pares com tempos distintos, omitidas nesta tabela, estão dispostas no Apêndice A.-1

Pelo observado na tabela 4, o Grupo 2 (RAR + Gel) apresentou uma profundidade de sondagem média sempre mais alta do que o grupo 1, entretanto, foi detectada diferença estatística entre os grupos 1 e 2, levando-se em consideração o 
tempo, apenas no T $7(\mathrm{p}<0,05)$. No baseline $(T-7)$ as médias das profundidades de sondagem do grupo que foi tratado com a RAR e do Grupo que recebeu a RAR + o gel de metronidazol foram, respectivamente de 5,612 mm e 6,825 mm. Após três meses da instituição das terapias (T90) a medida da PS no Grupo 1 foi de 3,650 mm e no Grupo 2, foi de 4,865 mm (tabela1). Considerando-se a diferença entre a PS medida aos 90 dias após o tratamento e a medida realizada no baseline, o Grupo 2 apresentou uma redução de 2,24 mm, enquanto que o Grupo 1 apresentou uma redução de 1,96 $\mathrm{mm}$. Em ambos os grupos houve uma redução progressiva nas profundidades de sondagem em função do tempo de avaliação clínica (Figura 19).

No grupo que recebeu apenas a RAR, pode ser observada redução significante da PS em todos os tempos (T 7, T30 e T90) em comparação ao ao baseline (T-7), enquanto que no grupo que recebeu a RAR + o gel de metronidazol, a redução foi significante, comparada ao baseline, apenas nos tempos T 30 e T90 $(p<0,05)$. Após 7 dias a PS foi reduzida, porém não foi significante $(p>0,05)$ (Tabela 4).

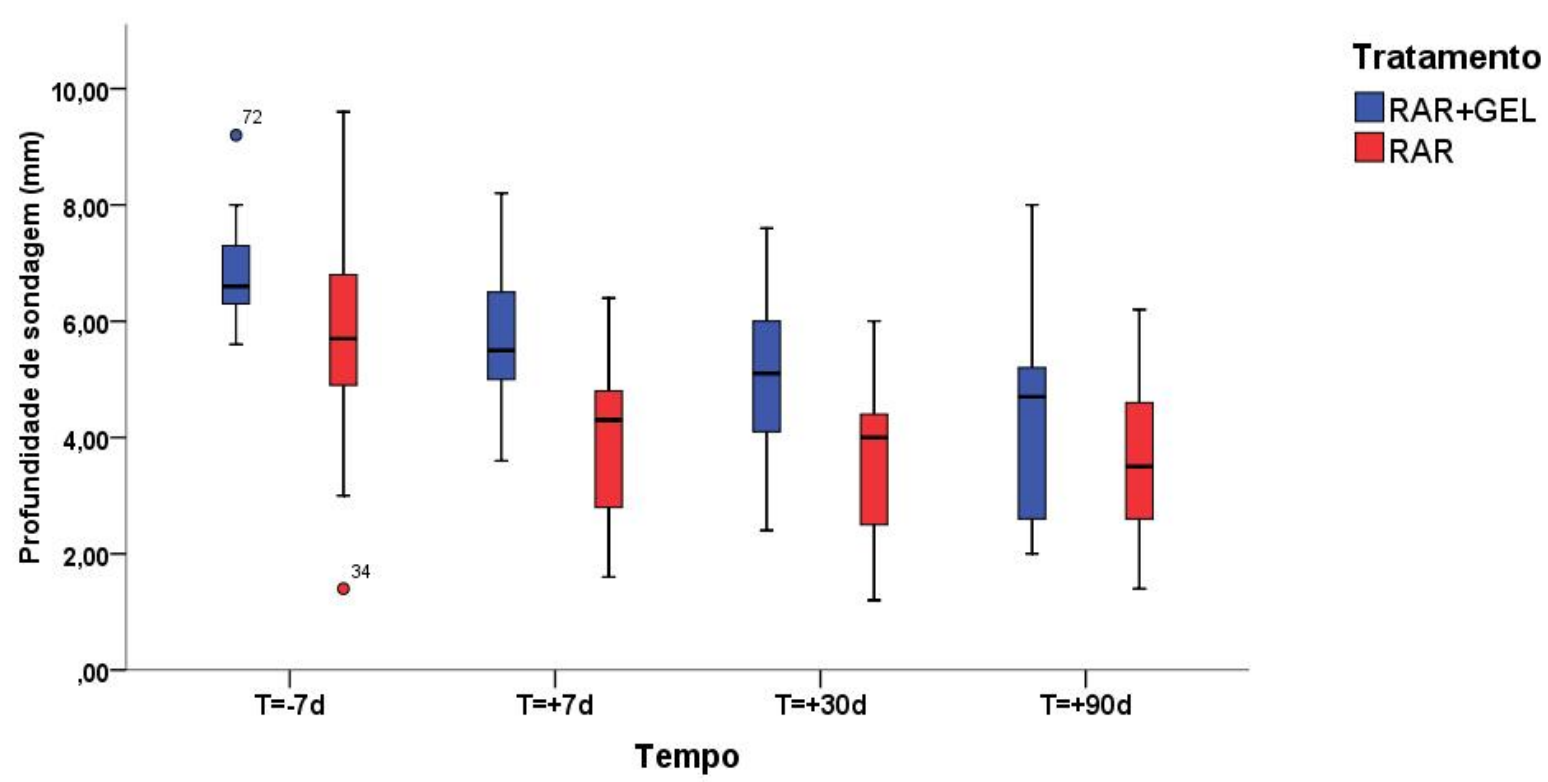

Figura 19. Representação esquemática (boxplot) da redução da profundidade de sondagem nos grupos tratados com a RAR e com a a RAR + gel de metronidazol em função do tempo em que a avaliação clínica foi realizada. 


\subsubsection{Nível clínico de inserção}

A análise de variância de medidas repetidas, realizada para comparar os grupos e os tempos não detectou diferença entre os tratamentos da RAR e da RAR $+o$ gel de metronidazol $(F=3,77, p=0,07)$. Entretanto, foi observada diferença significante em relação aos tempos de avaliação ( $F=15,50, p=0,000030$ - nível de significância com ajuste de Geisser-Greenhouse). O resultado da interação Grupo x tempo não foi significante $(F=0,82, p=0,490)$.

$\mathrm{Na}$ tabela 5 estão dispostas as médias dos níveis de inserção clínico observados nos Grupos 1 e 2 em relação ao tempo de avaliação clínica.

Tabela 5. Resultados da análise da interação Grupo (tratamento) x Tempo, e médias dos níveis de inserção clínico dos grupos em função do tempo, obtidos pelo teste de TukeyKramer.

\begin{tabular}{ccccc}
\hline $\begin{array}{c}\text { Grupo } \\
\text { Tratamento }\end{array}$ & Tempo & N & $\begin{array}{c}\text { Médias (mm) } \\
\text { e desvios- } \\
\text { padrão }\end{array}$ & $\begin{array}{c}\text { Diferença entre os pares } \\
(\mathbf{p}<0,05)\end{array}$ \\
\hline \hline & T-7 & 8 & 6,137 & (RAR T30), (RAR T90) \\
$\begin{array}{c}\text { Grupo1 } \\
\text { (RAR) }\end{array}$ & T 7 & 8 & 5,375 & (Gel T 7) \\
& T 30 & 8 & 5,025 & (RAR T-7) \\
\hline T 90 & 8 & 4,975 & (RAR T-7) \\
Grupo2 & T-7 7 & 8 & 7,500 & (Gel T 30), (Gel T 90) \\
(RAR + Gel) & T 30 & 8 & 6,837 & (Gel T 90) \\
& T 90 & 7 & 5,6137 & $($ Gel T -7) (Gel T 7) \\
\hline \hline
\end{tabular}

*As diferenças obtidas entre os pares com tempos distintos, omitidos nesta tabela, estão despostos no Apêndice A-2.

De acordo com a Tabela 5 , os valores médios dos níveis de inserção clínica do Grupo 2 (RAR + GEL), assim como na profundidade de sondagem, 
também foram mais altos do que os valores obtidos no Grupo 1 (RAR), em todos os tempos, sendo detectada diferença estatística entre os grupos em relação ao tempo, após 7 dias dos tratamentos. Embora tenha sido observado um "ganho" progressivo no nível clínico de inserção em função do tempo (Figura 20) em ambos os grupos, houve diferença significante, em relação ao baseline, apenas nos tempos T 30 e T 90, tanto para o Grupo 1 quanto para o Grupo $2(p<0,05)$. Após uma semana dos tratamentos ( $\mathrm{T}$ 7), o ganho de inserção não foi significante em nenhum dos grupos $(p>0,05)$.

Ao final do estudo, três meses após a instituição das terapias, o ganho de inserção clínica, obtido quando as medidas dos níveis de inserção do tempo T 90 foram subtraídas das medidas iniciais (T-7), foi de 1,162 no Grupo 1(RAR) e 1,886 no grupo 2 (RAR + Gel), (T -7).

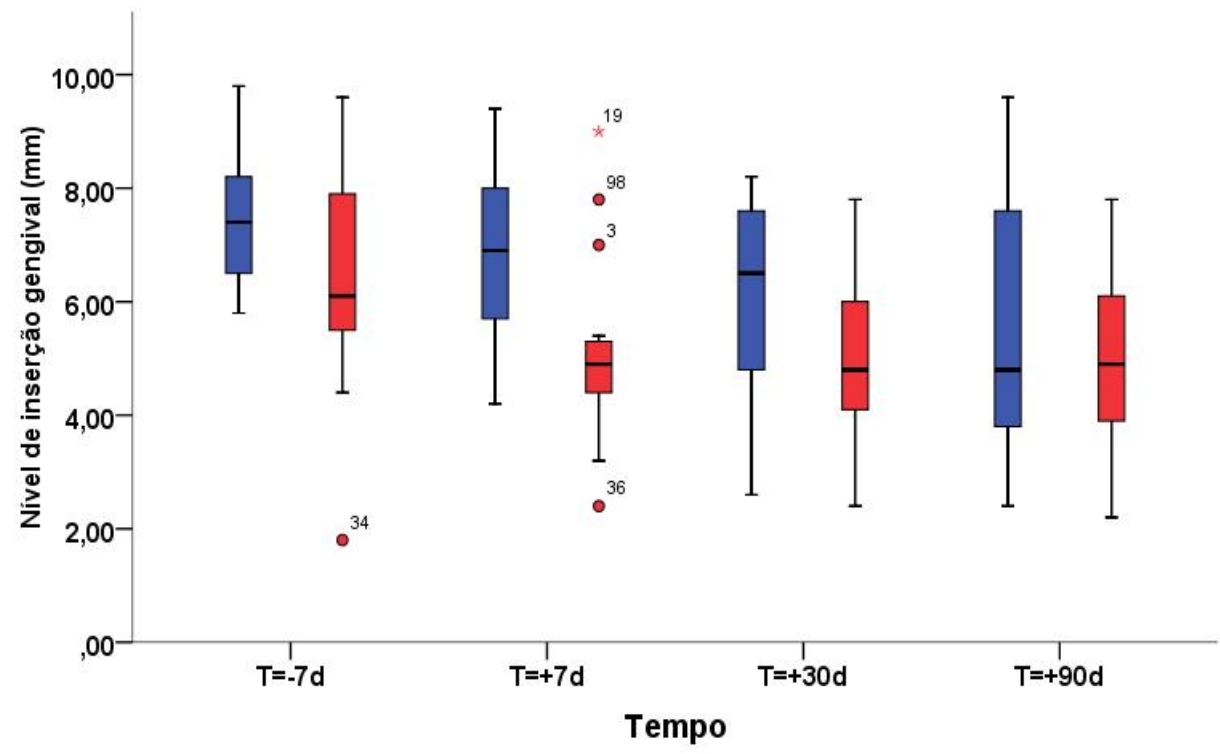

Tratamento $\square$ RAR+GEL $\square R A R$

Figura 20. Representação esquemática (boxplot) dos níveis de inserção clínica dos Grupos RAR e RAR + Gel em função do tempo de avaliação clínica. 


\subsection{Resultados da análise microbiológica pelo método DNA Checkerboard.}

A Figura 21 ilustra a imagem radiográfica digitalizada de uma das membranas obtida após a reação de hibridização das sondas de DNA genômico das espécies avaliadas com as amostras do biofilme subgengival colhido dos pacientes tratados (Grupo 1 e Grupo2), antes ( $\mathrm{T}$-7) e depois dos tratamentos ( 7 e T30).

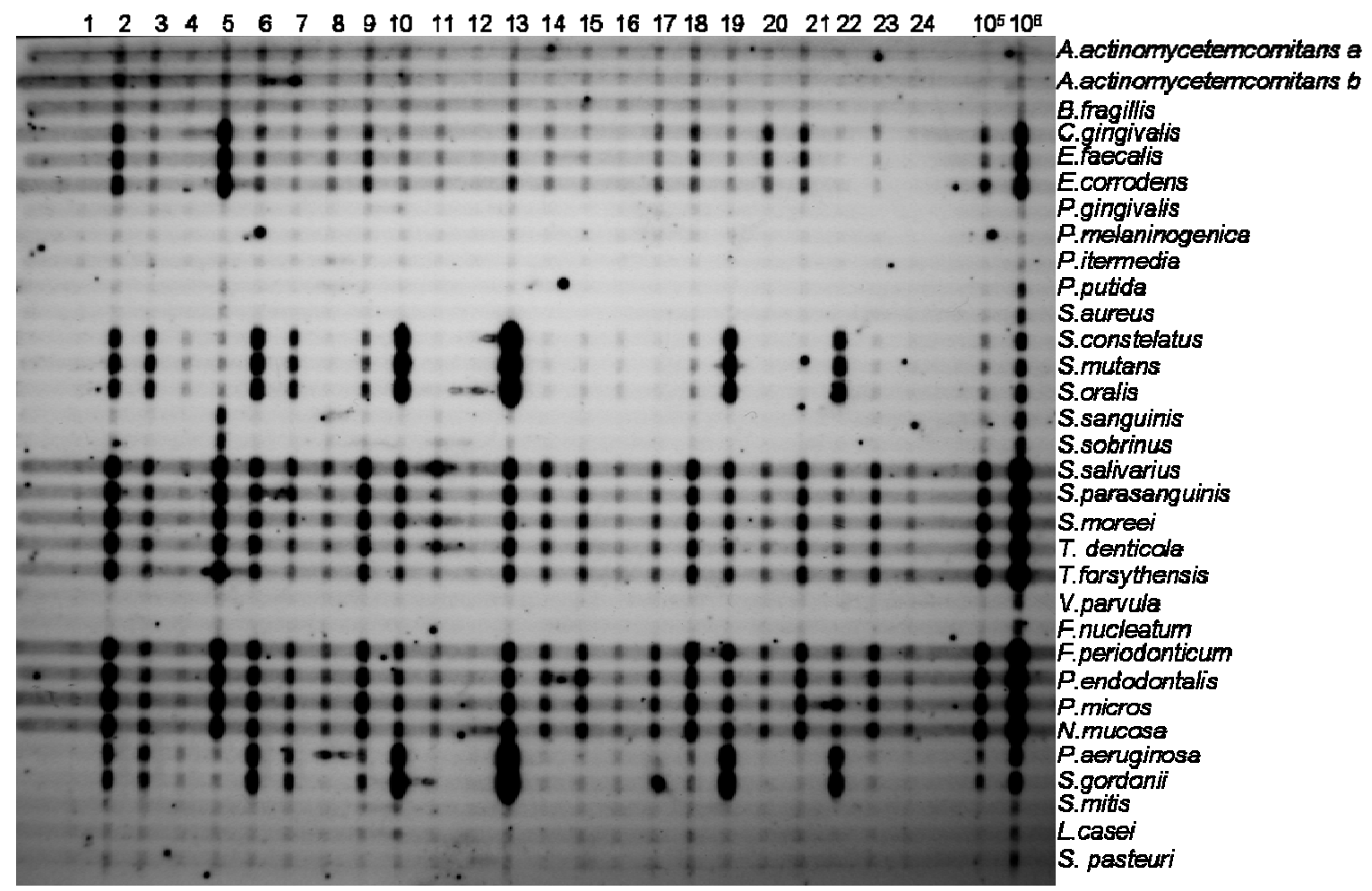

Figura 21. Imagem da membrana digitalizada, obtida após a reação de hibridização. As linhas verticais representam as amostras $(1-24)$ e controles $\left(10^{5}\right.$ e $\left.10^{6}\right)$, e as linhas horizontais as sondas das 32 espécies bacterianas avaliadas.

As médias da contagem bacteriana $\left(\times 10^{5}, \pm \mathrm{DP}\right)$ das 32 espécies avaliadas nas amostras provenientes dos pacientes tratados com RAR (Grupo1) ou com RAR + o gel de metronidazol (Grupo 2), nos três períodos de avaliação propostos ( $\mathrm{T}-7$, baseline, sete dias antes do tratamento; $\mathrm{T} 7$, sete dias depois do tratamento; T 30, trinta dias depois do tratamento) estão dispostos na Figuras 22. 
Baseline RAR

Aa

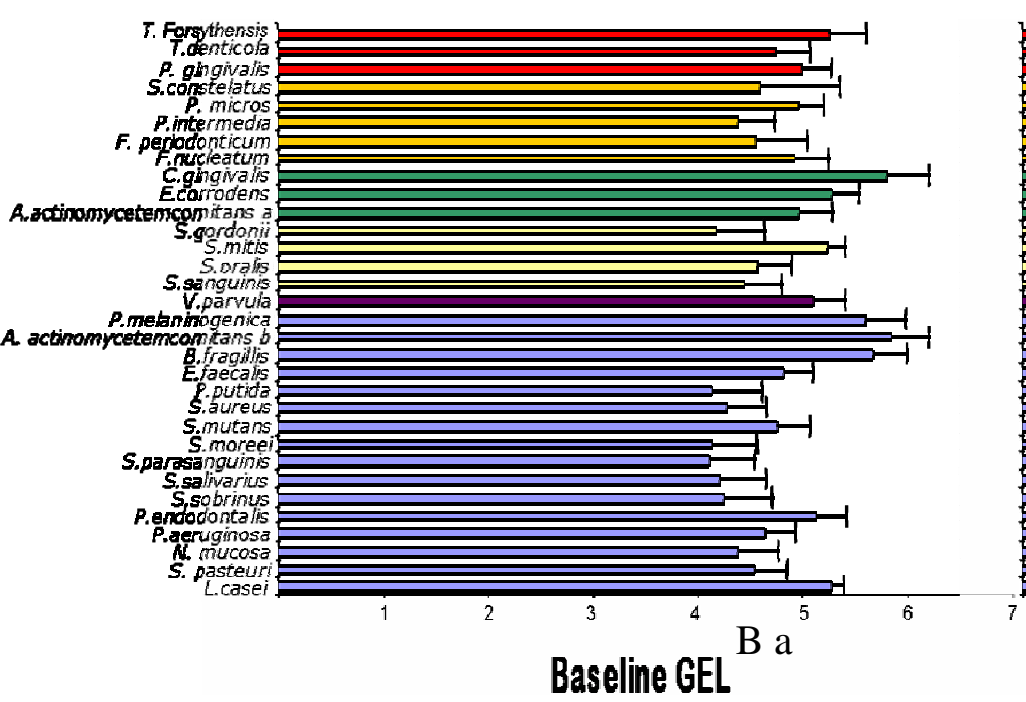

Baseline GEL

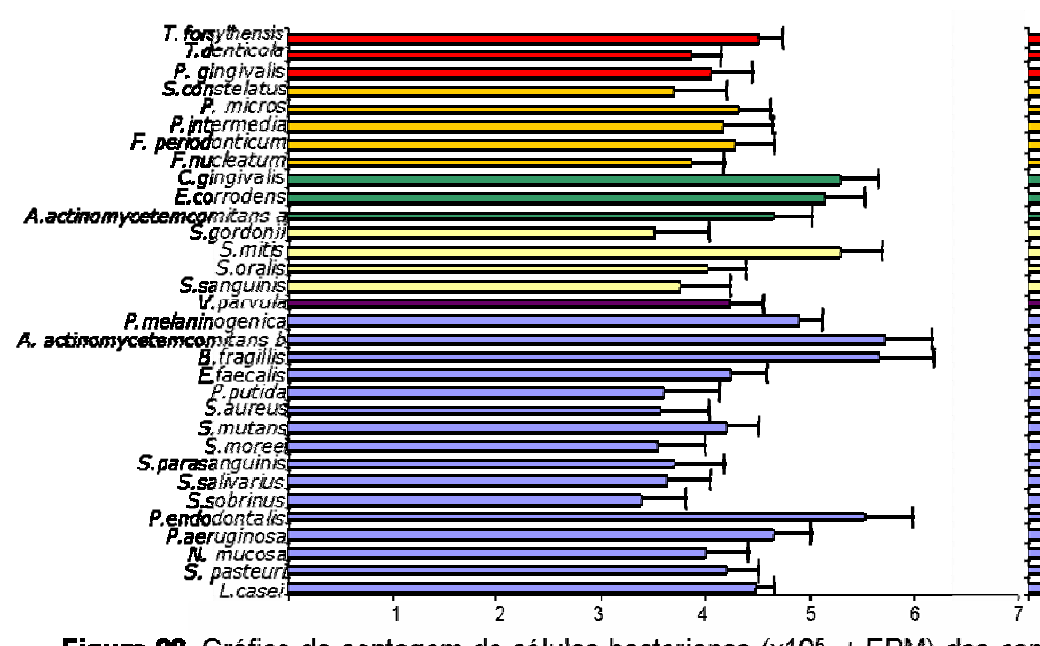

Figura 22. Gráfico da contagem de células bacterianas $(\times 105, \pm \mathrm{EPM})$ das espécies presentes nas amostras de biofilme subgengival dos grupos avaliados. Diferentes letras maiúsculas representam as diferenças significantes entre os grupos. (RAR e RAR + Gel). Diferentes letras minúsculas representam diferenças significantes dentro de um mesmo grupo em função do tempo de colheita das amostras. As diferenças foram detectadas, considerando a somatória total das espécies, pelo teste estatistico de Tukey-Kramer, $(p<0,05)$. Neste gráfico as espécies foram agrupadas de acordo com os complexos microbianos descritos por Socransky e Haffajee, 2004.
T7-RAR
T30 - RAR
Aa
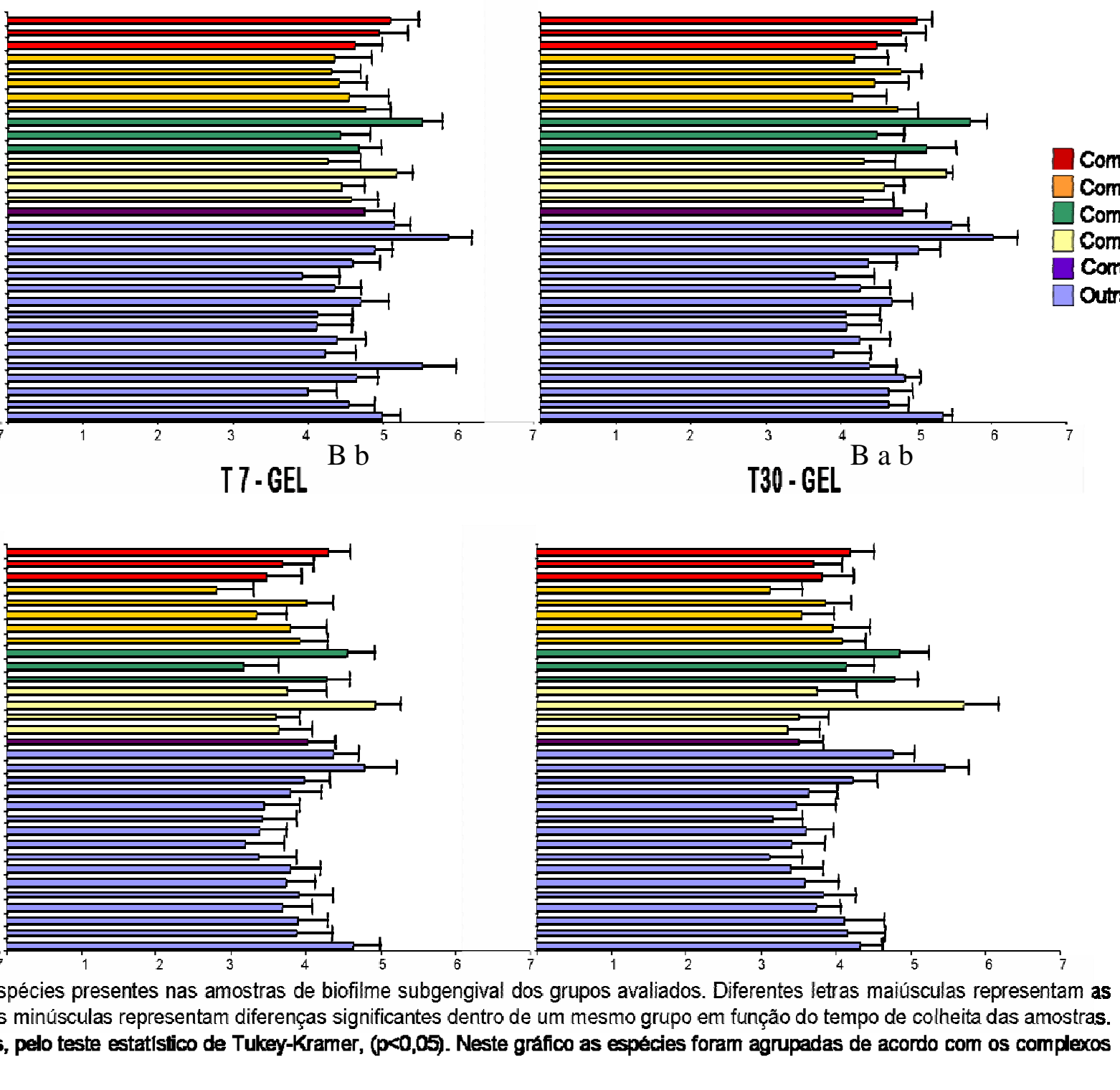

Complexo vermetho

Complexo Laranja

Complexo verde

Complexo amarelo

Complexo roxo

Outras 
As maiores contagens bacterianas $\left(\times 10^{5}, \pm \mathrm{EMP}\right)$ para as amostras provenientes dos pacientes do grupo controle (Grupo 1- RAR), no baseline ( $T$-7, sete dias antes do tratamento) foram observadas para as espécies Aggregatibacter actnomycetemcomitans b $(5,84 \pm 0,36)$ e Capnocyitophaga gingivalis $(5,80 \pm 0,39)$. No período T 7 (sete dias depois do tratamento), as maiores contagens foram observadas para a Aggregatibacter actnomycetemcomitans b $(5,86 \pm 0,32), P$. endodontalis $(5,51 \pm 0,45)$ e Capnocyitophaga gingivalis $(5,51 \pm 0,27)$. e Bacteroides fragilis $(5,66 \pm 0,52)$. As espécies Aggregatibacter actnomycetemcomitans b $(6,02 \pm$ $0,32)$ e Capnocyitophaga gingivalis $(5,71 \pm 0,23)$ obtiveram as maiores contagens no T 30 (30 dias após o tratamento).

Para os pacientes do grupo teste (Grupo 2 - RAR + gel de metronidazol) o maiores valores obtidos no baseline ( $\mathrm{T}-7$, sete dias antes do tratamento) foram para as espécies Aggregatibacter actnomycetemcomitans b $(5,71 \pm 0,46)$ e Bacteroides fragilis (5,66 \pm 0,52). As espécies Estreptococos mitis $(4,92 \pm 0,35)$ e Aggregatibacter actnomycetemcomitans b $(4,78 \pm 0,43)$ demonstraram os maiores valores de contagem bacteriana no período T 7 (sete dias após o tratamento), e Estreptococos mitis $(5,70 \pm 0,46)$ e Aggregatibacter actnomycetemcomitans b $(5,44 \pm$ 0,33) no período T 30 (30 dias após o tratamento).

Comparando-se os tratamentos (RAR e RAR+ gel) nos períodos de avaliação propostos, quando as amostras foram avaliadas sem distinção entre as espécies investigadas, foi encontrada diferença significante na contagem bacteriana entre os grupos, nos três tempos de avaliação T -7 $(p<0,01)$, T $7(p<0,001)$ e no T 30 $(p<0,001)$, sendo que os pacientes que receberam o gel de metronidazol (Grupo2) apresentaram menores valores de contagem de bactérias (Figura 22 e Tabela 6). 
Quando os resultados foram avaliados em relação ao tempo de colheita das amostras foi observado que os valores da contagem bacteriana para o grupo que recebeu apenas a raspagem e alisamento radicular (Grupo1-RAR) não demonstraram diferença significante $(p>0,05)$ após sete $(T$ ) e trinta dias $(T 30)$ do tratamento quando comparados ao baseline (T-7).

Para o grupo que recebeu a raspagem e alisamento radicular mais a aplicação do gel de metronidazol, houve diferença significante apenas no $T$, quando os resultados foram comparados em relação ao baseline $(p<0,05)$. Entretanto, no período de avaliação T 30, embora a contagem bacteriana tenha se mantido reduzida em relação ao baseline ( $T$-7), não foi encontrada diferença estatística $p>0,05)$. A tabela 6 corresponde às médias obtidas para cada grupo nos três tempos de avaliação microbiológica.

Tabela 6. Médias das contagens bacterianas $\left(X 10^{5}\right)$ obtidas pelo teste de Tukey-Kramer para os Grupos 1 e 2, nos tempos em que as colheitas de biofilme gengival foram realizadas.

\begin{tabular}{|c|c|c|c|c|c|}
\hline Grupo & Tempo & Média & Desvio padrão & Erro Padrão & Mediana \\
\hline \multirow{3}{*}{ RAR } & $\mathbf{T - 7} \dagger$ & 4,798 & 0,509 & 0,09 & 4,745 \\
\hline & $\mathbf{T} 7$ & 4,645 & 0,453 & 0,08 & 4,570 \\
\hline & $\mathbf{T} 30^{\dagger \dagger}$ & 4,655 & 0,523 & 0,092 & 4,595 \\
\hline \multirow{3}{*}{ RAR + GEL } & T-7 † & 4,294 & 0,668 & 0,118 & 4,190 \\
\hline & $\mathbf{T} 7$ * † & 3,823 & 0,482 & 0,085 & 3,785 \\
\hline & $\mathbf{T} 30^{\dagger \dagger}$ & 3,925 & 0,628 & 0,011 & 3,770 \\
\hline
\end{tabular}

No que diz respeito à incidência das espécies, os resultados da contagem bacteriana demonstraram que em todas as amostras, de ambos os grupos e nos três tempos de colheita do biofilme gengival, a frequência foi de $100 \%$ para a maioria das espécies avaliadas, exceto as espécies Bacteroides fragilis, Pseudomonas putida, 
Strepctococcus oralis e Streptococcus constelatus, que apresentaram uma incidência discretamente menor (Tabela 7).

Tabela 7. Incidência das espécies (em porcentagem) nas amostras de biofilme gengival dos pacientes submetidos ao tratamento com RAR e RAR + gel de metronidazol.

\begin{tabular}{|c|c|c|c|c|c|c|}
\hline $\begin{array}{l}\text { Espécies } \\
\text { Bacterianas } \\
\end{array}$ & $\mathrm{T}$-7 RAR & $\mathrm{T}-7 \mathrm{GEL}$ & T 7 RAR & T 7 GEL & T 30 RAR & T 30 GEL \\
\hline L.casei & 100,00 & 100,00 & 100,00 & 100,00 & 100,00 & 100,00 \\
\hline S. pasteuri & 100,00 & 100,00 & 100,00 & 100,00 & 100,00 & 100,00 \\
\hline N.mucosa & 100,00 & 100,00 & 100,00 & 100,00 & 100,00 & 100,00 \\
\hline P.aeruginosa & 100,00 & 100,00 & 100,00 & 100,00 & 100,00 & 100,00 \\
\hline P.endodontalis & 100,00 & 100,00 & 100,00 & 100,00 & 100,00 & 100,00 \\
\hline S.sobrinus & 100,00 & 100,00 & 100,00 & 100,00 & 100,00 & 100,00 \\
\hline S.salivarius & 100,00 & 100,00 & 100,00 & 100,00 & 100,00 & 100,00 \\
\hline S.parasanguinis & 100,00 & 100,00 & 100,00 & 100,00 & 100,00 & 100,00 \\
\hline S.moreei & 100,00 & 100,00 & 100,00 & 100,00 & 100,00 & 100,00 \\
\hline S.mutans & 100,00 & 100,00 & 100,00 & 100,00 & 100,00 & 100,00 \\
\hline S.aureus & 100,00 & 100,00 & 100,00 & 100,00 & 100,00 & 100,00 \\
\hline P.putida & 93,75 & 93,75 & 93,75 & 93,75 & 93,75 & 87,50 \\
\hline E.faecalis & 100,00 & 100,00 & 100,00 & 100,00 & 100,00 & 93,75 \\
\hline B.fragillis & 100,00 & 100,00 & 100,00 & 100,00 & 100,00 & 100,00 \\
\hline Aa JP2 & 100,00 & 100,00 & 100,00 & 100,00 & 100,00 & 100,00 \\
\hline P.melaninogenica & 100,00 & 100,00 & 100,00 & 100,00 & 100,00 & 100,00 \\
\hline V.parvula & 100,00 & 100,00 & 100,00 & 100,00 & 100,00 & 100,00 \\
\hline S.sanguinis & 100,00 & 100,00 & 100,00 & 100,00 & 100,00 & 100,00 \\
\hline S.oralis & 100,00 & 100,00 & 100,00 & 100,00 & 100,00 & 93,50 \\
\hline S.mitis & 100,00 & 100,00 & 100,00 & 100,00 & 100,00 & 100,00 \\
\hline S.gordonii & 100,00 & 100,00 & 100,00 & 100,00 & 100,00 & 100,00 \\
\hline АаATCC & 100,00 & 100,00 & 100,00 & 100,00 & 100,00 & 100,00 \\
\hline E.corrodens & 100,00 & 100,00 & 100,00 & 100,00 & 100,00 & 100,00 \\
\hline C.gingivalis & 100,00 & 100,00 & 100,00 & 100,00 & 100,00 & 100,00 \\
\hline F.nucleatum & 100,00 & 100,00 & 100,00 & 100,00 & 100,00 & 100,00 \\
\hline F.periodonticum & 100,00 & 100,00 & 100,00 & 100,00 & 100,00 & 100,00 \\
\hline P.itermedia & 100,00 & 100,00 & 100,00 & 100,00 & 100,00 & 100,00 \\
\hline P.micros & 100,00 & 100,00 & 100,00 & 100,00 & 100,00 & 100,00 \\
\hline S.constelatus & 100,00 & 100,00 & 100,00 & 93,75 & 100,00 & 100,00 \\
\hline P.gingivalis & 100,00 & 100,00 & 100,00 & 100,00 & 100,00 & 100,00 \\
\hline T. denticola & 100,00 & 100,00 & 100,00 & 100,00 & 100,00 & 100,00 \\
\hline T.forsythensis & 100,00 & 100,00 & 100,00 & 100,00 & 100,00 & 100,00 \\
\hline
\end{tabular}

Quando as amostras dos pacientes foram analisadas comparando-se individualmente cada espécie estudada, em função dos tratamentos realizados (RAR e RAR + gel) e tempos de colheita do biofilme gengival, somente os microrganismos 
Bacteroides fragilis, Eikenella corrodens, e Treponema denticola apresentaram diferenças significantes com relação à contagem $(p<0,05)$. Para o $B$. fragilis e $E$. corrodens, os pacientes submetidos ao tratamento com o gel de metronidazol (Grupo 2) apresentaram uma redução significante na contagem destes microrganismos $(p<0,05)$ no período T 7 (sete dias após o tratamento) quando comparados com o baseline ( $\mathrm{T}-7$, sete dias antes do tratamento). Para a espécie $T$. denticola, foi observada diferença significante $(p<0,05)$ na contagem bacteriana entre os grupos estudados (Grupo RAR e Grupo RAR + GEL) no período T 7 (Figura 23). 


\section{Bacteroides fragilis}

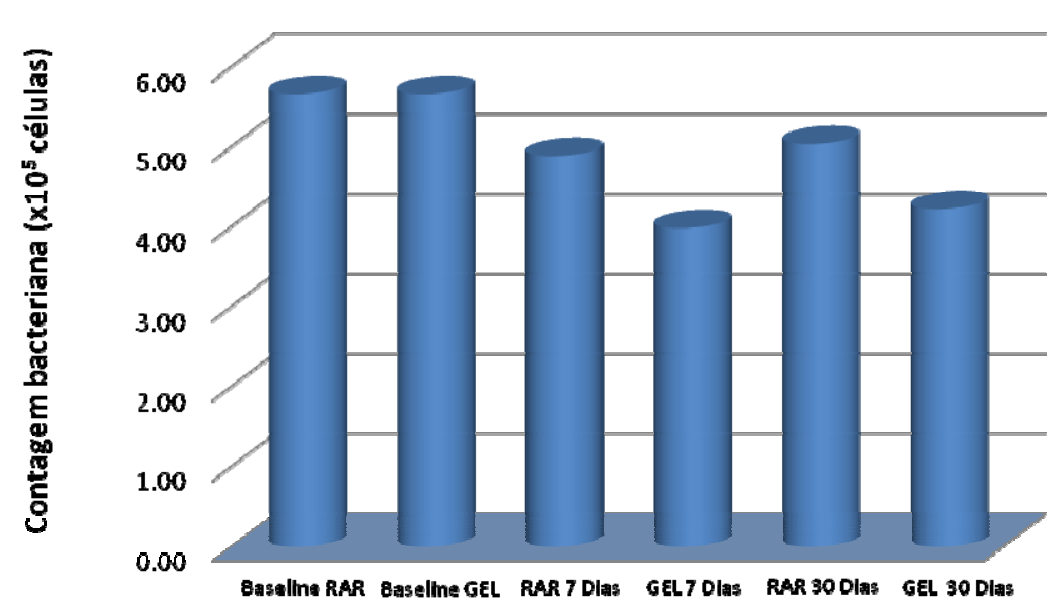

Eikenella corrodens

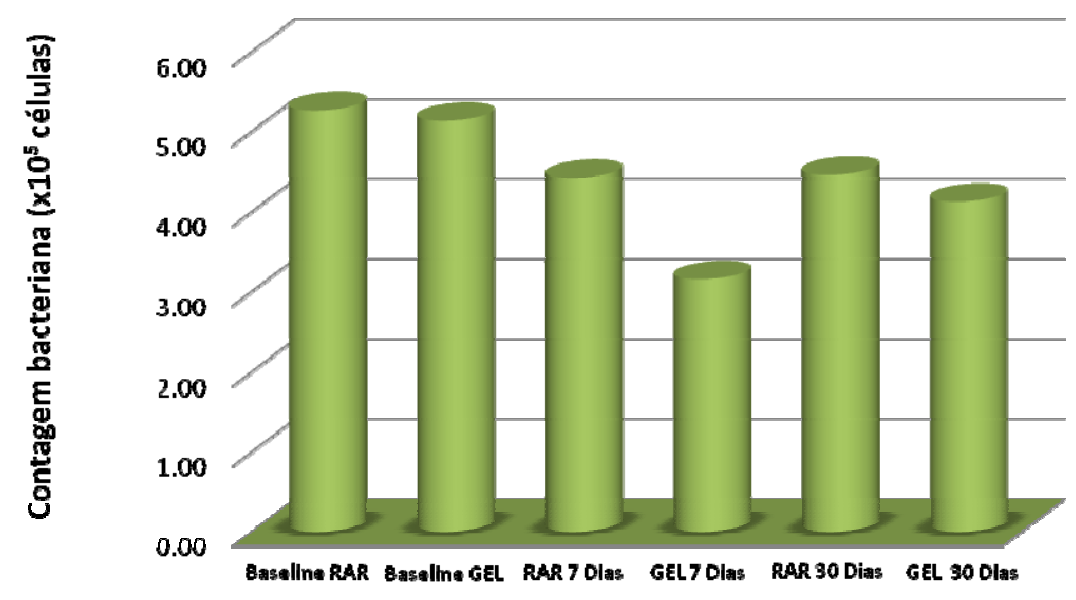

Treponema denticola

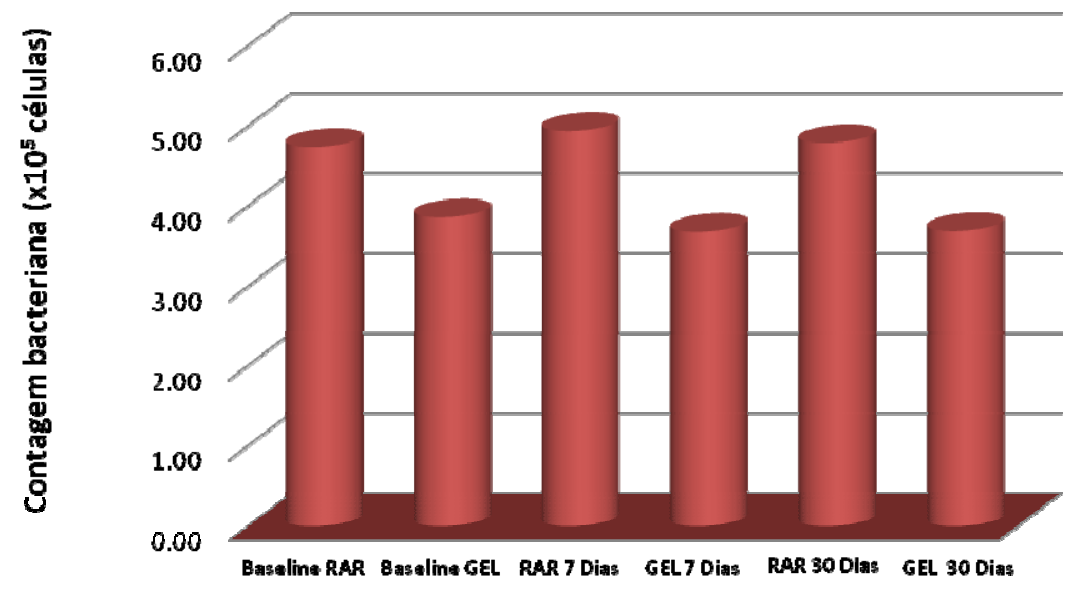

Figura 23. Gráficos da contagem bacteriana $\left(\times 10^{5}\right)$ das espécies que apresentaram diferença significante em relação aos tratamentos e tempos de colheita das amostras. 
6 Discussão 


\section{DISCUSSÃO}

Os avanços no entendimento da etiologia e patogênese das doenças periodontais, e o reconhecimento de que estas são primariamente causadas por bactérias, têm de certa forma, possibilitado o emprego de agentes antimicrobianos sistêmicos ou tópicos como coadjuvantes da consagrada terapia periodontal não cirúrgica convencional.

Dentre as formas farmacêuticas, os sistemas de liberação local de fármacos têm despertado grande interesse, especialmente por minimizar a ocorrência de efeitos adversos observados com a administração sistêmica (VANDEKERCKHOVE; QUIRYNEN; VAN STEENBERGHE, 1998; WILDER, 2003; MOMBELLI; SAMARANAYAKE, 2004).

Para que sejam efetivos, os agentes farmacológicos aplicados intrabolsa periodontal devem atingir o local de ação, mantendo concentrações adequadas por um período de tempo suficiente para permitir a eliminação ou redução de espécies periodontopatogênicas (GOODSON, 1989) que, em algumas situações, podem permanecer após a raspagem e alisamento radicular.

O presente estudo teve como objetivo avaliar os efeitos de um sistema de liberação de fármacos à base de um gel contendo como princípio ativo o metronidazol a 15\%, como auxiliar do tratamento mecânico convencional (RAR) de pacientes portadores de periodontite crônica. Para isso foi realizado o monitoramento das concentrações de metronidazol presentes nas amostras de fluido gengival e análise dos parâmetros clínicos e microbiológicos. 


\subsection{Monitoramento das concentrações de metronidazol}

As concentrações de metronidazol presentes no fluido gengival dos oito pacientes que receberam o gel foram monitoradas para avaliar o tempo máximo que este sistema é capaz de permanecer na bolsa periodontal, liberando uma concentração mínima suficiente para inibir microrganismos relacionados à doença periodontal. Para isso, amostras de fluido gengival foram colhidas em diferentes intervalos de tempo e analisadas quanto à concentração de fármaco presente.

O método de colheita das amostras de fluido gengival para quantificação do fármaco, utilizando tiras de papel filtro, foi escolhido neste estudo por ser atualmente o mais utilizado e aceito para esta finalidade (STOLTZE, 1992; 1995; KIM et al., 2004; SATO, 2006).

Após ser colhido, o volume presente nas tiras de papel deve ser quantificado, para que a concentração do fármaco em cada amostra possa ser calculada. O método mais confiável na atualidade (DEINZER, R.; MOSSANEN, B. S.; HERFORTH, 2000), e por este motivo selecionado para este experimento, é realizado por meio do aparelho Periotron $8000^{\circledR}$ (Figura 4), o qual registra a capacitância elétrica da tira de papel filtro, colocada entre as pinças do aparelho. A capacitância aumenta proporcionalmente ao volume de líquido presente, registrando um escore correspondente, que mais tarde é convertido em unidades de volume (no caso, $\mu \mathrm{L}$ ), por meio do software fornecido pelo fabricante (Periotron Professional, Oraflow Inc., Plainview, NY, USA). A partir do volume, pode-se calcular a concentração do fármaco por volume amostrado.

Para a quantificação de fármacos no fluido gengival algumas técnicas foram descritas como, por exemplo, a difusão capilar no ágar (GORDON et al., 1980; NOTTEN; KOEK-VAN OOSTEN; MIKX, 1982) que, segundo Britt;e Pohlod (1986), 
pode apresentar erros na determinação da concentração do metronidazol; e a cromatografia líquida de alta eficiência - CLAE, que vem sendo empregada com sucesso (VAN OOSTEN; NOTTEN; MIKX, 1986; KELLY et al., 2004; KIM et al., 2004; PÄHKLA et al., 2005; STOLLER et al., 1998; STOLTZE, 1992; SATO et al., 2008), e foi escolhida para ser utilizada nesta pesquisa.

O método analítico da concentração de metronidazol por CLAE foi previamente validado para esta finalidade por Sato (2006), demonstrando que esta forma de análise possui uma adequada especificidade na determinação do metronidazol, ou seja, nenhuma outra substância interferente, presente na formulação do gel, pôde ser observada no mesmo tempo de retenção do metronidazol. Além disso, foi observada uma boa linearidade no intervalo utilizado para a confecção da curva analítica.

No presente estudo um sistema de liberação de metronidazol à base de um gel de poloxamer 407 foi selecionado, sobretudo por ter sido previamente avaliado in vitro e in vivo, demonstrando boa atividade antimicrobiana e biocompatibilidade (GABARRA, 2002; SATO, 2006) e por apresentar um baixo custo em relação aos demais sistemas de liberação de fármacos disponíveis comercialmente.

Em testes laboratoriais, este sistema foi capaz de liberar o fármaco por um tempo prolongado, de 9 a 13 dias (GABARRA, 2002). Em contrapartida, quando testado em um modelo animal, não produziu resultados tão satisfatórios (SATO et al., 2008).

No estudo aqui apresentado, a formulação testada (Tabela1), não foi capaz de liberar o fármaco por um período de tempo prolongado. Os dados obtidos pela CLAE revelaram que o fármaco foi encontrado em altas concentrações apenas 
imediatamente após a aplicação do gel. Após 1 hora houve um decréscimo considerável na quantidade de metronidazol presente nas amostras de fluido gengival, mas ainda assim, exibiu uma média de concentração efetiva $(398,93$ $\mu \mathrm{g} / \mathrm{mL}$ ) para atingir a maioria das espécies anaeróbias, que segundo Walker et al. (1981),é inferior a $8 \mu \mathrm{g} / \mathrm{mL}$.

Entretanto, é importante destacar que algumas bactérias são mais resistentes quando organizadas em um biofilme, sendo que, nesses casos, a concentração de fármaco necessária para eliminar ou impedir o crescimento de certas espécies pode ser até 250 vezes maior (SEDLACEK; WALKER, 2007).

Depois de 48 horas da aplicação do gel nas bolsas periodontais, e colheita do fluido gengival, apenas uma amostra foi positiva para o metronidazol, e em concentração próxima à zero, indicando que a liberação do agente antimicrobiano possivelmente ocorreu de forma rápida e progressiva, dentro de poucas horas (Tabela 3).

Os resultados desta pesquisa in vivo são discrepantes quando comparados aos resultados obtidos no estudo in vitro de Gabarra, 2002, o qual demonstrou um padrão de liberação mais favorável do metronidazol, promovendo uma liberação mais lenta e prolongada do fármaco, que pôde ser detectado por até 13 dias. Cabe ressaltar que no trabalho de Gabarra (2002) foi utilizada uma bolsa periodontal artificial, cujo fluido gengival foi simulado pelo uso de saliva artificial. A saliva artificial, com pH neutro, é composta na maioria das vezes por cloretos, fosfatos, fluoretos, glicerina e água.

O fluido gengival, por sua vez, é o resultado da interação entre o biofilme bacteriano aderido à superfície do dente e as células do tecido periodontal, constituído por uma complexa mistura de substâncias derivadas do soro sanguíneo, 
leucócitos, células estruturais do periodonto e microrganismos bucais (CHAMPAGNE, 2003; UITTO; OVERALL; MCCULLOCH, 2003). Estes componentes podem ter reagido com os produtos do sistema de liberação de fármaco de forma a diminuir o seu tempo de retenção no local, contribuindo para uma liberação acelerada ou até mesmo para a reabsorção da matriz do sistema por enzimas, frequentemente encontradas em concentrações aumentadas no fluido gengival de pacientes com periodontite. Outros fatores relacionados às diferentes características de um estudo in vivo em relação à avaliação in vitro, conhecidos ou não, podem ser responsáveis pelos resultados discordantes entre o presente estudo e o de Gabarra (2002).

Outra pesquisa in vitro na qual foi avaliada a persistência de um gel de metronidazol a 0,005\%, cuja formulação foi baseada neste mesmo polímero, o Lutrol F 127 (poloxamer 407), apresentou resultados semelhantes a esta pesquisa. Os autores Sosnik e Cohn (2004) demonstraram que este sistema liberou todo o metronidazol em apenas 2 dias, tempo máximo em que o metronidazol pôde ser detectado também no presente estudo.

Embora a avaliação in vitro do perfil de liberação de um fármaco seja uma etapa fundamental durante o desenvolvimento de um sistema de liberação intrabolsa periodontal (GABARRA, 2002; BRUSCHI et al., 2007), para que o sistema seja considerado realmente efetivo, promovendo uma liberação prolongada do fármaco e em concentrações adequadas para que sejam obtidos resultados clínicos satisfatórios, ele deve ser testado in vivo.

Sato et al. (2008) motivados pelos bons resultados laboratoriais alcançados com o uso do gel à base do poloxamer 407 (Lutrol ${ }^{\circledR} \mathrm{F}$ 127), no trabalho de Gabarra (2002), avaliaram este sistema de liberação de fármacos em bolsas 
periodontais de cães, e similarmente a esta pesquisa, o metronidazol não foi detectado após $48 \mathrm{~h}$ da aplicação do gel. Embora tenha sido relatado pelos autores que poucas diferenças clínicas e microbiológicas são observadas entre a periodontite no animal e no homem, nos cães, a profundidade das bolsas periodontais obtida com a periodontite induzida, foi no máximo $4 \mathrm{~mm}$. Este fato poderia ter sido uma das causas relacionadas à deficiente retenção do gel no sítio de ação, e um dos fatores que impulsionaram a continuidade da pesquisa, desta vez em humanos, nos quais foram avaliadas bolsas com profundidade $\geq 5 \mathrm{~mm}$. Além disso, o desenho experimental utilizado no citado estudo (splith mouth) não se mostrou adequado para este tipo de experimento, tendo em vista a absorção sistêmica do metronidazol, comprovada pelos autores.

Entretanto, neste estudo, os resultados da permanência do gel podem de certa forma, ser considerados menos favoráveis aos resultados observados nos cães, no trabalho de Sato et al. (2008). Após 48 h, somente uma amostra apresentou uma concentração detectável do metronidazol $(0,35 \mu \mathrm{g} / \mathrm{mL})$, enquanto que no estudo de Sato et al. (2008), neste mesmo tempo, 8 amostras foram positivas para o fármaco em questão e em concentrações mais elevadas (média de 3,08 $\mu \mathrm{g} / \mathrm{mL})$. Uma explicação plausível para esta diferença nos resultados entre os dois trabalhos, é que nos cães, uma dieta pastosa foi instituída e nenhum procedimento de higiene oral foi realizado durante todo o experimento, enquanto que, no presente estudo, todos os pacientes receberam instruções de higiene oral na consulta inicial, e foram motivados a manterem estes procedimentos durante toda a pesquisa. Sendo assim, o fato do paciente realizar as escovações diárias, além de nenhum tipo de restrição alimentar ter sido estabelecido, podem ter contribuído de sobremaneira para eliminação mais expressiva do sistema de liberação de fármaco das bolsas 
periodontais dos pacientes, em comparação com os resultados observados nos cães.

Outro estudo no qual foi realizado o monitoramento da concentração de metronidazol em bolsas periodontais, após a aplicação de um gel com $25 \%$ do fármaco, foi descrito por Stoltze em 1992. Setenta e duas amostras, colhidas de 12 pacientes, foram avaliadas em intervalos de 4, 8, 12, 24 e 36 horas após a aplicação do sistema. Os resultados obtidos por CLAE demonstraram que até 12 horas depois da aplicação do gel o metronidazol pode ser detectado em $100 \%$ das amostras, caindo para $75 \%$ após 24 horas, mas o tempo máximo em que o fármaco foi detectado foi de 36 horas, em uma freqüência de $8 \%$ das amostras, enquanto que no presente estudo, o tempo máximo que se pode observar metronidazol foi de $48 \mathrm{~h}$. Entretanto, neste estudo o metronidazol só foi encontrado em $100 \%$ das amostras imediatamente após a aplicação do gel, caindo para 93,75\% de frequência após $1 \mathrm{~h}$ e $6,25 \%$ após $48 h$.

Os resultados divergentes observados entre os dois estudos podem ser justificados, além de alguns fatores relativos à metodologia, pelas diferenças na composição dos sistemas utilizados. Neste estudo foi utilizado um polímero, o Lutrol $^{\circledR}$ F127 (poloxamer), contendo 15\% de metronidazol, enquanto que no trabalho de Stoltze, foi utilizado um gel à base de monoleato de glicerol e triglicídeos, com metronidazol numa concentração de $25 \%$.

Esposito et al. (1996), após comparar in vivo duas formulações semelhantes contendo tetraciclina, em relação ao tempo de permanência na cavidade oral, relataram que o gel à base de poloxamer 407 desapareceu completamente após $1 \mathrm{~h}$, enquanto que o sistema contendo monoleato de glicerol persistiu por até $8 \mathrm{~h}$. 
O poloxamer 407 tem sido bastante utilizado no desenvolvimento de sistemas de liberação controlada de fármacos (ESPOSITO et al., 1996; PAAVOLA, YLIRUUSI, ROSENBERG,1998; SCHERLUND et al., 2000; KELLY et al., 2004; BRUCSHI, 2006; TIWARI, TIWARI, RAI, 2010), especialmente por apresentar certas características como termo-sensibilidade (passando do estado líquido para gel em contato com a temperatura corporal, permitindo uma liberação mais lenta do fármaco), baixa toxicidade, aumento da solubilização de certos fármacos pouco solúveis em água e facilidade na aplicação quando utilizado na forma injetável. No entanto, a utilização isolada deste polímero na formulação dos sistemas de liberação não está bem estabelecida (DUMORTIER et al., 2006).

Alguns estudos na literatura têm demonstrado que a adição de substâncias mucoadesivas às formulações contendo o poloxamer 407, como octilcianocrilato, o Carbopol $934^{\circledR}$, ou a hidroxietilcelulose, podem produzir efeitos satisfatórios, permitindo a liberação de fármacos na bolsa periodontal por um período bastante prolongado. (KELLY et al., 2004; SOSNICK, COHN, 2004; BRUSCHI et al., 2007; TIWARI, TIWARI, RAI, 2010). No presente estudo, o poloxamer 407 foi utilizado como único meio carreador do metronidazol, e nenhuma outra substância com propriedade adesiva foi adicionada à formulação do gel, o que poderia justificar a baixa efetividade desta composição em liberar o fármaco por um período adequado.

A baixa capacidade de adesão observada com o poloxamer 407 , neste estudo, somada à taxa de renovação do fluido gengival, que pode variar de 20 a 137 $\mu \mathrm{L} / \mathrm{h}$ (GOODSON et al., 2003) dependendo da severidade do processo inflamatório, devem ter exercido um papel fundamental na eliminação do fármaco da bolsa periodontal em um espaço de tempo tão curto. 


\subsection{Parâmetros clínicos}

Os efeitos nos parâmetros clínicos após aplicação do gel de metronidazol a $15 \%$ em bolsas periodontais de indivíduos com periodontite crônica foram avaliados com o objetivo de testar se o uso local de antibióticos como terapia coadjuvante é superior ao tratamento não cirúrgico convencional (RAR).

Para a tomada e o registro das medidas de profundidade de sondagem e nível clínico de inserção dos sítios monitorados foi utilizado o sistema de sondagem computadorizado, Florida Probe ${ }^{\circledR}$. Este sistema foi desenvolvido por Gibbs et al., 1988, e tem sido utilizado em trabalhos científicos por permitir uma pressão de sondagem constante $(20 \mathrm{~g})$, minimizando erros durante os procedimentos de sondagem, além de realizar registros com até $0,2 \mathrm{~mm}$ de variação (BERNARDO et al., 2007; NIEDERMAN, 2009).

Considerando-se que o parâmetro clínico nível de inserção gengival ( $\mathrm{NCl})$ é a variável primária na determinação da progressão da periodontite (PAGE; DEROUEN, 1992; PIHLSTROM, 1992; ARMITAGE, 1996; MAGNUSSON, 1996), e que os resultados dos níveis de inserção gengival não demonstraram diferenças entre os tratamentos (apenas entre os tempos), pode-se concluir que não puderam ser evidenciadas diferenças entre o tratamento feito apenas com a RAR e o que associou a RAR com o gel de metronidazol experimental.

Somente pôde-se observar uma melhora significante dos indicadores clínicos da periodontite ao longo do tempo. A redução na profundidade à sondagem e ganho no nível clínico de inserção, ocorreu nos dois grupos de maneira semelhante, sendo que no grupo tratado com o gel (Grupo 2) os valores de profundidade à sondagem (PS) e nível clínico de inserção (NCI) foram sempre maiores, muito provavelmente porque nesse grupo os pacientes, desde o início do 
acompanhamento longitudinal, tinham dentes com bolsas de maior profundidade e maior perda de inserção que nos pacientes do grupo que recebeu apenas a terapia mecânica (Grupo 1).

Estes resultados estão de acordo com estudos que mostraram dados clínicos equivalentes entre a terapia mecânica convencional ou associada à aplicação local do metronidazol (RIEP; PURUCKER; BERNIMOULIN, 1999; JANSSON; BRATTHALL; SODERHOLM, 2003; PERINETTI et al., 2004; LEIKNES et al., 2007; SINGH et al., 2009).

Alguns autores relataram encontrar diferenças significantes favoráveis ao uso do metronidazol local como adjunto da terapia mecânica, mas não chegaram a concluir se havia significância clínica nesta associação (LIE; BRUUN; BÖE, 1998; STELZEL; FLORÈS-DE-JACOBY, 2000). A maioria destes estudos avaliou o uso de um gel de metronidazol a $25 \%$, que foi comercializado como Elyzol ${ }^{\circledR}$, normalmente empregado em duas sessões. Atualmente este produto não está mais disponível devido à dificuldade de se provar sua eficácia.

$\mathrm{Na}$ pesquisa realizada por Griffths et al. (2000), o uso do Elyzol ${ }^{\circledR}$ como adjunto da raspagem e alisamento radicular foi capaz de promover melhoras significantes nos parâmetros clínicos avaliados. A redução na profundidade de sondagem e o ganho de inserção clínica foram estatisticamente superiores aos resultados observados com a RAR isolada. Os próprios autores atribuíram estes resultados superiores obtidos com o gel de metronidazol ao tempo gasto na instrumentação periodontal, e indagaram sobre o possível efeito de uma instrumentação menos eficiente na supervalorização de resultados obtidos após o emprego de antimicrobianos locais. Também foi comentado que o grande número de 
sítios avaliados pode ter contribuído para os resultados discrepantes em relação a vários estudos em que é empregado um número menor de amostras.

Outro estudo no qual o metronidazol foi utilizado associado à RAR e promoveu melhores resultados do que a RAR isolada foi o de Hitzig et al., 1994. Os autores demonstraram uma melhora com os dois tratamentos, porém os resultados foram significantemente favoráveis à associação RAR +gel. A grande diferença é que como alternativa ao gel, eles usaram uma esponja impregnada com o metronidazol a $5 \%$, que pode ter influenciado para uma resposta mais eficiente com este tipo de sistema de liberação de fármacos, em relação ao gel de metronidazol empregado neste estudo. Recentemente, Singh et al., (2009), fazendo uso desta mesma esponja contendo metronidazol não observaram diferença significante entre a RAR e a RAR + metronidazol, no que diz respeito aos parâmetros clínicos.

No presente estudo, os resultados da comparação entre os pares (grupo x tempo) exibiram diferença estatística entre os Grupos 1 e 2, em relação aos parâmetros clínicos profundidade de sondagem e nível clínico de inserção, apenas no T 7. Este resultado pode ser explicado pela menor redução na PS, em relação ao baseline, e maior média de $\mathrm{NCl}$, observadas neste mesmo tempo no Grupo 2 (RAR + Gel), quando comparado ao grupo1 (RAR), sendo que neste grupo, a redução na PS no T 7 foi significante em relação ao baseline. Nos outros tempos de avaliação clínica (T 30 e T 90), não foi observada diferença significante entre os grupos, e ambos exibiram uma redução progressiva da $\mathrm{PS}$ e $\mathrm{NCl}$ até o final do estudo, que foi considerada significante quando comparada ao baseline (Tabelas 4 e 5).

As diferenças observadas entre os grupos sete dias após as terapias, parecem ter pouca relevância clínica, pois de acordo a American Academy of Periodontology, 1997 (citado por Greenstein, 2000), o restabelecimento da saúde 
periodontal pode ser evidenciado clinicamente a partir de quatro a seis semanas após a instituição da terapia, sendo às vezes necessário um período mais longo para que a melhora dos parâmetros clínicos possa ser evidenciada. Normalmente, este período está relacionado ao início da fase de manutenção, ou seja, 90 dias (Griffithis et al., 2000).

Neste sentido, três meses após os tratamentos ( $T$ 90), pôde ser observada neste estudo, a redução significante em relação ao baseline, nas medidas de PS e NCl, nos dois grupos. O grupo 1 (RAR) exibiu uma redução na PS e $\mathrm{NCl}$ de 1,96 mm e 1,62 mm, respectivamente, enquanto que no Grupo 2 (RAR + Gel) a redução na PS e $\mathrm{NCl}$ foram de 2,24 mm e 1,886 mm, respectivamente.

Estes resultados sugerem que os grupos foram equivalentes e comportaram-se de maneira semelhante, tanto na redução como no ganho de inserção clínica, não obstante o Grupo 2 ter apresentado uma maior redução em ambos os parâmetros. Isso ocorreu porque, geralmente, em bolsas mais profundas a redução na $\mathrm{PS}$ e o ganho no $\mathrm{NCl}$, após a terapia periodontal, são mais pronunciados. Sítios com PS iniciais maiores do que $6 \mathrm{~mm}$ podem exibir uma redução de 2 a 2,5 mm, enquanto que bolsas com profundidade moderada (4 a 6 $\mathrm{mm}$ ) tendem a apresentar de 1 a $1,5 \mathrm{~mm}$ de redução na profundidade à sondagem. (MORRISON; RAMFJORD; HILL, 1980; BADERSTEN; NILVEUS; EGELBERG, 1981, 1984; KALDAHL et al., 1988)

Em relação ao emprego do metronidazol, Stelzel e Florés de Jacoby (1996) detectaram reduções na PS de 1,0 mm com a RAR e 1,3 mm com a RAR + gel, sendo que os resultados foram mais favoráveis ao emprego do fármaco. Quando comparado ao presente estudo, no qual a associação entre os tratamentos foi semelhante à RAR isolada, pode ser observado que ambos apresentaram ao final 
das avaliações, a mesma diferença $( \pm 0,3 \mathrm{~mm})$ na redução da PS entre os dois tratamentos (RAR e RAR + gel). Sendo assim, o que pode ter contribuído para estes resultados distintos entre os dois estudos, pode estar relacionado às medidas de PS iniciais, considerando-se a diferença na magnitude da redução da PS observada entre as pesquisas.

No que diz respeito ao nível clínico de inserção tem sido demonstrado que após o tratamento convencional, o ganho de inserção em bolsas profundas $(6 \mathrm{~mm})$ é de aproximadamente 1,2 mm (FAVERI et al., 2006). Bernardo et al., 2007 demonstraram que bolsas com profundidade à sondagem $\geq 7 \mathrm{~mm}$ chegaram a ter um ganho no $\mathrm{NCl}$ de até 1,4 mm após a terapia periodontal. De fato, no estudo aqui apresentado, as reduções nas medidas de $\mathrm{NCl}$ dos grupos avaliados (RAR e RAR + gel) foram maiores do que normalmente observadas nos estudos, mas estes resultados relativamente distintos podem estar relacionados não só as medidas iniciais de PS, mas também às diferentes metodologias empregadas numa pesquisa clínica, o que dificulta a comparação direta entre os estudos.

\subsection{Parâmetros microbiológicos}

Tendo em vista a natureza bacteriana das periodontites, a análise microbiológica é de fundamental importância na avaliação da efetividade da terapia periodontal. A técnica de diagnóstico molecular que utiliza sondas de DNA genômico, denominado método da hibridização DNA Checkerboard foi descrita inicialmente por Socransky et al., 1994, e tem sido utilizada em diversos estudos, especialmente em estudos clínicos na área de periodontia. (HAFFAJJE et al., 1997; FERES et al., 2001; SOCRANSKY et al., 1998; 2004; HAFFAJEE et al., 2004; LÓPEZ et al., 2006; HAFFAJEE; PATEL, SOCRANSCKY, 2008). 
As técnicas tradicionais de cultura não permitem que sejam realizados estudos em larga escala que possam identificar os complexos ecossistemas microbiológicos. Além disso, devido à dificuldade de se cultivar bactérias anaeróbias, muitas vezes parte da microbiota subgengival é subestimada. O método DNA Chekerboard permite identificar microrganismos de difícil cultivo, possibilitando o diagnóstico quantitativo e simultâneo de um grande número de espécies em várias amostras. É uma técnica rápida, quando comparada aos métodos tradicionais de cultura, sensível, e permite um melhor conhecimento sobre a microbiota periodontal, assim como o efeito das terapias periodontais na composição e manutenção dos biofilmes (SOCRANSKY et al., 2004)

Desta forma, o uso da técnica de hibridização DNA Checkerboard neste estudo, permitiu a avaliação de 32 espécies bacterianas na microbiota subgengival de 16 pacientes portadores de periodontite crônica, antes e após sete e 30 dias da instituição das terapias de RAR e RAR + gel de metronidazol. A maioria dessas espécies foi selecionada por serem consideradas as primeiras colonizadoras do biofilme bacteriano dentário ou por seus potenciais papéis no surgimento e desenvolvimento das doenças periodontais (ZEE et al.,1996; SOCRANSKY et al., 1998).

Os dados microbiológicos do presente estudo mostraram que os dois Grupos (1-RAR e 2-RAR + gel) possuíam inicialmente (baseline- T-7) um perfil de colonização compatível com periodontite crônica, com níveis elevados de espécies do complexo laranja e, principalmente, do complexo vermelho. A espécie $A$. actinoycetemcomitans sorotipo b considerada um patógeno importante foi uma das que apresentaram as maiores contagens em ambos os grupos, do início ao final do estudo (Figura 22). 
Quando os grupos foram comparados, levando-se em consideração o tempo, foi encontrada uma discreta diferença, porém significante, entre os grupos no baseline, sendo que os pacientes pertencentes ao Grupo 2 exibiram uma menor contagem no total de bactérias (tabela 6).

Durante a seleção dos pacientes para compor os grupos avaliados neste estudo, vários critérios de inclusão e exclusão foram utilizados (material e métodos, item 4.1) no intuito de reduzir possíveis fatores interferentes, sistêmicos ou ambientais, que pudessem deturpar os resultados do estudo. Todavia, apenas o exame clínico-periodontal por meio de sondas manuais foi realizado para inclusão dos pacientes no estudo, e, portanto, a composição da microbiota subgengival destes pacientes era desconhecida, não sendo possível prever as diferenças encontradas entre os grupos previamente ao tratamento. Além disso, a distribuição dos indivíduos em seus respectivos grupos foi feita aleatoriamente, como preconizada para estudos científicos.

Da mesma forma que no baseline, nos tempos T 7 e T 30, o grupo tratado com gel de metronidazol apresentou valores de contagens bacterianas estatisticamente inferiores ao grupo tratado apenas com a RAR. Porém, as diferenças tiveram um nível de significância maior nestes dois tempos (Tabela 6), sugerindo que, embora os valores da contagem bacteriana tenham sido diferentes também no baseline, o que consequentemente, poderia produzir resultados distintos nos demais tempos, estas diferenças foram mais evidentes após os tratamentos (tabela 6 e figura 22).

Isso indica que de certa forma o uso do metronidazol como adjunto do tratamento mecânico foi mais eficiente. Sendo assim, as menores contagens no total de células bacterianas observadas nas amostras do grupo 2 (RAR + Gel), nos 
tempos T 7 e T 30, podem ter ocorrido em virtude da atividade antimicrobiana do metronidazol, que embora tenha permanecido na bolsa periodontal em uma concentração relativamente efetiva por um curto período de tempo, no caso por 1 hora, pode ter atuado sobre algumas bactérias mais susceptíveis. A redução, embora nem sempre significante, de algumas espécies após o uso do gel, deve ter cooperado para as diferenças detectadas nos resultados entre os grupos, em favor do uso do gel de metronidazol.

A superioridade em promover melhoras nos parâmetros microbiológicos com o uso de antibióticos locais independentes ou associados à terapia mecânica (RAR), em relação ao emprego da RAR isolada, foi relatada em alguns estudos da literatura. (PEDRAZZOLI, KILIAN, KARRING, 1992; PERINETTI et al., 2004; BOGREN et al., 2008; PAOLANTONIO et al., 2008; SINGH et al., 2009).

Outros estudos têm observado baixa efetividade destes agentes sobre a microbiota patogênica, ou limitados benefícios quando comparados à RAR isolada (RUDHART et al., 1998; RIEP, PURUCKER, BERNIMOULIN, 1999; JANSSON et al., 2004; JANATOVÁ et al., 2009).

Uma comparação direta dos resultados deste estudo com outros da literatura não é viável, devido a grande variedade de metodologias que podem ser empregadas em uma análise microbiológica, como por exemplo: número de amostras utilizadas, microrganismos avaliados, técnicas de colheita do biofilme, tipos de terapias realizadas, tempos de avaliação, gravidade da doença, entre outros fatores.

De acordo com ROONEY et al. (2002), os resultados controversos nos achados microbiológicos entre os estudos que avaliam a combinação de terapias no tratamento periodontal, são devidos aos diferentes fatores de variação empregados, 
como os descritos acima. Também foi relatado pelos autores que os métodos de cultura podem subestimar a presença, assim como o número de bactérias, e os métodos moleculares tendem a exibir altas contagens bacterianas.

Além disso, mesmo sendo encontradas diversas pesquisas relacionadas ao uso dos sistemas de liberação de fármacos na bolsa periodontal, poucas avaliaram os efeitos de um gel de metronidazol na microbiota subgengival. Ainda assim, serão feitas algumas considerações acerca das diferenças ou semelhanças nos resultados deste estudo com alguns da literatura que avaliaram a microbiota subgengival após o uso de sistemas de liberação de fármacos.

Pedrazzoli, Kilian e Karring (1992) comparando os efeitos nos parâmetros microbiológicos de um gel de metronidazol a $25 \%$ e da RAR, ambos aplicados em quadrantes diferentes da boca, observaram que o tratamento com o gel de metronidazol produziu uma significante alteração da composição bacteriana subgengival, com diminuição dos anaeróbios pigmentados de preto, incluindo a espécie $P$. intermédia. Ambos os tratamentos reduziram o número de espiroquetas e aumentaram a proporção de estreptococos. Entretanto a RAR isolada permitiu um aumento na proporção de $A$. actinomycetemcomitans, e foi considerada pelos autores menos eficiente do que o uso do gel.

Outro estudo no qual os efeitos sobre a microbiota subgengival foram avaliados e comparados após a aplicação local de um gel de metronidazol a 1\%, um gel de clorexidina a $1 \%$ e um gel placebo, posteriormente à terapia mecânica, foi o de Perinetti et al. (2004). Os autores observaram uma redução significante de 12 espécies bacterianas com o gel de metronidazol, 18 com o gel de clorexidina e 4 com o gel placebo. Além disso, nos grupos tratados com fármaco (metronidazol ou clorexidina), as espécies periodontopatogênicas, $A$. actinimycetemcomitans, $P$. 
intermédia, P. gingivalis e V. parvula exibiram uma redução significante, mas o mesmo não foi observado para o grupo que recebeu o gel placebo, indicando que o uso de antimicrobianos locais como adjunto da instrumentação mecânica pode ser mais efetivo que a RAR na redução de patógenos específicos.

No presente estudo, apesar do uso do gel de metronidazol associado à RAR ter demonstrado uma maior efetividade na redução do número total de espécies em relação à RAR isolada nos tempos T 7 e T 30, não pôde ser observada a eliminação de nenhuma das espécies periodontopatogênicas, nem mesmo a redução na incidência destas espécies com nenhum dos tratamentos (Tabela 7).

A análise individual das espécies mostrou diferença significante entre os grupos, somente para a espécie $T$. denticola (potencial patógeno periodontal), sete dias após as terapias. Porém, o Grupo 2 (RAR + Gel de metronidazol) não apresentou redução significante na contagem desta espécie neste mesmo tempo ( $T$ 7), e além do mais, a contagem desta bactéria já era reduzida (sem significância) no baseline, em comparação ao grupo1 (RAR). Estes resultados conduzem a acreditar que o tratamento com o gel de metronidazol teve pouca influência sobre esta espécie patogênica (Figura 23).

Os resultados relatados por Pedrazzoli; Kilian e Karring (1992) e Perinetti et. al. (2004) mostraram mudanças mais expressivas, comparados à este estudo, no sentido de promover a redução dos patógenos periodontais, após o uso local do metronidazol. Além de algumas diferenças na metodologia, o que certamente produziu os resultados distintos entre os estudos, foi que neste, o gel de metronidazol a $15 \%$ foi aplicado apenas uma vez, justamente para testar a duração e os efeitos clínicos e microbiológicos de uma única aplicação do gel. Nos outros dois estudos foram realizadas aplicações repetidas, sendo que Pedrazzoli; Kilian e 
Karring (1992) aplicaram o gel duas vezes, com um intervalo de 7 dias, e a concentração do metronidazol era maior, $25 \%$.

Já Perinetti et al, (2004), embora tenham utilizado uma concentração bem inferior (1\%) do fármaco, fizeram quatro aplicações consecutivas do gel, durante 4 semanas. Estes diferentes regimes de uso do metronidazol podem ter contribuído, para as diferenças observadas entre os estudos.

Diante dos dados do presente estudo, pode-se inferir que os tratamentos com a RAR e a RAR associada ao gel de metronidazol demonstraram eventuais diferenças significantes, porém, exibiram um comportamento semelhante no que diz respeito aos patógenos periodontais.

Neste caso seria ilusório afirmar que o tratamento coadjuvante com o gel de metronidazol foi absolutamente superior à RAR isolada. Outras semelhanças nos parâmetros microbiológicos entre os dois tratamentos também foram relatadas por Riep; Purucker e Bernimoulin, (1999), ao avaliar o gel contendo metronidazol a 25\%. No entanto, os autores demonstraram redução significante para algumas bactérias patogênicas com os dois tratamentos.

Uma observação intrigante no presente estudo, foi que no grupo que recebeu apenas a RAR, não houve uma redução significante na contagem do total de espécies avaliadas após o tratamento. Os níveis das espécies consideradas patogênicas ou possíveis patógenos relacionados à periodontite, como as do complexo vermelho ( $P$. gingivalis, $T$. Forsythensis, $T$. denticola,), laranja (S. constelatus, P. micros, P. intermédia, F. periodonticum e F. nucleatum) e as espécies actninomycetemcomitans a e b, permaneceram praticamente inalteradas e em concentrações relevantes nos três tempos de avaliação (Figura 23). O mesmo 
pôde ser observado com bactérias menos relacionadas à doença periodontal como, por exemplo, algumas espécies de estreptococos.

Estes resultados são divergentes em comparação a vários relatos na literatura, nos quais a RAR foi capaz de reduzir o número total de bactérias ou ao menos afetar a composição da microbiota subgengival (BADERSTEN; NILVEUS; EGELBERG, 1984; SHILOAH; PATTERS, 1994; HAFFAJEE et al, 1997; KHOSRAVI et al., 2004; CUGINI et al., 2000; CARVALHO et al., 2004; LÓPEZ, 2006).

Entretanto, as limitações desta terapia na flora subgengival foram descritas por Haffajee et al. (1997), ao observar que apenas as espécies do complexo vermelho foram reduzidas após a RAR, e nenhuma das espécies avaliadas, inclusive as do complexo vermelho, foram eliminadas completamente com esta terapia. Segundo os autores, logo após a instituição da RAR, ocorre uma rápida recolonização das bolsas periodontais pela maioria das espécies, inclusive as benéficas, em 1 ou 2 semanas, a níveis comparáveis ao observado antes do tratamento.

De acordo com um trabalho de revisão realizado por Petersilka et al. (2002), o fenômeno da recolonização ocorre devido à permanência de bactérias nas superfícies dentais. Muitas delas, como a A. actinomycetemcomitans, (detectada em altos níveis neste estudo), têm a capacidade de penetrar nos tecidos periodontais, ou mesmo nos túbulos dentinários, (ADRIAENS et al., 1988; MÜLLER, LANGE, MÜLLER, 1993; SANDROS et al., 1994; QUIRYNEN et al., 2001; COLOMBO et al., 2006) e neste caso a instrumentação mecânica pode falhar, especialmente em sítios com maior profundidade de sondagem (RUDNEY et al., 2005).

No caso deste estudo, foram selecionados sítios com profundidade de sondagem entre 5 a $8 \mathrm{~mm}$, sendo que dentes multiradiculares também foram 
incluídos. Estes fatores podem ter dificultado o acesso às bactérias durante a instrumentação por meio da RAR, não produzindo os resultados microbiológicos esperados com esta terapia.

A forma com que a instrumentação mecânica foi conduzida neste estudo, também poderia gerar dúvidas em relação aos reais motivos que levaram à baixa eficiência da RAR em alterar a microbiota subgengival. Tem sido relatado que o tratamento da boca toda realizado em um único estágio promove melhores resultados microbiológicos do que a instrumentação mecânica feita por quadrantes em sessões distintas (QUIRYNEN et al., 1999), reduzindo o risco de recolonização.

Entretanto, estudos mais recentes não conseguiram comprovar essa melhora significativa a favor do tratamento em estágio único (APATZIDOU et al., 2004. ZIJNGE et al., 2010). Mesmo assim, Zijnge et al. (2010) demonstraram uma redução significante para a espécie $T$. denticola com o tratamento em estágio único.

É importante ressaltar que nos estudos acima citados a RAR em estágio único, foi realizada por meio de curetas e no presente estudo apenas nos sítios teste as curetas foram utilizadas, no restante da boca foi realizado o debridamento mecânico por meio de um aparelho de ultrassom. Resultados microbiológicos após instrumentação manual e ultra-sônica sugerem não haver diferença entre as duas técnicas, e a descontaminação radicular de bolsas profundas pode ser efetiva com ambos os instrumentos (BADERSTEN, NILVEUS, EGELBERG, 1984; KHOSRAVI et al., 2004).

Por este aspecto, não seria correto responsabilizar o método empregado na instrumentação mecânica, utilizado neste estudo, à falta de efetividade da RAR na redução da flora subgengival, visto que tanto a RAR realizada em estágio único, quanto a utilização de aparelho ultrasônico para esta finalidade, são preconizadas, 
aparentemente sem prejuízo para a terapia periodontal. No entanto, existem limitados estudos comparando os efeitos destes métodos na microbiota subgengival, não sendo possível concluir com clareza que este fator não tenha contribuído para os resultados aqui apresentados.

Neste estudo, a análise intragrupos demonstrou que após a aplicação do gel houve redução significante no total de espécies avaliadas após sete dias da instituição do tratamento. Porém, as espécies com grande potencial patogênico, $P$. gingivalis, Tanerella forsythensis, Treponema denticola e A. Actinomycetemcomitans não demonstraram redução significante com a instituição da antibioticoterapia local, embora tenham exibido uma contagem inferior ao baseline. Estes resultados estão de acordo com os achados de Jansson et al. (2004), os quais relataram que o tratamento com um gel de metronidazol a $25 \%$ como coadjuvante da terapia convencional, não tem uma influência significante na microbiota patogênica.

Em um estudo realizado por Janatová et al. (2009), a incidência das espécies $T$. forsythia, $P$. gingivalis e $P$. nigrescens foi monitorada em diferentes nichos da cavidade oral de pacientes clinicamente saudáveis, com periodontite, e também em sítios que receberam a aplicação local de dois compostos antibacterianos à base de gel (digluconato de clorexidina e metronidazol a $25 \%$ ). Os autores observaram que o uso local destes antibióticos não foi capaz de produzir uma expressiva redução na microbiota patogênica e relataram que mesmo sítios clinicamente saudáveis de pacientes com periodontite podem servir como reservatório para espécies patogênicas, o que poderia comprometer a efetividade dos tratamentos.

Em contrapartida, Singh et al., 2009 após utilizar uma esponja colágena impregnada com metronidazol, em bolsas periodontais de pacientes com periodontite, 
observaram redução significante na proporção de bactérias gram negativas e um aumento das gram positivas após o uso deste sistema como coadjuvante da terapia convencional, utilizando a técnica da cultura para a análise microbiológica. O método PCR foi utilizado para identificar a presença de patógenos específicos como $T$. forsythensis, A. actinomvcetemcomitans e $P$. gingivalis, confirmando que a incidência destas espécies foi reduzida após o tratamento com o metronidazol.

Entre este estudo e o de Singh et al., 2009, seria possível listar uma série de diferenças relativas à metodologia, que poderiam produzir estes resultados discrepantes quanto à microbiota, após o uso do metronidazol. Uma destas diferenças diz respeito ao tipo de sistema de liberação de fármaco, que neste estudo foi um gel e no deles uma esponja de colágeno. Hitzig et al., 1997, já tinham demonstrado efeitos similares ao estudo citado, após usar este dispositivo contendo $95 \%$ de colágeno e $5 \%$ de metronidazol. Este sistema, ao contrário do que foi observado neste estudo, pode ter permanecido mais tempo que o gel, permitindo uma liberação mais controlada do fármaco, o que deve ter auxiliado na redução das espécies analisadas.

Portanto, uma explicação para a baixa efetividade do gel de metronidazol sobre os patógenos periodontais, observada no presente estudo, pode estar relacionada à breve permanência deste sistema nas bolsas periodontais, o que deve ter impedido a ação do fármaco sobre a maioria das bactérias em um período reduzido de tempo.

Outra justificativa, digna de nota, foi que a instrumentação mecânica, instituída neste estudo não foi capaz de alterar o ambiente subgengival, o que favoreceria a atuação do metronidazol nos microrganismos, tendo em vista que a instituição da terapia antibiótica local como coadjuvante do tratamento convencional tem sido proposta para potencializar a eficácia do debridamento periodontal 
(BONITO et al., 2005; BOGREN et al., 2008), agindo sobre um biofilme já desorganizado, e, portanto, menos resistente à ação de antimicrobianos (SEDLACEK; WALKER, 2007).

Embora não tenha sido observada eliminação ou diminuição significante das principais espécies periodontopatogênicas com o gel de metronidazol neste estudo, foi observada uma redução significante no tempo $\top 7$, na contagem da espécie $B$. fragilis e da espécie E. corrodens, indicando que estas bactérias foram mais sensíveis ao fármaco durante o período que o gel permaneceu na bolsa periodontal.

A espécie E. corrodens, é um bastonete gram negativo, pertencente ao complexo verde (Socransky et al., 1998), e tem sido associada à periodontite por ser encontrada em maiores proporções em sítios com destruição periodontal ativa (Taner et al., 1987), e em sítios que responderam pobremente ao tratamento periodontal (Hafajee et al., 1988).

O Bacteroides fragilis é um bacilo gram negativo, que faz parte da flora intestinal normal e inclui o patógeno anaeróbio mais encontrado em infecções e abscessos (SIMON; GORBACH, 1984 citado por MONCRIEF et al.,1995). Apesar de ter sido detectado na microbiota gengival (DUERDEN, 1980), sua associação com a doença periodontal ainda é desconhecida, mas segundo Moncrief et al. (1995), esta espécie tem sido associada à destruição tecidual, devido à sua capacidade proteolítica por meio da produção de metaloproteinases.

Da mesma forma, a produção destas enzimas pela E. corrodens foi relatada por Dahan et al., 2001. Sendo assim, a eliminação ou redução destas espécies, como observado neste estudo após o uso do gel, pode ter uma implicação positiva no restabelecimento da saúde periodontal, evitando uma destruição mais severa dos tecidos periodontais. 
Apesar da redução significante na contagem total das bactérias e das duas espécies acima citadas no T 7 (sete dias pós tratamento), trinta dias após a terapia foi observado um leve aumento na contagem das espécies, que não foi considerado significante dos demais tempos. Este aumento era previsto, visto que a recolonização de sítios tratados pode ocorrer em poucas semanas (Haffajee, et al., 1997; Haffajee et al., 2006), principalmente se não houver um padrão de higienização adequado. Além do mais, o gel de metronidazol não ficou tempo suficiente para que fosse evitado o restabelecimento da microbiota no T 30.

Os resultados clínicos e microbiológicos demonstrados neste estudo, não comprovaram que o emprego do gel de metronidazol a $15 \%$ associado à raspagem e alisamento radicular foi superior à RAR isolada. Apesar de não ter sido observada, com quaisquer das terapias, uma alteração significante em relação aos principais patógenos periodontais, ambas foram capazes de promover melhoras clínicas significantes, e, portanto, eficientes no restabelecimento da saúde periodontal.

Uma limitação do presente estudo talvez seja o reduzido número de amostras empregadas nas avaliações clínica e microbiológica. Fatores relacionados à resposta imunológica individual de cada organismo podem ter um impacto fundamental no sucesso dos tratamentos, e neste sentido, um número aumentado de amostras poderia proporcionar resultados mais relevantes quanto à eficácia das terapias empregadas.

Novas formulações para o tratamento adjuvante da periodontite, com melhores características mucoadesivas, que proporcionem uma liberação sustentada de fármacos no sítio doente, devem ser testadas na busca de resultados mais favoráveis com esses sistemas de liberação intrabolsa periodontal. 
7 Conclusões 


\section{CONCLUSÕES}

Diante dos resultados do monitoramento das concentrações do gel de metronidazol nas bolsas periodontais, e dos efeitos nos parâmetros clínicos e microbiológicos após a aplicação deste sistema como auxiliar ao tratamento convencional, pôde-se se concluir que:

1) O sistema de liberação de fármaco à base do poloxamer 407 , como único meio carreador do metronidazol, não foi capaz de manter concentrações efetivas do fármaco por um período prolongado e foi eliminado rapidamente da bolsa periodontal.

2) Ambas as terapias utilizadas neste estudo, RAR e RAR + Gel, foram igualmente eficazes em reduzir a profundidade à sondagem e promover um ganho no nível clínico de inserção, mas o emprego do gel de metronidazol como tratamento adjunto da terapêutica periodontal, não promoveu benefícios clínicos superiores em relação ao emprego da RAR isolada.

3) Quanto aos parâmetros microbiológicos, embora tenha sido detectada alguma diferença significante entre as terapias (RAR e RAR+ Gel), elas tiveram um comportamento semelhante na microbiota subgengival, no que diz respeito aos patógenos periodontais, sendo que com nenhuma delas houve a diminuição significante ou eliminação das principais espécies periodontopatogênicas. 
Referências 


\section{REFERÊNCIAS ${ }^{1}$}

ADDY, M.; RAWLE, L.; HANDLEY, R.; NEWMAN, H. N.; COVENTRY, J. F. The development and in vitro evaluation of acrylic strips and dialysis tubing for local drug delivery. Journal of Periodontology, Chicago, v. 53, n. 11, p. 693-699, Nov. 1982.

ADDY, M.; LANGEROUDI, M. Comparison of the immediate effects on the subgingival microflora of acrylic strips containing $40 \%$ chlorhexidine, metronidazole or tetracycline. Journal of Clinical Periodontology, Copenhagen, v. 11, n. 6, p. 379386, Jul. 1984.

ADDY, M.; HASSAN, H.; MORAN, J.; WADE, W.; NEWCOMBE, R. Use of antimicrobial containing acrylic strips in the treatment of chronic periodontal disease. A three month follow-up study. Journal of Periodontology, Chicago, v. 59, n. 9, p. 557-564, Sep. 1988.

ADRIAENS, P. A. et al. Bacterial invasion in root cementum and radicular dentin of periodontally diseased teeth in humans. A reservoir of periodontopathic bacteria. Journal of Periodontology, Chicago, v. 59, n.4, p. 222-230, Apr. 1988.

AGAN, S.; SONMEZ, S.; SERDAR, M. The effect of topical doxycycline usage on gingival crevicular fluid MMP-8 levels of chronic and aggressive periodontitis patients: a pilot study. International Journal of Dental Hygiene, Oxford, v. 4, n. 3, p. 114121, Aug. 2006.

AHUJA A, ALI J, RAHMAN S. Biodegradable periodontal intrapocket device containing metronidazole and amoxycillin: formulation and characterisation. Die Pharmazie, Berlin, v.61, n.1, p.25-9. Jan. 2006.

AINAMO, J.; LIE, T.; ELLINGSEN, B. H.; HANSEN, B. F.; JOHANSSON, L. A.; KARRING, T.; KISCH, J.; PAUNIO, K.; STOLTZE, K. Clinical responses to subgingival application of a metronidazole $25 \%$ gel compared to the effect of subgingival scaling in adult periodontitis. Journal of Clinical Periodontology, Copenhagen, v. 19, n. 9 (Pt 2), p. 723-729, Oct. 1992.

AKALIN, F. A.; BALTACIOĞLU, E.; SENGÜN, D.; HEKIMOĞLU, S.; TAŞKIN, M.; ETIKAN, I.; FIŞENK, I. A comparative evaluation of the clinical effects of systemic

\footnotetext{
${ }^{1}$ De acordo com:

ASSOCIAÇÃO BRASILEIRA DE NORMAS TÉCNICAS. NBR 6023: informação e documentação: referências: elaboração. Rio de Janeiro, 2002.
} 
and local doxycycline in the treatment of chronic periodontitis. Journal of Oral Science, Tokio, v. 46, n.1, p. 25-35, Mar. 2004.

AMERICAN ACADEMY OF PERIODONTOLOGY;. Position statement and guidelines for soft tissue management programs. Chicago, 1997.

AMERICAN ACADEMY OF PERIODONTOLOGY. The role of controlled drug delivery for periodontitis (Position Paper). Journal of Periodontology, Chicago, v. 71, n. 1, p. 125-140, Jan. 2000.

APATZIDOU DA, RIGGIO MP, KINANE DF. Quadrant root planning versus same day full-mouth planning. II. Microbiological findings. Journal of Clinical Periodontology, Copenhagen, v.31, 2004; 31: 141-48

ARMITAGE, G. C.; JEFFCOAT, M. K.; CHADWICK, D. E.; TAGGART, E. J. JR.; NUMABE, Y.; LANDIS, J. R.; WEAVER, S. L.; SHARP, T. J. Longitudinal evaluation of elastase as a marker for the progression of periodontitis. Journal of Periodontology, Chicago, v.65, n.2, p.120-8, Feb. 1994.

ARMITAGE, G. C. Manual periodontal probing in supportive periodontal treatment. Periodontology 2000, Copenhagen, v.12, p.33-9, 1996.

ARMITAGE, G. C.; ROBERTSON, P. B. The biology, prevention, diagnosis and treatment of periodontal diseases: scientific advances in the United States. The Journal of the American Dental Association, Chicago, v.140, Suppl. 1, p.36S-43S, Sep. 2009.

ARMITAGE, G. C. Comparison of the microbiological features of chronic and aggressive periodontitis. Periodontology 2000, Copenhagen, v. 53, p. 70-88, Jun. 2010.

AVILA-CAMPOS, M. J.; VELASQUEZ-MELENDEZ, G. Prevalence of putative periodontopathogens from periodontal patients and healthy subjects in Sao Paulo, SP, Brazil. Revista do Instituto de Medicina Tropical de São Paulo, São Paulo, v. 44, n.1, p.1-5, Jan-Feb. 2002.

AWARTANI, F. A.; ZULQARNAIN, B. J. Comparison of the clinical effects of subgingival application of metronidazole $25 \%$ gel and scaling in the treatment of adult periodontitis. Quintessence International, Berlin, v. 29, n. 1, p. 41-48, Jan. 1998.

AZMAK, N.; ATILLA, G.; LUOTO, H.; SORSA, T. The effect of subgingival controlledrelease delivery of chlorhexidine chip on clinical parameters and matrix 
metalloproteinase-8 levels in gingival crevicular fluid. Journal of Periodontology, Chicago, v.73, n.6, p. 73: 608-615, Jun. 2002.

AZUMA, M. Fundamental mechanisms of host immune responses to infection. Journal of Periodontal Research, Copenhagen, v.41, p.361-373, 2006.

BADERSTEN, A.; NILVÉUS, R.; EGELBERG, J. Effect of nonsurgical periodontal therapy. I. Moderately advanced periodontitis. Journal of Clinical Periodontology, Copenhagen, v.8, n.1, p.57-72, Feb. 1981.

BADERSTEN, A.; NILVÉUS, R.; EGELBERG, J. Effect of nonsurgical periodontal therapy II. Severely advanced periodontitis. Journal of Clinical Periodontology, Copenhagen, v. 11, n.1, p. 63-76, Jan. 1984.

BERNARDO, C. C.; DE MICHELI, G.; IMBRONITO, A. V.; CARVALHO, V. F.; DEL CIOPPO, C. V. RPG Revista da Pós Graduação, São Paulo, v.13, n.4, p.345-52, 2007.

BOGREN, A.; TELES, R. P.; TORRESYAP, G.; HAFFAJEE, A. D.; SOCRANSKY, S. S., WENNSTRÖM, J. L. Locally delivered doxycycline during supportive periodontal therapy: a 3-year study. Journal of Periodontology, Chicago, v.79, n.5, p. 827-35, May. 2008.

BONITO, A. J.; LUX, L.; LOHR, K. N. Impact of local adjuncts to scaling and root planing in periodontal disease therapy: a systematic review. Journal of Periodontology, Chicago , v.76, n.8, p. 1227-36, Aug. 2005.

BRITT, M. R.; POHLOD, D. J. Serum and crevicular fluid concentrations after a single oral dose of metronidazole. Journal of Periodontology, Chicago, v.57, n.2, p.104-7, Feb. 1986.

BRUSCHI, M. L.; JONES, D. S.; PANZERI, H.; GREMIÃO, M. P.; DE FREITAS, O.; LARA, E. H. Semisolid systems containing propolis for the treatment of periodontal disease: in vitro release kinetics, syringeability, rheological, textural, and mucoadhesive properties. Journal of Pharmaceutical Sciences, Easton, v.96, n.8, p.2074-89, Aug. 2007.

CARRANZA, F.; NEWMAN, G. Periodontia Clínica. 8 ed. Rio de Janeiro: Guanabara Koogan, 1998. p.458.

CARVALHO L, H.; D'AVILA, G. B.; LEÃO, A.; HAFFAJEE, A. D.; SOCRANSKY, S. S.; FERES, M. Scaling and root planing, systemic metronidazole and professional plaque removal in the treatment of chronic periodontitis in a Brazilian population. 
I.Clinical Results. Journal of Clinical Periodontology, Copenhagen, v.31, n.12, p. 1070-6, Dec. 2004.

CARVALHO, L. H.; D'AVILA, G. B.; LEÃO, A.; GONCALVES, C.; HAFFAJEE, A. D.; SOCRANSKY, S. S. Scaling and root planing, systemic metronidazole and professional plaque removal in the treatment of chronic periodontitis in a Brazilian population II - Microbiological Results. Journal of Clinical Periodontology, Copenhagen, v. 32, n.4, p. 406-11, Apr. 2005.

ÇETIN, E. O.; BUDUNELI, N.; ATLIHAN, E.; KIRILMAZ, L. In vitro studies on controlled-release cellulose acetate films for local delivery of chlorhexidine, indomethacin, and meloxicam. Journal of Clinical Periodontology, Copenhagen, v. 31, n. 12, p. 1117-1121, Dec. 2004.

CHAMPAGNE, C. M.; BUCHANAN, W.; REDDY, M. S.; PREISSER, J. S.; BECK, J. D.; OFFENBACHER, S. Potential for gingival crevice fluid measures as predictors of risk for periodontal diseases. Periodontology 2000, Copenhagen, v.31, n.1, p.16780, 2003.

CIONCA N, GIANNOPOULOU C, UGOLOTTI G, MOMBELLI A. Amoxicillin and metronidazole as an adjunct to full-mouth scaling and root planing of chronic periodontitis. Journal of Periodontology, Chicago, v.80, n.3, p.364-71, Mar. 2009.

CHAPPLE, I. L. C.; LANDINI, G.; GRIFFITHS, G. S.; PATEL, N. C.; WARD, R. S. N. Calibration of the Periotron 8000 and 6000 by polynomial regression. Journal of Periodontal Research, Copenhagen, v. 34, n. 2, p. 79-86, Feb. 1999.

CIONCA, N.; GIANNOPOULOU, C.; UGOLOTTI, G.; MOMBELLI „A. Amoxicillin and metronidazole as an adjunct to full-mouth scaling and root planing of chronic periodontitis Journal of Periodontology, Chicago, v.80, n.3, p.364-71, Mar. 2009.

CLARK, D. C.; SHENKER, S.; STULGINSKI, P.; CHWARTZ, S. Effectiveness of routine periodontal treatment with and without adjunctive metronidazole therapy in samples of mentally retarded adolescents. Journal of Periodontology, Chicago, v. 54 , p. 658-665,1983.

COLOMBO AV, SILVA CM, HAFFAJEE A, COLOMBO APV. Identification of oral bacteria associated with crevicular epithelial cells from chronic periodontitis lesions. Journal of Medical Microbiology, Edinburgh, v.55, (Pt 5), p.609-615, May. 2006.

COLOMBO, A. P.; BOCHES, S. K.; COTTON, S. L.; GOODSON, J. M.; KENT, R.; HAFFAJEE, A. D.; SOCRANSKY, S. S.; HASTURK, H.; VAN DYKE, T. E, DEWHIRST, F.; PASTER, B. J. Comparisons of subgingival microbial profiles of refractory periodontitis, severe periodontitis, and periodontal health using the human 
oral microbe identification microarray. Journal of Periodontology, Chicago , v. 80, n.9, p. 1421-32, Sep. 2009.

CUGINI, M. A.; HAFFAJEE, A. D.; SMITH, C.; KENT JÚNIOR, R. L.; SOCRANSKY, S. S. The effect of scaling and root planing on the clinical and microbiological parameters of periodontal diseases: 12-month results. Journal of Clinical Periodontology, Copenhagen, v. 27, n.1, p.30-36, Jan. 2000.

DAHAN, M.; NAWROCKI, B.; ELKAÏM, R.; SOELL, M.; BOLCATO-BELLEMIN, A. L.; BIREMBAUT, P.; TENENBAUM, H. Expression of matrix metalloproteinases in healthy and diseased human gingiva. Journal of Clinical Periodontology, Copenhagen, v.28, n.2, p.128-36, Feb. 2001.

DANNEWITZ, B.; POHL, S.; EICKHOLZ, P.; KIM, T. S. Clinical and microbiological effects of a combined mechanic-antibiotic therapy in subjects with Actinobacillus actinomycetemcomitans-associated periodontitis. American Journal of Dentistry, San Antonio, v.20, n.3, p.153-6, Jun. 2007.

DEINZER, R.; MOSSANEN, B. S.; HERFORTH, A. Methodological considerations in the assessment of gingival crevicular fluid volume. Journal of Clinical Periodontology, Copenhagen, v. 27, n. 7, p. 481-488, Jul. 2000.

DO NASCIMENTO, C.; MONESI, N.; DA SILVA, J. A.; DE ALBUQUERQUE, R. F. JUNIOR. An alternative method for direct DNA probe labeling and detection on checkerboard hybridization format. Journal of Clinical Microbiology, Washington, Jun. 2010. In Press.

DUERDEN, B. I. The isolation and identification of Bacteroides spp. from the normal human gingival flora. Journal of Medical Microbiology, Edinburgh, v.13, n.1, p.89101, Feb. 1980.

DUMORTIER, G.; GROSSIORD, J. L.; AGNELY, F.; CHAUMEIL, J. C. A review of poloxamer 407 pharmaceutical and pharmacological characteristics. Pharmaceutical Research., Stuttgart, v.23, n.12, p.2709-28, Dec. 2006.

EDWARDSSON, S.; BING, M.; AXTELIUS, B.; LINDBERG, B.; SÖDERFELDT, B.; ATTSTRÖM, R. The microbiota of periodontal pockets with different depths in therapy-resistant periodontitis. Journal of Clinical Periodontology, Copenhagen, v.26, n.3, p. 143-152. Mar. 1999.

EHMKE, B.; MOTER, A.; BEIKLER, T.; MILIAN, E.; FLEMMIG, T. F. Adjunctive antimicrobial therapy of periodontitis: long-term effects on disease progression and oral colonization. Journal of Periodontology, Chicago, v.76, n.5, p.749-59, May. 2005. 
ESPOSITO, E.; CAROTTA, V.; SCABBIA, A.; TROMBELLI, L.; D'ANTONA, P.; MENEGATTI, E.; NASTRUZZI, C. Comparative analysis of tetracycline-containing dental gels: poloxamer- and monoglyceride-based formulations. International Journal of Pharmaceutics, Amsterdam, v. 142, n. 1, p. 9-23, Sep. 1996.

FAVERI, M.; FERES, M, GURSKY, L. C.; MARTINS, V. N, CAIXETA NETO, L. S FIGUEIREDO, L. C. Controle da placa bacteriana supragengival na terapia periodontal não-cirúrgica. Revista de Odontologia da UNESP, Araraquara, v. 35, n.4, p.313-18, 2006.

FERES, M.; HAFFAJEE, A.D.; ALLARD, K.; SOM, S.; SOCRANSKY, S. S. Change in subgingival microbial profiles in adult periodontitis subjects receiving either systemically administered amoxicillin or metronidazole. Journal of Clinical Periodontology, Copenhagen, v.28, n.7, p.597-609, Jul. 2001.

GABARRA, F. R. Dispositivo mimetizador de bolsa periodontal para estudos de liberação de fármaco. 2002. 199 f. Tese (Doutorado em Reabilitação Oral) Faculdade de Odontologia de Ribeirão Preto, Universidade de São Paulo, Ribeirão Preto, 2002.

GIBBS, C. H.; HIRSCHFELD, J. W.; LEE, J. G.; LOW, S. B.; MAGNUSSON, I.; THOUSAND, R. R.; YERNENI, P.; CLARK, W. B. Description and clinical evaluation of a new computerized periodontal probe--the Florida probe. Journal of Clinical Periodontology, Copenhagen, v.15, n.2, p.137-44, Feb. 1988.

GOENÉ, R. J.; WINKEL, E. G.; ABBAS, F.; RODENBERG, J. P.; VAN WINKELHOFF ,A. J.; DE GRAAFF, J. Microbiology in diagnosis and treatment of severe periodontitis. A report of four cases. Journal of Periodontology, Chicago, v.61, n.1, p. 61-64, Jan. 1990.

GOLOMB, G.; FRIEDMAN, M.; SOSKOLNE, A.; STABHOLZ, A.; SELA, M. N. Sustained release device containing metronidazole for periodontal use. Journal of Dental Research, Chicago, v. 63, n. 9, p. 1149-1153, Sep. 1984.

GOMES, S. C.; PICCININ, F. B.; OPPERMANN, R. V.; SUSIN, C.; NONNENMACHER, C. I.; MUTTERS, R.; MARCANTONIO, R. A. Periodontal status in smokers and never-smokers: clinical findings and real-time polymerase chain reaction quantification of putative periodontal pathogens. Journal of Periodontology, Chicago, v.77, n. 9, p. 1483-90, Sep. 2006.

GOPINATH, V.; RAMAKRISHNAN, T.; EMMADI, P.; AMBALAVANAN, N. MAMMEN, $B$.; VIJAYALAKSHMI. Effect of a controlled release device containing minocycline microspheres on the treatment of chronic periodontitis: A comparative study. Journal of Indian Society of Periodontology, Mumbai, v.13, n.2, p.79-84, May. 2009. 
GOODSON, J. M.; HAFFAJEE, A.; SOCRANSKY, S. S. Periodontal therapy by local delivery of tetracycline. Journal of Clinical Periodontology, Copenhagen, v. 6, n. 2, p. 83-92, Apr. 1979.

GOODSON, J. M.; HOLBOROW, D.; DUNN, R. L.; HOGAN, P.; DUNHAM, S. Monolithic tetracycline-containing fibers for controlled delivery to periodontal pockets. Journal of Periodontology, Copenhagen, v. 54, n. 10, p. 575-579, Oct. 1983.

GOODSON, J. M. Pharmacokinetic principles controlling efficacy of oral therapy. Journal of Dental Research, Chicago, v. 68, Special issue, p. 1625-1632, 1989.

GOODSON, J. M. Antimicrobial strategies for treatment of periodontal diseases. Periodontology 2000, Copenhagen, v. 5, p.142-168, Jun. 1994.

GOODSON, J. M. Gingival crevice fluid flow. Periodontology 2000, Copenhagen, v. 31, p. 43-54, 2003.

GORDON, J.M.; WALKER, C. B.; GOODSON, J. M.; SOCRANSKY, S. S. Sensitive assay for measuring tetracycline levels in gingival crevice fluid. Antimicrobial Agents and Chemotherapy, Washington, v.17, n. 2, p. 193-198, Feb. 1980.

GORDON, M.J.; WALKER, B. C. Current status of systemic antibiotic usage in destructive periodontal desease. Journal of Periodontology, Chicago, v.64 (Supll 8), p.760-771, Aug. 1993.

GRACA, M. A.; WATTS, T. L.; WILSON, R. F.; PALMER, R. M. A randomized controlled trial of a $2 \%$ minocycline gel as an adjunct to non-surgical periodontal treatment, using a design with multiple matching criteria. Journal of Clinical Periodontology, Copenhagen, v. 24, n. 4, p. 249-253, Apr. 1997.

GREENSTEIN, G., D. D. S; M. S. Nonsurgical periodontal therapy in 2000: a literature review. Journal of the American Dental Association, Chicago, v. 131, n.11, p.1580-92, Nov. 2000.

GRIFFITHS, G. S.; SMART, G. J.; BULMAN, J. S.; WEISS, G.; SHROWDER, J.; NEWMAN, H. N. Comparison of clinical outcomes following treatment of chronic adult periodontitis with subgingival scaling or subgingival scaling plus metronidazole gel. Journal of Clinical Periodontology, Copenhagen v. 27, n. 12, p. 910-917, Dec. 2000.

HAAKE, S. K.; NISENGARD, R. J.; NEWMAN, M. G.; MIYASAKI, K. T. Interações microbianas com o hospedeiro nas doenças periodontais. In: Carranza, F. A.; 
Newman, M. G.; Takei, H. H. Periodontia clínica. 9. ed. Rio de Janeiro: Guanabara Koogan, cap 8, p. 118-136. 2004.

HAFFAJEE, A. D.; CUGINI, M. A.; DIBART, S.; SMITH, C.; KENT JÚNIOR, R. L.; SOCRANSKY, S. S. The effect of SRP on the clinical and microbiological parameters of periodontal diseases. Journal of Clinical Periodontology, Copenhagen, v.24, n. 5p. 324-34, May. 1997.

HAFFAJEE, A. D.; UZEL, N.G.; ARGUELLO, E. I.; TORRESYAP, G. GUERRERO, D. M.; SOCRANSKY, S. S .Clinical and microbiological changes associated with the use of combined antimicrobial therapies to treat "refractory" periodontitis. Journal of Clinical Periodontology, Copenhagen, v.31, n.10, p. 869-77, Oct. 2004.

HAFFAJEE, A. D.; TELES, R. P.; SOCRANSKY, S. S. The effect of periodontal therapy on the composition of the subgingival microbiota. Periodontology 2000, Copenhagen, v.42, p.219-58, 2006.

HAFFAJEE, A. D.; PATEL, M., SOCRANSKY, S. S. Microbiological changes associated with four different periodontal therapies for the treatment of chronic periodontitis. Oral microbiology and immunology, Copenhagen, v. 23, n.2, p. 14857, Apr. 2008.

HERRERA, D.; SANZ, M.; JEPSEN, S.; NEEDLEMAN, I.; ROLDÁN, S. A systematic review on the effect of systemic antimicrobials as an adjunct to scaling and root planing in periodontitis patients. Journal of Clinical Periodontology, Copenhagen, v. 29, Suppl 3, p.136-59; discussion 160-2, 2002.

HINTZE, J. NCSS, PASS and GESS. Kaysville: NCSS, 2006. Available in: www.ncss.com.

HITZIG, C.; CHARBIT, Y.; BITTON, C.; FOSSE, T.; TEBOUL, M.; HANNOUN, L.; VARONNE, R. Topical metronidazole as an adjunct to subgingival debridement in the treatment of chronic periodontitis. Journal of Clinical Periodontology, Copenhagen, v.21, n.2, p.146-57, Feb. 1994.

HITZIG, C.; FOSSE ,T.; CHARBIT, Y.; BITTON, C.; HANNOUN, L. Effects of combined topical metronidazole and mechanical treatment on the subgingival flora in deep periodontal pockets in cuspids and bicuspids. Journal of Periodontology, Chicago, v.68, n.7, p.613-7, Jul. 1997.

JANATOVÁ, T.; NAJMANOVÁ, L.; NEUBAUEROVÁ, L.; KYSELKOVÁ, M.; NOVOTNÁ, G.; SPÍZEK, J.; JANATA, J.; DUSKOVÁ, J. Changes in the incidence of periodontal pathogens during long-term monitoring and after application of antibacterial drugs. Folia microbiológica, Praha, v.54, n.5, p.429-35, Sep. 2009. 
JANSSON, H.; BRATTHALL, G.; SODERHOLM, G. Clinical outcome observed in subjects with recurrent periodontal disease following local treatment with $25 \%$ metronidazole gel. . Journal of Periodontology, Chicago, v. 74, n. 3, p. 372-377, Mar. 2003.

JANSSON, H.; HAMBERG, K.; SODERHOLM, G.; BRATTHALL, G. The microbial outcome observed with polymerase chain reaction in subjects with recurrent periodontal disease following local treatment with $25 \%$ metronidazole gel. Swedish Dental Journal, Jönköping, v. 28, n. 2, p. 67-76, 2004.

JOHNSON, J. D.; CHEN, R.; LENTON, P. A; ZHANG, G.; HINRICHS, J. E.; RUDNEY, J. D. Persistence of extracrevicular bacterial reservoirs after treatment of aggressive periodontitis. Journal of Periodontology, Chicago, v. 79, n.12, p.230512, Dec. 2008.

JONES, D. S.; WOOLFSON, D.; BROWN, A. F.; O'NEILL, M. J. Mucoadhesive, syringeable drug delivery systems for controlled application of metronidazole to the periodontal pocket: In vitro release kinetics, syringeability, mechanical and mucoadhesive properties. Journal of Controlled Release, Amsterdam, v. 49, n. 1, p. 71-79, Nov. 1997.

JOUSIMIES-SOMER, H.; ASIKAINEN, S.; SUOMALA, P.; SUMMANEN, P. Activity of metronidazole and its hydroxy metabolite against clinical isolates of Actinobacillus actinomycetemcomitans. Oral Microbiology and Immunology, Copenhagen, v.3, n.1, p.32-34, Mar. 1988.

KALDAHL, W. B.; KALKWARF, K. L.; PATIL, K. D.; DYER, J. K.; BATES, R. E. JR. Evaluation of four modalities of periodontal therapy. Mean probing depth, probing attachment level and recession changes. Journal of Periodontology, Chicago, v.59, n.12, p.783-93, Dec.1988.

KALDAHL, W. B.; KALKWARF, K. L.; PATIL, K. D.; MOLVAR, M. P.; DYER, J. K. Long-term evaluation of periodontal therapy: I. Response to 4 therapeutic modalities. Journal of Periodontology, Chicago, v.67, n.2, p.93-102, Feb. 1996.

KELLY, H. M.; DEASY, P. B.; ZIAKA, E.; CLAFFEY, N. Formulation and preliminary in vivo dog studies of a novel drug delivery system for the treatment of periodontitis. International Journal of Pharmaceutics, Amsterdam, v. 274, n. 1-2, p. 167-183, Apr. 2004.

KHOSRAVI, M.; BAHRAMI, Z. S.; ATABAKI, M. S.; SHOKRGOZAR, M. A.; SHOKRI, $F$. Comparative effectiveness of hand and ultrasonic instrumentations in root surface planing in vitro. Journal of Clinical Periodontology, Copenhagen, v. 31, n.3, p.1605, Mar. 2004. 
KIM, T. S.; KLIMPEL, H.; FIEHN, W.; EICKHOLZ, P. Comparison of the pharmacokinetic profiles of two locally administered doxycycline gels in crevicular fluid and saliva. Journal of Clinical Periodontology, Copenhagen, v. 31, n. 4, p. 286-292, Apr. 2004.

KINANE, D. F.; RADVAR, M. A six-month comparison of three periodontal local antimicrobial therapies in persistent periodontal pockets. Journal of Periodontology, Chicago, v. 70, n. 1, p. 1-7, Jan. 1999.

KLINGE, B.; ATTSTROM, R.; KARRING, T.; KISCH, J.; LEWIN, B.; STOLTZE, K. 3 regimens of topical metronidazole compared with subgingival scaling on periodontal pathology in adults. Journal of Clinical Periodontology, Copenhagen ,v. 19, n. $9 \mathrm{Pt}$ 2, p. 708-714, Oct. 1992.

LANG, N. P.; SCHÄTZLE, M. A., LÖE, H. Gingivitis as a risk factor in periodontal disease. Journal of Clinical Periodontology, Copenhagen, v. 36, n. 10 Suppl , p. 38, Jul. 2009.

LEIKNES, T.; LEKNES, K. N.; BÖE, O. E.; SKAVLAND, R. J.; LIE, T. Topical use of a metronidazole gel in the treatment of sites with symptoms of recurring chronic inflammation. Journal of Periodontology, Chicago, v.78, n.8, p. 1538-44, Aug. 2007.

LEKOVIC, V.; KENNEY, E. B.; CARRANZA, F. A. JR.; ENDRES, B. The effect of metronidazole on human periodontal disease. A clinical and bacteriological study., $\mathrm{v}$. 54, n.8, Journal of Periodontology, Chicago p. 476-80, Aug. 1983.

LEVIN-GOLDSTEIN, D. The local drug delivery of tetracycline, metronidazole, and chlorhexidine in periodontal therapy. Journal of Dental Hygiene, Chicago, v.66, n.9, p. 410-6, Nov. 1996.

LIE, T.; BRUUN, G. BÖE, O. E. Effects of topical metronidazole and tetracycline in treatment of adult periodontitis. Journal of Periodontology, Chicago, v. 69, n. 7, p. 819-827, Jul. 1998.

LINDHE, Jan. Tratado de Periodontia Clínica e Implantologia Oral. 4 a edição. Guanabara Koogan, 2005.

LÖE, H.; THEILADE, E.; JENSEN, S. B. Experimental gingivitis in man. Journal of Periodontology, Chicago , v. 36, n.1, p. 77-87, May-Jun. 1965.

LÖE, $H$. The role of bacteria in periodotopathies. Bulletin of the World Health Organization, Geneva, v. 60, n. 2, p.179-83, 1982. 
LÖE, H.; ANERUD, A.; BOYSEN, H.; MORRISON, E. Natural history of periodontal disease in man. Rapid, moderate and no loss attachment in Sri Lankan laborers 14 to 46 years of age. Journal of Clinical Periodontology, Copenhagen, v.13, n.5, p. 431-45, May. 1986.

LOESCHE, W. J.; SCHMIDT, E.; SMITH, A.; MORRISON, E. C.; CAFFESSE, R.; HUJOEL, P. P. Effects of metronidazole on periodontal treatment needs. Journal of Periodontology, Chicago, v.62, n.4, p.247-257, Apr. 1991.

LOESCHE, W. J.; GROSSMANM, N.; GIORDANO, J. Metronidazole in periodontitis (IV) The effect of patient compliance on treatment parameters. Journal of Clinical Periodontology, Copenhagen, v.20, n.2, p. 96-104, Feb.1993.

LOESCHE, W. J.; GIORDANO, J. R. Metronidazole in periodontitis V: debridement should precede medication. Compendium. Newtown, v. 15, n.10, p.1198, 1201, 1203 passim; quiz 1218, Oct. 1994.

LÖFMARK, S.; EDLUND, C.; NORD, C. E. Metronidazole is still the drug of choice for treatment of anaerobic infections. Clinical Infectious Diseases, Chicago, v.50, Suppl 1:S16-23, Jan, 2010.

LÓPEZ, N. J.; SOCRANSKY, S. S.; SILVA, I.; JAPLLIT, M. R.; HAFFAJEE, A. D. Effects of metronidazole plus amoxicilin as the only therapy on the microbiological and clinical parameters of untreated chronic periodontitis. Journal of Clinical Periodontology, Copenhagen, v.33, n.9, p. 648-60, Sep. 2006.

LOVDAL, A.; ARNO, A.; WAERHAUGH, J. Incidence of clinical manifestations of periodontal disease in light of oral higiene and calculus formation, Journal of the American Dental Association, Chicago, v. 56, n.1, p.21-33, Jan. 1958.

MACHTEI, E. E.; CHRISTERSSON, L. A.; GROSSI, S. G.; DUNFORD, R.; ZAMBON, J. J.; GENCO, R. J. Clinical criteria for the definition of "established periodontitis". Journal of Periodontology, Chicago, v. 63, n. 3, p. 206-214, Mar. 1992.

MAGNUSSON, I.; LINDHE, J.; YONEYAMA, T.; LILJENBERG, B. Recolonization of a subgingival microbiota following scaling in deep pockets. Journal of Clinical Periodontology, Copenhagen, v.11, n.3, p.193-207, Mar. 1984.

MAGNUSSON I. Computerized periodontal probing. Periodontology 2000, Copenhagen, v.12, p.40-3. Oct. 1996. 
MAGNUSSON, I. The use of locally delivered metronidazole in the treatment of periodontitis. Clinical results. Journal of Clinical Periodontology, Copenhagen, v. 25, n. 11(Pt. 2), p. 959-963, Nov. 1998.

MCCULLOCH, C. A. Collagenolytic enzymes in gingival crevicular fluid as diagnostic indicators of periodontitis. Annals of the New York Academy of Sciences, New York, v. 732, n., p. 152-164, Sep 6. 1994.

MESTNIK, M. J.; FERES, M.; FIGUEIREDO, L. C.; DUARTE, P. M.; LIRA, E. A.; FAVERI, M. Short-term benefits of the adjunctive use of metronidazole plus amoxicillin in the microbial profile and in the clinical parameters of subjects with generalized aggressive periodontitis. Journal of Clinical Periodontology, Copenhagen, v.37, n.4, p.353-65, Apr. 2010.

MILLER, C. S.; KING, C. P., JR.; LANGUB, M. C.; KRYSCIO, R. J.; THOMAS, M. V. Salivary biomarkers of existing periodontal disease: a cross-sectional study. Journal of the American Dental Association, Chicago, v. 137, n. 3, p. 322-329, Mar. 2006.

MÜLLER, H. P.; LANGE, D. E.; MÜLLER, R. F. Actinobacillus actinomycetemcomitans recovery from extracrevicular locations of the mouth. Oral Microbiology and Immunology, Copenhagen, v.8, n.6, p. 344-8, Dec.1993.

MÜLLER, H. P.; HEINECKE, A.; BORNEFF, M.; KIENCKE, C.; KNOPF, A.; POHL, S. Eradication of Actinobacillus actinomycetemcomitans from the oral cavity in adult periodontitis. Journal of Periodontal Research, Copenhagen, v. 33, n.1, p.49-58, 1998.

MOMBELLI, A.; SCHMID, B.; RUTAR, A.; LANG, N. P. Persistence patterns of Porphyromonas gingivalis, Prevotella intermedia/nigrescens, and Actinobacillus actinomycetemcomitans after mechanical therapy of periodontal disease. Journal of Periodontology, Chicago, v. 71, p.14-21, Jan. 2000.

MOMBELLI, A.; GMUR, R.; GOBBI, C.; LANG, N. P. Actinobacillus actinomycetemcomitans in adult periodontitis. Characterization of isolated strains and effect of mechanical periodontal treatment. Journal of Periodontology, Chicago, v.64, p. 827-834, Sep. 1994

MOMBELLI, A.; SAMARANAYAKE L. P. Topical and systemic antibiotics in the management of periodontal diseases. International Dental Journal, London, v. 54, n.1, p.3-14, Feb. 2004.

MONCRIEF, J. S.; OBISO, R. JR.; BARROSO, L. A.; KLING, J. J.; WRIGHT, R. L.; VAN TASSELL, R. L.; LYERLY, D. M.; WILKINS, T. D. The enterotoxin of 
Bacteroides fragilis is a metalloprotease. Infection and Immunity, Bethesda, v.63, n.1, p.175-81, Jan. 1995.

MOORE, W. E.; MOORE, L. V. The bacteria of periodontal diseases. Periodontology 2000, Copenhagen, v. 5, p. 66-77, Jun. 1994.

MORRISON, E. C.; RAMFJORD, S. P.; HILL, R. W. Short-term effects of initial, nonsurgical periodontal treatment (hygienic phase). Journal of Clinical Periodontology, Copenhagen, v. 7, n.3, p.199-211, Jun. 1980.

MÜLLER, H. P.; LANGE, D. E.; MÜLLER, R. F. Actinobacillus actinomycetemcomitans recovery from extracrevicular locations of the mouth. Microbiology and Immunology, Copenhagen, v.8, n.6, p. 344-348, Dec.1993.

NAKAGAWA, T.; YAMADA, S.; OOSUKA, Y.; SAITO, A.; HOSAKA, Y.; ISHIKAWA, T.; OKUDA, K. Clinical and microbiological study of local minocycline delivery (Periocline) following scaling and root planing in recurrent periodontal pockets. The Bulletin of Tokyo Dental College, Tokyo, v. 32, n. 2, p. 63-70, May. 1991.

NASCIMENTO, C. Avaliação da infiltração bacteriana através da interface implante-conector protético sob aplicação de carga - avaliação in vitro pelo método DNA Checkerboard. 2010. 200 f. Tese (Doutorado) - Faculdade de Odontologia de Ribeirão Preto, Universidade de São Paulo, Ribeirão Preto, 2010.

NEEDLEMAN, I. G.; WATTS, T. L. The effect of $1 \%$ metronidazole gel in routine maintenance of persistent furcation involvement in human beings. Journal of Periodontology, Chicago, v. 60, n. 12, p. 699-703, Dec. 1989.

NG VW, BISSADA NF. Clinical evaluation of systemic doxycycline and ibuprofen administration as an adjunctive treatment for adult periodontitis. Journal of Periodontology, Chicago, v.69, n.7, p.772-6, Jul. 1998.

NEWMAN, H. N.; YEUNG, F. I.; WAN YUSOF, W. Z.; ADDY, M. Slow release metronidazole and a simplified mechanical oral hygiene regimen in the control of chronic periodontitis. Journal of Clinical Periodontology, Copenhagen, v. 11, n. 9, p. 576-582, Oct. 1984.

NIEDERMAN, R. Manual and electronic probes have similar reliability in the measurement of untreated periodontitis. Evidence-based Dentistry, London, v.10, n.2, p.39, 2009.

NOIRI, Y., OKAMI, Y., NARIMATSU, M., TAKAHASHI, Y., KAWAHARA, T.; EBISU, $S$. Effects of chlorhexidine, minocycline, and metronidazole on Porphyromonas 
gingivalis strain 381 in biofilms. Journal of Periodontology, Chicago, v. 74, n. 11, 1647-1651, Nov. 2003.

NORLING, T.; LADING, P.; ENGSTROM, S.; LARSSON, K.; KROG, N.; NISSEN, S. $\mathrm{S}$. Formulation of a drug delivery system based on a mixture of monoglycerides and triglycerides for use in the treatment of periodontal disease. Journal of Clinical Periodontology, Copenhagen, v. 19, n. 9 Pt 2, p. 687-692, Oct. 1992.

NOTTEN, F.; KOEK-VAN OOSTEN, A.; MIKX, F. Capillary agar diffusion assay for measuring metronidazole in human gingival crevice fluid. Antimicrobial Agents and Chemotherapy, Washington, v. 21, n.5, p. 836-837, May. 1982.

PAAVOLA, A.; YLIRUUSI, J.; ROSENBERG, P. Controlled release and dura mater permeability of lidocaine and ibuprofen from injectable poloxamer-based gels. Journal of Controlled Release, Amsterdam, v. 52, n. 1-2, p. 169-478, Mar. 1998.

PAGE, R. C.; DEROUEN, T. A. Design issues specific to studies of periodontitis. Journal of Periodontal Research, Copenhagen, v. 27, n. 4 Pt 2, p. 395-404; discussion 412-396, Jul. 1992.

PAGE, R. C. The pathobiology of periodontal diseases may affect systemic diseases: inversion of paradigm. Annals of Journal of Periodontology, Chicago, v. 3, n.1, p.108-20, Jul.1998.

PÄHKLA, E. R.; KOPPEL, T.; SAAG, M.; PAHKLA, R. Metronidazole concentrations in plasma, saliva and periodontal pockets in patients with periodontitis. Journal of Clinical Periodontology, Copenhagen, v.32, n.2, p.163-6, Feb. 2005.

PALMER, R. M.; MATTHEWS, J. P.; WILSON, R. F. Adjunctive systemic and locally delivered metronidazole in the treatment of periodontitis: a controlled clinical study. British Dental Journal, London, v. 184, n. 11, p. 548-552, Jun 13. 1998.

PAOLANTONIO, M.; D'ERCOLE, S.; PILLONI, A.; D'ARCHIVIO, D.; LISANTI, L.; GRAZIANI, F.; FEMMINELLA, ; SAMMARTINO, G.; PERILLO, L.; TETĖ, S.; PERFETTI, G.; SPOTO, G.; PICCOLOMINI, R.; PERINETTI, G. Clinical, microbiologic, and biochemical effects of subgingival administration of a xanthanbased chlorhexidine gel in the treatment of periodontitis: a randomized multicenter trial. Journal of Periodontology, Chicago, v. 80, n.9, p.1479-92, Sep. 2009.

PAQUETTE, D.; ORINGER, R.; LESSEM, J.; OFFENBACHER, S.; GENCO, R.; PERSSON, G.R.; SANTUCCI, E.A.; WILLIAMS, R.C: Locally delivered minocycline microspheres for the treatment of periodontitis in smokers. Journal of Clinical Periodontology, Copenhagen, v. 30, n. 9, p. 787-794, Sep. 2003. 
PASTER, B. J.; BOCHES, S. K.; GALVIN, J. L.; ERICSON, R. E.; LAU, C. N.; LEVANOS, V. A.; SAHASRABUDHE, A.; DEWHIRST, F. E. Bacterial diversity in human subgingival plaque. Journal of Bacteriology, Baltimore, v. 183, n.12, p. 3770-83, Jun. 2001.

PEDRAZZI, V. Sistemas bioadesivos intra-bucais para a liberação programada de fármacos: avaliação da resistência à remoção de um dispositivo acrílico e outro polimérico. 1999. 169 f. Tese (Doutorado em Reabilitação Oral) - Faculdade de Odontologia de Ribeirão Preto, Universidade de São Paulo, Ribeirão Preto, 1999.

PEDRAZZOLI, V.; KILIAN, M.; KARRING, T. Comparative clinical and microbiological effects of topical subgingival application of metronidazole $25 \%$ dental gel and scaling in the treatment of adult periodontitis. Journal of Clinical Periodontology, v. 19, n. 9 Pt 2, p. 715-722, Oct. 1992.

PERINETTI, G.; PAOLANTONIO, M.; CORDELLA, C.; D'ERCOLE, S.; SERRA, E.; PICCOLOMINI, R. Clinical and microbiological effects of subgingival administration of two active gels on persistent pockets of chronic periodontitis patients. Journal of Clinical Periodontology, Copenhagen, v. 31, n. 4, p. 273-281, Apr. 2004.

PERIOLI, L.; AMBROGI, V.; RUBINI, D.; GIOVAGNOLI, S.; RICCI, M. BLASI, P.; ROSSI, C. Novel mucoadhesive buccal formulation containing metronidazole for the treatment of periodontal disease. Journal of Controlled Release, Amsterdam, v.95, n.3, p.521-33, Mar. 2004.

PETERSILKA GJ, EHMKE B, FLEMMIG TF Antimicrobial effects of mechanical debridement. Periodontology 2000, Copenhagen, v. 28, p. 56-71, 2002.

PREUS, H. R.; LASSEN, J.; AASS, A. M.; CIANCIO, S. G. Bacterial resistance following subgingival and systemic administration of minocycline. Journal of Clinical Periodontology, Copenhagen, v.22, n.5, p.380-4. May.1995.

PIHLSTROM, B. Issues in the evaluation of clinical trials of periodontitis: a clinical perspective. Journal of Periodontal Research, Copenhagen, v. 27, n. $4 \mathrm{Pt} 2$, p. 433-441, Jul. 1992.

POLSON, A. M.; GARRETT, S.; STOLLER, N. H.; BANDT, C. L.; HANES, P. J.; KILLOY, W. J.; SOUTHARD, G. L.; DUKE, S. P.; BOGLE, G. C.; DRISKO, C. H.; FRIESEN, L. R. Multi-center comparative evaluation of subgingivally delivered sanguinarine and doxycycline in the treatment of periodontitis. II. Clinical results. Journal of Periodontology, Chicago, v. 68, n. 2, p. 119-126, Feb. 1997.

POURTAGHI, N.; RADVAR, M.; MOONEY, J.; KINANE, D. F. The effect of subgingival antimicrobial therapy on the levels of stromelysin and tissue inhibitor of 
metalloproteinases in gingival crevicular fluid. Journal of Periodontology, Chicago, v.67, n.9, p.866-70, Sep.1996.

QUIRYNEN, M.; MONGARDINI, C.; PAUWELS, M.; BOLLEN, C. M.; VAN ELDERE, J.; VAN STEENBERGHE, D. One stage full- versus partial-mouth disinfection in the treatment of chronic adult or generalized early-onset periodontitis. II. Long-term impact on microbial load. Journal of Periodontology, Chicago, v.70, n.6, p.646-56, Jun. 1999.

QUIRYNEN, M.; PAPAIOANNOU, W.; VAN STEENBERGEN, T. J.; DIERICKX, K.; CASSIMAN, J. J.; VAN STEENBERGHE, D. Adhesion of Porphyromonas gingivalis strains to cultured epithelial cells from patients with a history of chronic adult periodontitis or from patients less susceptible to periodontitis. Journal of Periodontology, Chicago, v.71, n.5, p.626-33, May. 2001.

QUIRYNEN, M.; De SOETE, M.; Van STEENBERGHE, D. Infectious risks for oral implants: a review of the literature. Clinical Oral Implants Research, Copenhagen, v.13, n. 1, p.1-19, Feb. 2002.

RAMBERG, P.; ROSLING, B.; SERINO, G.; HELLSTRÖM, M. K.; SOCRANSKY, S. S.; LINDHE, J. The long-term effect of systemic tetracycline used as an adjunct to non-surgical treatment of advanced periodontitis. Journal of Clinical Periodontology, Copenhagen, v.28, n.5, p.446-52, May. 2001.

RAMS, T. E.; BABALOLA, O. O.; SLOTS, J. Subgingival occurrence of enteric rods, yeasts and staphylococci after systemic doxycycline therapy. Oral Microbiology and Immunology, Copenhagen, v.5, n.3, p.166-8, Jun. 1990.

RENVERT, S.; DAHLEN, G.; WIKSTRÖM, M. The clinical and microbiological effects of non-surgical periodontal therapy in smokers and non-smokers. Journal of Clinical Periodontology, Copenhagen, v. 25, n. 2, p. 153-157, 1998.

RENVERT, S.; LESSEM, J.; DAHLEN, G.; LINDAHL, C.; SVENSSON, M. Topical minocycline microspheres versus topical chlorhexidine gel as an adjunct to mechanical debridement of incipient peri-implant infections: a randomized clinical trial. Journal of Clinical Periodontology, Copenhagen, v. 33, n. 5, p. 362-369, May. 2006.

RESCALA, B.; ROSALEM, W.; TELES, R. P.; FISCHER, R. G.; HAFFAJEE, A.; SOCRANSKY, S.; GUSTAFSSON, A.; FIGUEREDO, C. Immunological and Microbiological Profiles of Chronic and Aggressive Periodontitis Subjects. Journal of Periodontology, Chicago, May 7, 2010. In Press. 
RIEP, B.; PURUCKER, P.; BERNIMOULIN, J. P. Repeated local metronidazoletherapy as adjunct to scaling and root planing in maintenance patients. Journal of Clinical Periodontology, Copenhagen, v. 26, n. 11, p. 710-715, Nov. 1999.

RIBEIRO EDEL, P.; BITTENCOURT, S.; ZANIN, I. C.; BOVI AMBROSANO, G. M.; SALLUM, E. A.; NOCITI, F. H.; GONÇALVES, R. B.; CASATI, M. Z. Full-mouth ultrasonic debridement associated with amoxicillin and metronidazole in the treatment of severe chronic periodontitis. Journal of Periodontology, Chicago, v.80, n.8, p.1254-64, Aug. 2009.

RIZZO, A.; PAOLILLO, R.; GUIDA, L.; ANNUNZIATA, M.; BEVILACQUA, N.; TUFANO, M. A. Effect of metronidazole and modulation of cytokine production on human periodontal ligament cells. International Immunopharmacology, Amsterdam, Apr, 22. 2010. In press.

ROONEY, J.; WADE, W. G.; SPRAGUE, S. W.; NEWCOMBE, R. G.; ADDY, M. Adjunctive effects to non-surgical periodontal therapy of systemic metronidazole and amoxycillin alone and combined. A placebo controlled study. Journal of Clinical Periodontology, Copenhagen, v.29, n.4, p.342-50, Apr. 2002.

RUDHART, A.; PURUCKER, P.; KAGE, A., HOPFENMÜLLER, W.; BERNIMOULIN, J. P. Local metronidazole application in maintenance patients. Clinical and microbiological evaluation. Journal of Periodontology, Chicago, v.69, n.10, p.114854, Oct. 1998.

RUDNEY, J. D.; CHEN, R.; SEDGEWICK, G. J. Actinobacillus actinomycetemcomitans, Porphyromonas gingivalis, and Tannerella forsythensis are components of a polymicrobial intracellular flora within human buccal cells. Journal of Dental Research, Chicago, v.84, n.1, p.59-63, Jan. 2005.

RUSSEL, A. L. Epidemiology of periodontal disease. A review of the literature. International Dental Journal, London, v.17, n. 2, p. 282-96. Jun. 1967.

SALVI, G. E.; MOMBELLI, A.; MAYFIELD, L.; RUTAR, A.; SUVAN, J.; GARRETT, S.; LANG, N. P. Local antimicrobial therapy after initial periodontal treatment. Journal of Clinical Periodontology, Copenhagen,v. 29, n. 6, p. 540-550, Jun. 2002.

SANDROS, J.; PAPAPANOU, P. N.; NANNMARK, U.; DAHLÉN, G: Porphyromonas gingivalis invades human pocket epithelium in vitro. Journal of Periodontal Research, Copenhagen, v.29, n.1, p.62-69, Jan. 1994.

SATO, S. Avaliação in vivo dos efeitos de um dispositivo de liberação lenta de metronidazol para tratamento de bolsas periodontais: parâmetros clínicos e 
microbiológicos em um modelo animal. (Doutorado). Materiais Dentários e Prótese, Universidade de São Paulo, Ribeirão Preto, 2006. 155 p.

SATO, S.; FONSECA, M. J.; CIAMPO, J. O.; JABOR, J.; PEDRAZZI, V. Metronidazole-containing gel for the treatment of periodontitis: an in vivo evaluation. Brazilian Oral Research, São Paulo, v.22, n.2, p.145-50, Apr-Jun. 2008.

SBORDONE L, RAMAGLIA L, GULLETTA E, IACONO V. Recolonization of the subgingival microflora after scaling and root planing in human periodontics. Journal of Periodontology, Chicago, v. 61, p. 579-84, Sep. 1990.

SCHÄTZLE, M.; FADDY, M. J.; CULLINAN, M. P.; SEYMOUR, G. J.; LANG, N. P.; BÜRGIN, W.; ANERUD, A.; BOYSEN, H.; LÖE, H. The clinical course of chronic periodontitis: V. Predictive factors in periodontal disease. Journal of Clinical Periodontology, Copenhagen, v.36, n.5, p. 365-71, May. 2009.

SCHERLUND, M.; MALMSTEN, M.; HOLMQVIST, P.; BRODIN, A. Thermoseting microemulsions and mixed micellar solutions as drug delivery systems for periodontal anesthesia. Int. J. Pharm., Amsterdam, v. 194, p. 103-116, 2000.

SEDLACEK, M. J.; WALKER, C. Antibiotic resistance in an in vitro subgingival biofilm model. Oral Microbiology and Immunology, Copenhagen , v.22, n.5, p. 333-9, 2007.

SHIFROVITCH, Y.; BINDERMAN, I.; BAHAR, H.; BERDICEVSKY, I.; ZILBERMAN, M. Metronidazole-loaded bioabsorbable films as local antibacterial treatment of infected periodontal pockets. . Journal of Periodontology, Chicago, v.80, n.2, p.330-7, 2009.

SHILOAH, J.; PATTERS, M. R. DNA probe analyses of the survival of selected periodontal pathogens following scaling root planning, and intra-pocket irrigation. Journal of Periodontology, Chicago, v. 65, p. 568-575, Jun. 1994.

SHILOAH, J.; PATTERS, M. R. Repopulation of periodontal pockets by microbial pathogens in the absence of supportive therapy. Journal of Periodontology, Chicago, vf.67, n.2, p.130-9, Feb. 1996.

SHILOAH, J.; PATTERS, M. R.; DEAN, J. W. 3RD, BLAND, P.; TOLEDO, G. The prevalence of Actinobacillus actinomycetemcomitans, Porphyromonas gingivalis, and Bacteroides forsythus in humans 1 year after 4 randomized treatment modalities. Journal of Periodontology, Chicago, v.69, n.12, p.1364-1372, Dec. 1998. 
SHINN, D. L. S. Metronidazole in acute ulcerative gingivitis. Lancet, I: 1191, 1962;

SHINN, D. L.; SQUIRES, S.; MCFADZEAN, J. A. The treatment of vincent's disease with metronidazole. The Dental Practitioner and Dental Record, Bristol, v.15, p. 275-80. Apr. 1965.

SIMON, G. L.; GORBACH, S. L. Intestinal health and disease. Gastroenterology, Baltimore, v.86, n.1, p.174-193, Jan. 1984.

SINGH, S.; ROY, S.; CHUMBER, S. K. Evaluation of two local drug delivery systems as adjuncts to mechanotherapy as compared to mechanotherapy alone in management of chronic periodontitis: A clinical, microbiological, and molecular study. Journal of Indian Society of Periodontology, Mumbai, v.13, n.3, p.126-32, Sep. 2009.

SIROTTO, T. O. Raspagem e alisamento radicular associada ao metronidazol sistêmico e ao bochecho com clorexidina no tratamento da periodontite crônica: estudo clínico e microbiológico. Dissertação (Mestrado) - Centro de PósGraduação, Pesquisa e Extensão, Universidade Guarulhos, 2008. 81 f.

SLOTS, J. The predominant cultivable microflora of advanced periodontitis. Scandinavian Journal of Dental Research, Copenhagen, v.85, n.2, p.114-21, JanFeb. 1977.

SOCRANSKY, S. S. Microbiology of periodontal disease - present status and future considerations. Journal of Periodontology, Chicago, v.48, n.9, p. 497-504, Sep. 1977.

SOCRANSKY, S. S.; HAFFAJEE, A. D. Microbial etiological agents of destructive periodontal diseases, Periodontology 2000, Copenhagen, v.5, p.78-111, Jun. 1994.

SOCRANSKY, S. S.; SMITH, C.; MARTIN, L.; PASTER, B. J.; DEWHIRST, F. E.; LEVIN, A. E. "Checkerboard" DNA-DNA hybridization. Biotechniques, Natick, v. 17, n. 4, p. 788-792, Oct. 1994.

SOCRANSKY S, S.; HAFFAJEE, A. D.; CUGINI, M. A.; SMITH, C.; KENT, JR. R L. Microbial complexes in subgingival plaque. Journal of Clinical Periodontology, Copenhagen, v. 25, n. 2, p.134-44, Feb. 1998.

SOCRANSKY, S. S.; HAFFAJEE, A. D.; Dental biofilms: dificult therapeutic targets. Periodontology 2000, Copenhagen, v.28, p. 12-55, 2002. 
SOCRANSKY, S. S.; HAFFAJEE, A. D., SMITH, C.; MARTIN, L.; HAFFAJEE, J. A.; UZEL, N. G.; GOODSON, J. M. Use of checkerboard DNA-DNA hybridization to study complex microbial ecosystems. Oral Microbiology and Immunology, Copenhagen, v.19, n. 6, p. 352-62, Dec. 2004.

SOCRANSKY, S. S.; HAFFAJEE, A. D. Periodontal microbial ecology. Periodontology 2000, Copenhagen, v. 38, p. 135-87, 2005.

SOMAYAJI, B. B.; JARIWALA, U.; JAYACHANDRAN, P.; VIDYALAKSHMI, D.; DUDHANI, R. V. Evaluation of antimicrobial efficacy and release pattern of tetracycline and metronidazole using a local delivery system. Journal of Periodontology, Chicago, v. 69, n. 4, p. 409-413, Apr. 1998.

SOSKOLNE, W. A. Subgingival delivery of therapeutic agents in the treatment of periodontal diseases Critical Reviews in Oral Biology and Medicine, Boca Raton, v.8, n.2, p.164-74, 1997.

SOSKOLNE, W. A.; CHAJEK, T.; FLASHNER, M.; LANDAU, I.; STABHOLTZ, A.; $\mathrm{KOLATCH}, \mathrm{B}$;; LERNER, E. I. An in vivo study of the chlorhexidine release profile of the PerioChip in the gingival crevicular fluid, plasma and urine. Journal of Clinical Periodontology, Copenhagen, v. 25, n. 12, p. 1017-1021, Dec. 1998.

SOSNIK, A.; COHN, D. Ethoxysilane-capped PEO-PPO-PEO triblocks: a new family of reverse thermo-responsive polymers. Biomaterials, Guilford, v. 25, n. 14, p. 28512858, Jun. 2004.

STANLEY, A.; WILSON, M.; NEWMAN, H. N. The in vitro effects of chlorhexidine on subgingival plaque bacteria. Journal of Clinical Periodontology, Copenhagen, v. 16, n. 4, p. 259-264, Apr. 1989.

STELZEL, M.; FLORĖS-DE-JACOBY, L. Topical metronidazole application compared with subgingival scaling. A clinical and microbiological study on recall patients. Journal of Clinical Periodontology, Copenhagen, v. 23, n. 1, p. 24-29, Jan. 1996.

STELZEL, M.; FLORĖS-DE-JACOBY, L. Topical metronidazole application as an adjunct to scaling and root planning. Journal of Clinical Periodontology, Copenhagen, v. 27, n. 6, p.447-452, Jun. 2000.

STOLLER, N. H.; JOHNSON, L. R.; TRAPNELL, S.; HARROLD, C. Q.; GARRETT, $S$. The pharmacokinetic profile of a biodegradable controlled-release delivery system containing doxycycline compared to systemically delivered doxycycline in gingival crevicular fluid, saliva, and serum. Journal of Periodontology, Chicago, v. 69, n. 10, p. 1085-1091, Oct. 1998. 
STOLTZE, K. Concentration of metronidazole in periodontal pockets after application of a metronidazole $25 \%$ dental gel. Journal of Clinical Periodontology, Copenhagen, v. 19, n. 9 Pt 2, p. 698-701, Oct. 1992.

STOLTZE, K. Elimination of Elyzol 25\% Dental gel matrix from periodontal pockets. Journal of Clinical Periodontology, Copenhagen, v. 22, n. 3, p. 185-187, Mar. 1995.

STOLTZE, K.; STELLFELD, M. Systemic absorption of metronidazole after application of a metronidazole $25 \%$ dental gel. Journal of Clinical Periodontology, Copenhagen, v. 19, n. 9 Pt 2, p. 693-697, Oct. 1992.

TALLY, F. P.; SUTTER, V. L.; FINEGOLD, S. M. Treatment of anaerobic infections with metronidazole. Antimicrobial Agents and Chemotherapy, Washington, v.7, n.5, p.672-5, May. 1975.

TANNER, A. C.; DZINK, J. L.; EBERSOLE, J. L.; SOCRANSKY, S. S. Wolinella recta, campylobacter concisus, bacteroides gracilis, and Eikenella corrodens from periodontal lesions. Journal of Clinical Periodontology, Copenhagen, v.22, n.4, p.327-30, Jul. 1987.

TELES, R. P.; HAFFAJEE, A. D.; SOCRANSKY, S. S. Microbiological goals of periodontal therapy. Periodontology 2000, Copenhagen, v.42, p. 180-218, 2006.

TELES, R. P.; GURSKY, L. C.; FAVERI, M.; ROSA, E. A.; TELES, F. R.; FERES, M.; SOCRANSKY, S. S.; HAFFAJEE, A. D. Relationships between subgingival microbiota and GCF biomarkers in generalized aggressive periodontitis. Journal of Clinical Periodontology, Copenhagen, v. 37, v.4, p. 313-23, Apr. 2010.

THEILADE, E.; WRIGHT, W. H.; JENSEN, S. B.; LÖE, H. Experimental gingivits in man II. A longitudinal clinical and bacteriological investigation. Journal of Periodontol Research, Copenhagen, v.1, p.1-13, 1966.

THEILADE, E. The non-specific theory in microbial etiology of inflammatory periodontal diseases. Journal of Clinical Periodontology, Copenhagen, v.13, n.10, p. 905-11, Nov. 1986.

TENENBAUM, H.; JEHL, F., GALLION, C.; DAHAN, M. Amoxicillin and clavulanic acid concentrations in gingival crevicular fluid. Journal of Clinical Periodontology, Copenhagen, v. 24, n.11, p. 804-807, Nov. 1997.

TIWARI, G.; TIWARI, R., RAI, A. K. Studies on development of controlled delivery of combination drug(s) to periodontal pocket. Indian Journal of Dental Research, Ahmedabad, v.21, n.1, p.72-83, Jan-Mar. 2010. 
Uitto, V. J.; Overall, C. M.; McCulloch, C. Proteolytic host cell enzymes in gingival crevice fluid. Periodontology 2000, Copenhagen, v.31, n.1, p.77-104, 2003.

VAN OOSTEN, M. A.; NOTTEN, F. J.; MIKX, F. H. Metronidazole concentrations in human plasma, saliva, and gingival crevice fluid after a single dose. Journal of Dental Research, Chicago , v.65, n.12, p1420-1423. Dec. 1986.

VANDEKERCKHOVE, B.N.; QUIRYNEN, M.; VAN STEENBERGHE, D. The use locally delivered minocycline in the treatment of chronic periodontitis: a review of the literature. Journal of Clinical Periodontology, Copenhagen, v. 25, n. 11 Pt 2, p. 964-968, Nov. 1998.

WAN YUSOF, W. Z. A.; NEWMAN, H. N.; STRAHAN, J. D.; COVENTRY, J. F. Subgingival metronidazole in dialysis tubing and subgingival chlorhexidine irrigation in the control of chronic inflammatory periodontal disease. Journal of Clinical Periodontology, Copenhagen, v. 11, n. 3, p. 166-175, Mar. 1984.

WILDER, R. S. A new option for local delivery. Antimicrobials, such as minocycline microspheres, can enhance the effectiveness of mechanical therapy in treating chronic periodontitis. Texas Dental Journal, Dallas, v.120, n.10, p.984-7, Oct. 2003.

WEISS, S. J. Tissue destruction by neutrophils. The New England Journal of Medicine, Boston, v. 320, n. 6, p. 365-376, Feb 9. 1989.

YEWEY, G. L.; DUYSEN, E. G.; COX, S. M.; DUNN, R. L. Delivery of proteins from a controlled release injectable implant. Pharmaceutical Biotechnology, New York, v. 10, p. 93-117, 1997.

YEUNG, F. I.; NEWMAN, H. N.; ADDY, M. Subgingival metronidazole in acrylic resin vs. chlorhexidine irrigation in the control of chronic periodontitis. Journal of Periodontology, Chicago, v. 54, n. 11, p. 651-657, Nov. 1983.

ZAMBON, J. J. Periodontal Diseases: Microbial Factors. Annals of Periodontology, Chicago, vol. 1, n.1 p.879-925, Nov. 1996.

ZEE, K.Y.; SAMARAYABE, L.P.; ATTSTROM, R. Predominant cultivable supragingival plaque in Chinese rapid and slow plaque formers. Journal of Clinical Periodontology, Copenhagen, v. 23, n. 11, p. 1025-1031, Nov. 1996.

ZIJNGE, V.; MEIJER ,H. F.; LIE, M. A.; TROMP, J. A.; DEGENER, J. E.; HARMSEN, $H$. J.; ABBAS, F. The recolonization hypothesis in a full-mouth or multiple-session treatment protocol: a blinded, randomized clinical trial. Journal of Clinical Periodontology, Copenhagen, v.37, n.6, p.518-25, Jun. 2010. 
Apêndices 


\section{APÊNDICES}

APÊNDICE A - Quadros demonstrativos da análise estatística realizada, gerada pelo programa NCSS

\section{Profundidade de sondagem}

\begin{tabular}{|c|c|c|c|}
\hline \multicolumn{4}{|c|}{ Means and Standard Error Section } \\
\hline Term & Count & Mean & $\begin{array}{l}\text { Standard } \\
\text { Error }\end{array}$ \\
\hline All & 63 & 4,884152 & \\
\hline \multicolumn{4}{|l|}{ A: Tratamento } \\
\hline GEL & 31 & 5,533928 & 0,3155737 \\
\hline RAR & 32 & 4,234375 & 0,3106037 \\
\hline \multicolumn{4}{|l|}{ C: Tempo } \\
\hline$T=+30 d$ & 16 & 4,33125 & 0,2178896 \\
\hline$T=+7 d$ & 16 & 4,89375 & 0,2178896 \\
\hline$T=+90 d$ & 15 & 4,092857 & 0,2250354 \\
\hline$T=-7 d$ & 16 & 6,21875 & 0,2178896 \\
\hline \multicolumn{4}{|c|}{ AC: Tratamento,Tempo } \\
\hline $\mathrm{GEL}, \mathrm{T}=+30 \mathrm{~d}$ & 8 & 5,0125 & 0,3081424 \\
\hline $\mathrm{GEL}, \mathrm{T}=+7 \mathrm{~d}$ & 8 & 5,7125 & 0,3081424 \\
\hline$G E L, T=+90 d$ & 7 & 4,585714 & 0,3294181 \\
\hline$G E L, T=-7 d$ & 8 & 6,825 & 0,3081424 \\
\hline$R A R, T=+30 d$ & 8 & 3,65 & 0,3081424 \\
\hline$R A R, T=+7 d$ & 8 & 4,075 & 0,3081424 \\
\hline$R A R, T=+90 d$ & 8 & 3,6 & 0,3081424 \\
\hline$R A R, T=-7 d$ & 8 & 5,6125 & 0,3081424 \\
\hline
\end{tabular}

Analysis of Variance table

\begin{tabular}{|c|c|c|c|c|c|c|}
\hline Source & DF & $\begin{array}{l}\text { Sum of } \\
\text { Squares }\end{array}$ & $\begin{array}{l}\text { Mean } \\
\text { Square }\end{array}$ & F-Ratio & $\begin{array}{l}\text { Prob } \\
\text { Level }\end{array}$ & $\begin{array}{c}\text { Power } \\
(\text { Alpha }=0,05)\end{array}$ \\
\hline A: Tratamento & 1 & 26,54737 & 26,54737 & 8,6 & $0,010919^{*}$ & 0,778406 \\
\hline$B(A)$ : Paciente & 14 & 43,22065 & 3,08719 & & & \\
\hline C: Tempo & 3 & 42,73026 & 14,24342 & 18,75 & $0,000000^{*}$ & 0,999997 \\
\hline$A C$ & 3 & 0,8702633 & 0,2900878 & 0,38 & 0,76657 & 0,118802 \\
\hline $\mathrm{BC}(\mathrm{A})$ & 41 & 31,14417 & 0,7596138 & & & \\
\hline S & 0 & & & & & \\
\hline Total (Adjusted) & 62 & 145,6022 & & & & \\
\hline Total & 63 & & & & & \\
\hline
\end{tabular}

* Term significant at alpha $=0,05$ 


\begin{tabular}{|c|c|c|c|}
\hline \multicolumn{4}{|c|}{ Tukey-Kramer Multiple-Comparison Test } \\
\hline \multicolumn{4}{|c|}{ Response: Bolsa } \\
\hline \multicolumn{4}{|c|}{ Term AC: Tratamento,Tempo } \\
\hline \multirow[t]{2}{*}{ Alpha $=0,050$} & Error Term $=\mathrm{BC}(\mathrm{A})$ & $\mathrm{DF}=41 \quad \mathrm{MSE}=0,7$ & 38 Critical Value $=4,5147$ \\
\hline & & & Different From \\
\hline Group & Count & Mean & Groups \\
\hline $\mathrm{RAR}, \mathrm{T}=+90 \mathrm{~d}$ & 8 & 3,6 & $\begin{array}{l}(G E L, T=+30 d),(R A R, T=-7 d),(G E L, T=+7 d) \\
(G E L, T=-7 d)\end{array}$ \\
\hline $\mathrm{RAR}, \mathrm{T}=+30 \mathrm{~d}$ & 8 & 3,65 & $(R A R, T=-7 d),(G E L, T=+7 d),(G E L, T=-7 d)$ \\
\hline $\mathrm{RAR}, \mathrm{T}=+7 \mathrm{~d}$ & 8 & 4,075 & $(R A R, T=-7 d),(G E L, T=+7 d),(G E L, T=-7 d)$ \\
\hline$G E L, T=+90 d$ & 7 & 4,585714 & $(G E L, T=-7 d)$ \\
\hline GEL, $T=+30 \mathrm{~d}$ & 8 & 5,0125 & $(R A R, T=+90 d),(G E L, T=-7 d)$ \\
\hline $\mathrm{RAR}, \mathrm{T}=-7 \mathrm{~d}$ & 8 & 5,6125 & $(R A R, T=+90 d),(R A R, T=+30 d),(R A R, T=+7 d)$ \\
\hline $\mathrm{GEL}, \mathrm{T}=+7 \mathrm{~d}$ & 8 & 5,7125 & $(R A R, T=+90 d),(R A R, T=+30 d),(R A R, T=+7 d)$ \\
\hline GEL,T=-7d & 8 & 6,825 & $\begin{array}{l}(R A R, T=+90 d),(R A R, T=+30 d),(R A R, T=+7 d) \\
(G E L, T=+90 d),(G E L, T=+30 d)\end{array}$ \\
\hline
\end{tabular}

Notes: This report provides multiple comparison tests for all pairwise differences betweenthe means

\section{Nível Clínico de Inserção}

\begin{tabular}{|llll|}
\hline \multicolumn{2}{l}{ Means and Standard Error Section } & & Standard \\
Term & Count & $\begin{array}{l}\text { Mean } \\
\text { Error }\end{array}$ \\
All & 63 & 5,983036 & \\
A: Tratamento & & & \\
GEL & 31 & 6,522321 & 0,3956329 \\
RAR & 32 & 5,44375 & 0,389402 \\
C: Tempo & & 5,58125 & 0,1827928 \\
T=+30d & 16 & 6,10625 & 0,1827928 \\
T=+7d & 16 & 5,294643 & 0,1887876 \\
T=+90d & 15 & 6,95 & 0,1827928 \\
T=-7d & 16 & & \\
AC: Tratamento,Tempo & & 6,1375 & 0,2585081 \\
GEL,T=+30d & 8 & 6,8375 & 0,2585081 \\
GEL, $T=+7 d$ & 8 & 5,614286 & 0,2763568 \\
GEL,T=+90d & 7 & 7,5 & 0,2585081 \\
GEL,T=-7d & 8 & 5,025 & 0,2585081 \\
RAR, $T=+30 d$ & 8 & 5,375 & 0,2585081 \\
RAR, $T=+7 d$ & 8 & 4,975 & 0,2585081 \\
RAR, $T=+90 d$ & 8 & 6,4 & 0,2585081 \\
RAR, $T=-7 d$ & 8 & & \\
\hline
\end{tabular}




\section{Analysis of Variance Table}

\begin{tabular}{|lllllc|}
\hline $\begin{array}{l}\text { Source } \\
\text { Term }\end{array}$ & DF & $\begin{array}{l}\text { Sum of } \\
\text { Squares }\end{array}$ & $\begin{array}{l}\text { Mean } \\
\text { Square }\end{array}$ & $\begin{array}{l}\text { Power } \\
\text { F-Ratio }\end{array}$ & $\begin{array}{l}\text { Prob } \\
\text { Level } \\
\text { (Alpha=0,05) }\end{array}$ \\
A: Tratamento & 1 & 18,28652 & 18,28652 & 3,77 & 0,072626 \\
B(A): Paciente & 14 & 67,932 & 4,852286 & & 0,439685 \\
C: Tempo & 3 & 24,85425 & 8,284749 & 15,5 & $0,000001^{*}$ \\
AC & 3 & 1,315602 & 0,4385341 & 0,82 & 0,490192 \\
BC(A) & 41 & 21,91907 & 0,5346114 & & 0,2116997 \\
S & 0 & & & \\
Total (Adjusted) & 62 & 135,0622 & & \\
Total & 63 & & & & \\
\hline
\end{tabular}

${ }^{*}$ Term significant at alpha $=0,05$

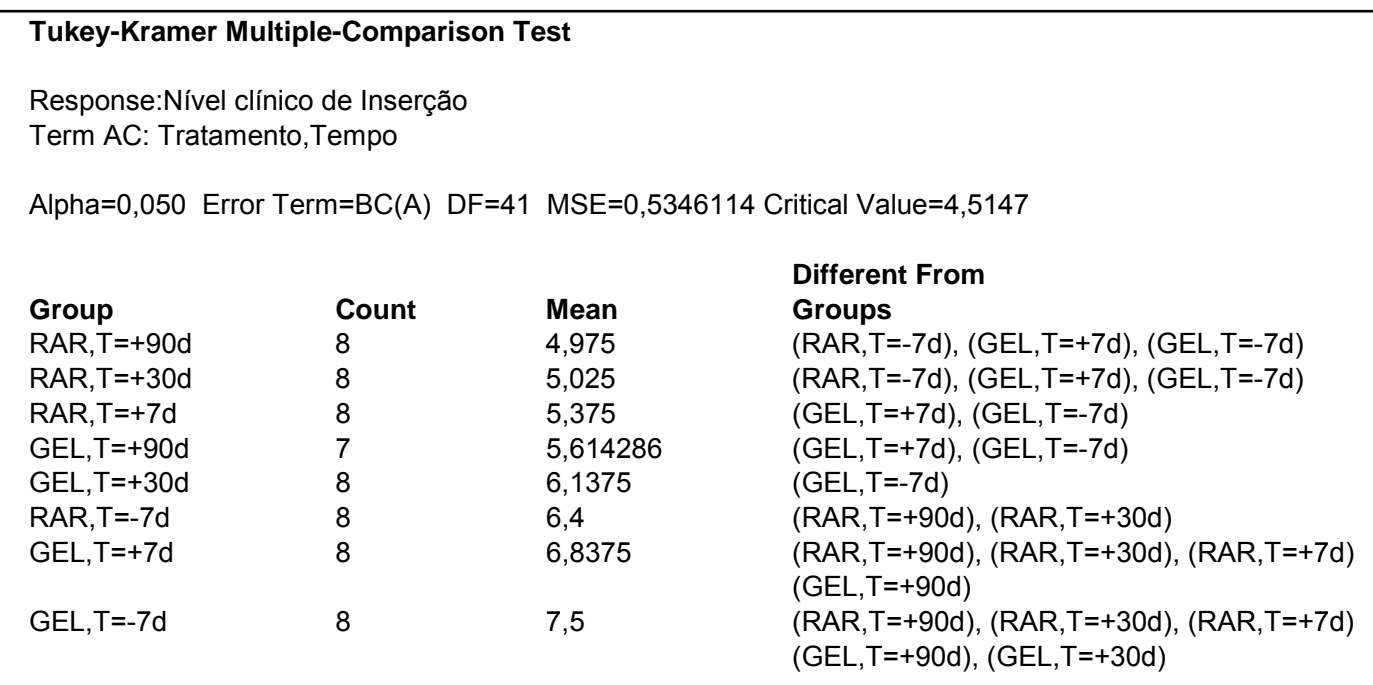

Notes: This report provides multiple comparison tests for all pairwise differences betweenthe means 
APENDICE B - Quadros demonstrativos da análise estatística realizada, gerada pelo Programa GraphPad Instat

\section{Microbiológico (Análise das contagens bacterianas sem discriminação entre as espécies)}

\section{One-way Analysis of Variance (ANOVA)}

The $P$ value is $<0.0001$, considered extremely significant.

Variation among column means is significantly greater than expected

by chance.

\section{Tukey-Kramer Multiple Comparisons Test}

If the value of $q$ is greater than 4.085 then the $P$ value is less than 0.05 .

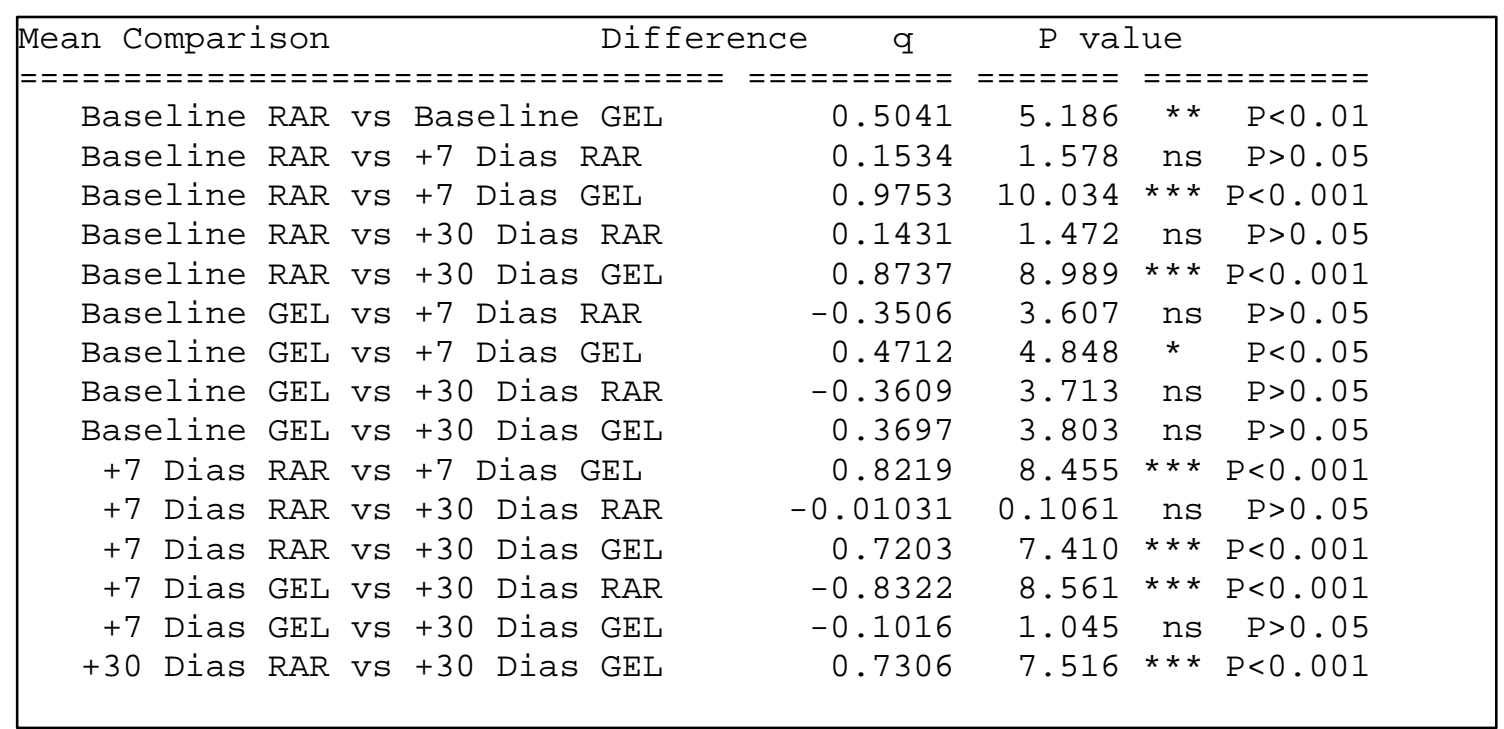




\begin{tabular}{|c|c|c|c|c|c|}
\hline & \multirow{2}{*}{\multicolumn{2}{|c|}{ Difference }} & Mean & \multicolumn{2}{|c|}{ 95\% Confidence } \\
\hline =ー=ー==ニ=ニ== & & & $\begin{array}{l}\text { Difference } \\
========\end{array}$ & 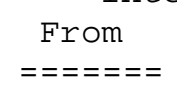 & $\begin{array}{c}\text { To } \\
=====\end{array}$ \\
\hline Baseline & RAR & - Baseline GEL & 0.5041 & 0.1070 & 0.9011 \\
\hline Baseline & RAR & - +7 Dias RAR & 0.1534 & -0.2436 & 0.5505 \\
\hline Baseline & RAR & - +7 Dias GEL & 0.9753 & 0.5783 & 1.372 \\
\hline Baseline & RAR & - +30 Dias RAR & 0.1431 & -0.2539 & 0.5402 \\
\hline Baseline & RAR & - +30 Dias GEL & 0.8737 & $\odot .4767$ & 1.271 \\
\hline Baseline & GEL & - +7 Dias RAR & -0.3506 & -0.7477 & $\odot .04641$ \\
\hline Baseline & GEL & - +7 Dias GEL & 0.4712 & 0.07421 & 0.8683 \\
\hline Baseline & GEL & - +30 Dias RAR & -0.3609 & -0.7580 & 0.03610 \\
\hline Baseline & GEL & - +30 Dias GEL & $\odot .3697$ & $-\odot .02735$ & 50.7667 \\
\hline +7 Dias & RAR & - +7 Dias GEL & 0.8219 & 0.4248 & 1.219 \\
\hline +7 Dias & RAR & - +30 Dias RAR & -0.01031 & -0.4074 & 0.3867 \\
\hline +7 Dias & RAR & - +30 Dias GEL & 0.7203 & $\odot .3233$ & 1.117 \\
\hline +7 Dias & GEL & - +30 Dias RAR & -0.8322 & -1.229 & -0.4351 \\
\hline +7 Dias & GEL & - +30 Dias GEL & -0.1016 & -0.4986 & 0.2955 \\
\hline +30 Dias & RAR & - +30 Dias GEL & 0.7306 & 0.3336 & 1.128 \\
\hline
\end{tabular}

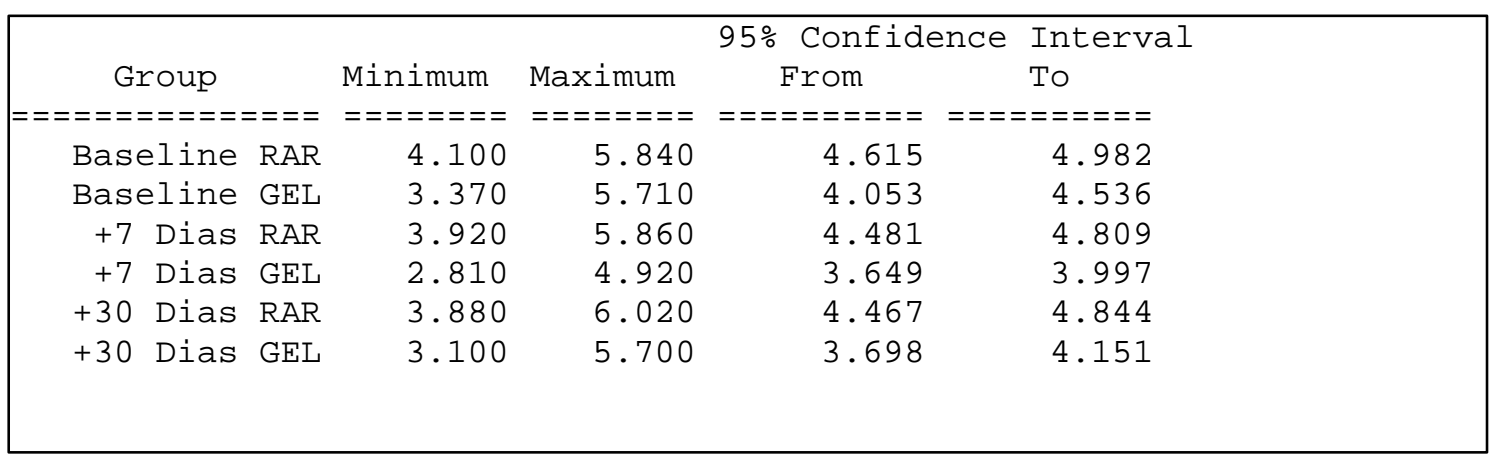

\section{Microbiológico (Análise das contagens bacterianas individuais)}

Obs: A analise estatística foi realizada para todas as espécies avaliadas, mas neste apêndice estão demosntradas apenas as principais espécies periodontopatogênicas e as espécies que exibiram diferença significante em função do tempo e tratamento.

\section{A. actinomycetemcomitans a}

Kruskal-Wallis Test (Nonparametric ANOVA)

The $P$ value is 0.4288 , considered not significant.

Variation among column medians is not significantly greater than expected by chance. 


\begin{tabular}{|c|c|c|c|}
\hline \multicolumn{4}{|c|}{ Calculation detail } \\
\hline 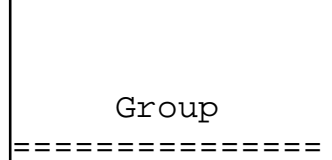 & $\begin{array}{l}\text { Number } \\
\text { of } \\
\text { Points } \\
=====\end{array}$ & $\begin{array}{l}\text { Sum } \\
\text { of } \\
\text { Ranks } \\
======\end{array}$ & $\begin{array}{l}\text { Mean } \\
\text { of } \\
\text { Ranks } \\
======\end{array}$ \\
\hline Baseline RAR -7 & 16 & 881.00 & 55.063 \\
\hline Baseline GEL -7 & 16 & 705.00 & 44.063 \\
\hline RAR 7 Dias & 16 & 807.00 & 50.438 \\
\hline GEL 7 Dias & 16 & 608.00 & $38.00 \odot$ \\
\hline RAR 30 Dias & 16 & 899.00 & 56.188 \\
\hline Gel 30 Dias & 16 & 756.00 & 47.250 \\
\hline
\end{tabular}

Kruskal-Wallis Statistic $\mathrm{KW}=4.895$

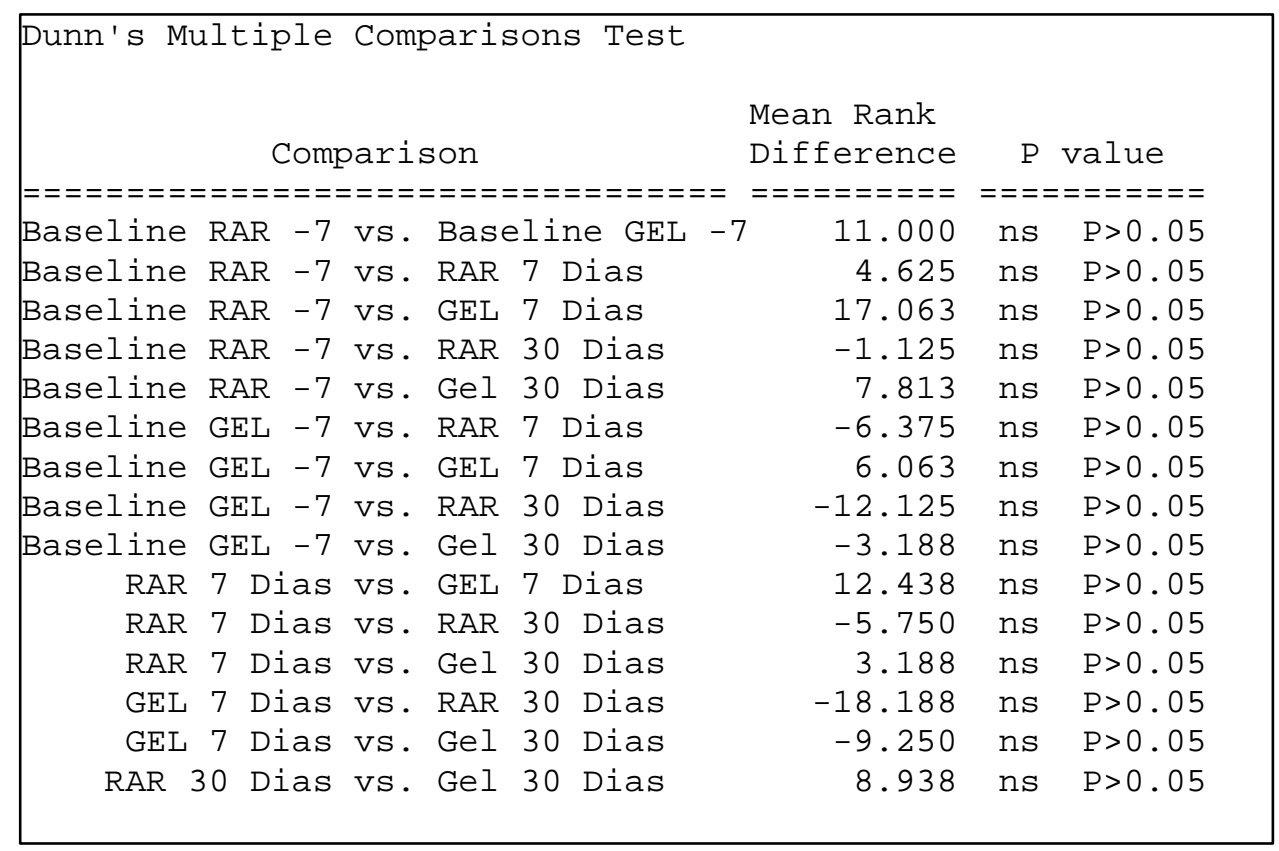

\begin{tabular}{|c|c|c|c|c|}
\hline \multicolumn{5}{|l|}{ Summary of Data } \\
\hline 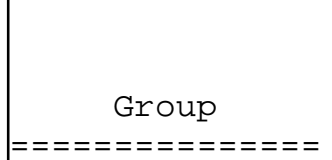 & $\begin{array}{c}\text { Number } \\
\text { of } \\
\text { Points } \\
=====\end{array}$ & $\begin{array}{c}\text { Median } \\
=======\end{array}$ & $\begin{array}{l}\text { Minimum } \\
=======\end{array}$ & $\begin{array}{l}\text { Maximum } \\
==ニ====\end{array}$ \\
\hline Baseline RAR -7 & 16 & $546 \odot 43$ & 201381 & 694843 \\
\hline Baseline GEL -7 & 16 & 508681 & 219911 & 729464 \\
\hline RAR 7 Dias & 16 & 530561 & 200322 & 551943 \\
\hline GEL 7 Dias & 16 & 503077 & 240942 & 563245 \\
\hline RAR 30 Dias & 16 & 546093 & 221839 & 950854 \\
\hline Gel 30 Dias & 16 & 509480 & 196501 & 663525 \\
\hline
\end{tabular}




\section{A. Actinomycetemcomitans $b$}

Kruskal-Wallis Test (Nonparametric ANOVA)

The $P$ value is 0.0479 , considered significant.

Variation among column medians is significantly greater than expected by chance.

\begin{tabular}{|cccc|}
\hline Calculation detail & & \\
& $\begin{array}{c}\text { Number } \\
\text { of }\end{array}$ & \multicolumn{1}{c|}{$\begin{array}{c}\text { Sum } \\
\text { of } \\
\text { Points } \\
\text { Ranks }\end{array}$} & $\begin{array}{c}\text { Mean } \\
\text { of } \\
\text { Ranks }\end{array}$ \\
Group & $\begin{array}{c}\text { Ranks } \\
=============\end{array}$ & $=====$ \\
Baseline RAR & 16 & 897.00 & 56.063 \\
Baseline GEL & 16 & 648.00 & 40.500 \\
RAR 7 Dias & 16 & 917.00 & 57.313 \\
GEL 7 dias & 16 & 537.00 & 33.563 \\
RAR 30 dias & 16 & 941.00 & 58.813 \\
GEL30 dias & 16 & 716.00 & 44.750 \\
& & & \\
\hline
\end{tabular}

Kruskal-Wallis Statistic $\mathrm{KW}=11.183$

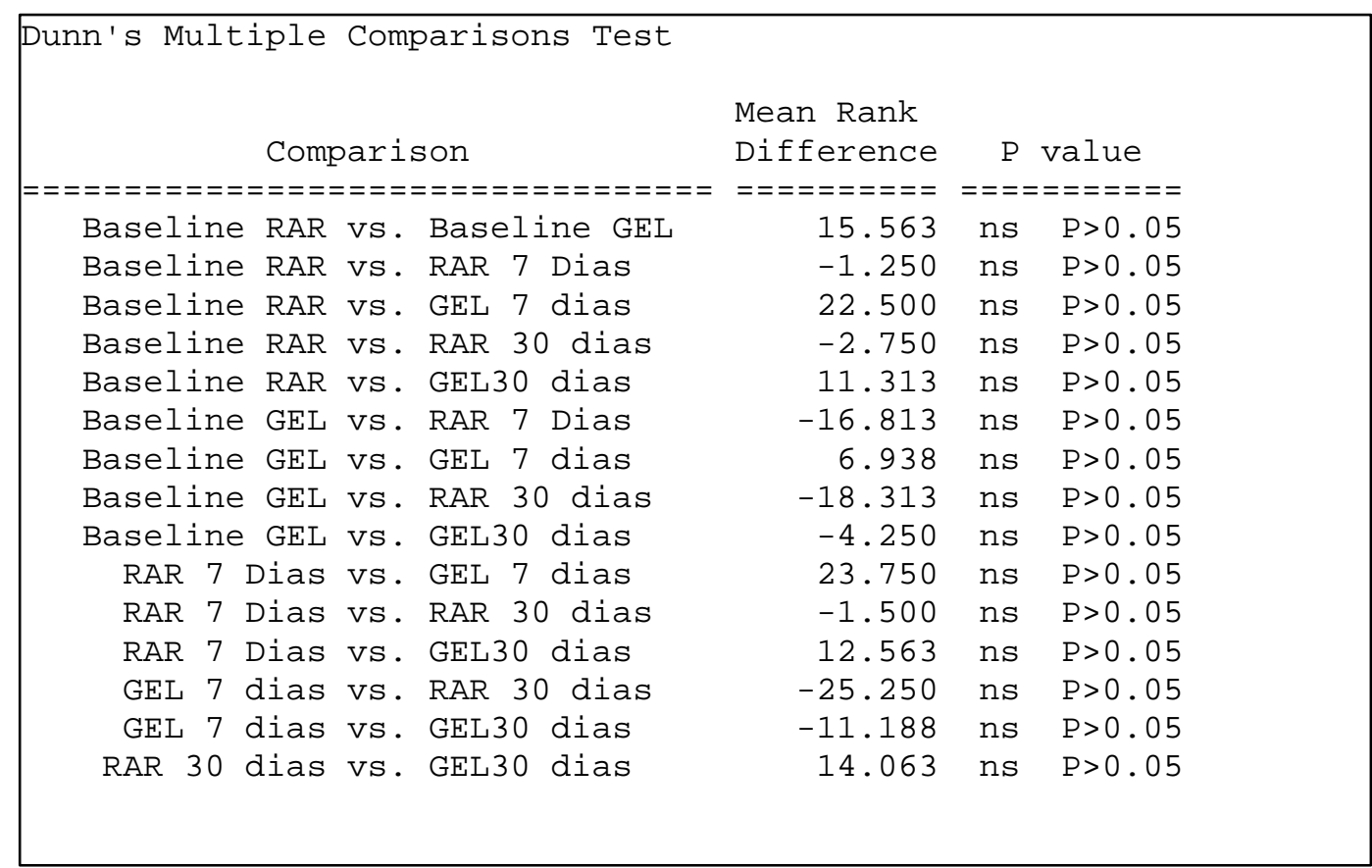




\begin{tabular}{|c|c|c|c|c|}
\hline \multicolumn{5}{|c|}{ Summary of Data } \\
\hline 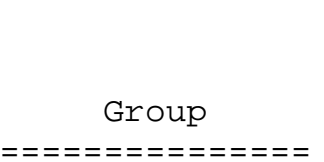 & $\begin{array}{c}\text { Number } \\
\text { of } \\
\text { Points } \\
=====\end{array}$ & $\begin{array}{c}\text { Median } \\
========\end{array}$ & $\begin{array}{l}\text { Minimum } \\
=======\end{array}$ & $\begin{array}{l}\text { Maximum } \\
========\end{array}$ \\
\hline Baseline RAR & 16 & 548327 & 310763 & 956174 \\
\hline Baseline GEL & 16 & 503329 & 306052 & 1014433 \\
\hline RAR 7 Dias & 16 & 547185 & 371202 & 873162 \\
\hline GEL 7 dias & 16 & 505431 & 102538 & 766483 \\
\hline RAR 30 dias & 16 & 547540 & 454175 & 901893 \\
\hline GEL30 dias & 16 & 509651 & 306747 & 842689 \\
\hline
\end{tabular}

\section{E. corrodens}

Kruskal-Wallis Test (Nonparametric ANOVA)

The $P$ value is 0.0010 , considered extremely significant. Variation among column medians is significantly greater than expected by chance.

\begin{tabular}{|crrr|}
\hline Calculation detail & & \\
Number & $\begin{array}{l}\text { Sum } \\
\text { of } \\
\text { Points }\end{array}$ & $\begin{array}{c}\text { Mean } \\
\text { of } \\
\text { Ranks }\end{array}$ & $\begin{array}{c}\text { of } \\
\text { Ranks }\end{array}$ \\
Group & $===========$ \\
$=====$ & $=====$ & $=====$ \\
Baseline RAR & 16 & 1067.0 & 66.688 \\
Baseline GEL & 16 & $892.0 \odot$ & 55.750 \\
RAR 7 Dias & 16 & $846.0 \odot$ & 52.875 \\
GEL 7 Dias & 16 & 414.00 & 25.875 \\
RAR 30 dias & 16 & $803.0 \odot$ & 50.188 \\
GEL 30 dias & 16 & $634.0 \odot$ & 39.625 \\
& & & \\
\hline
\end{tabular}

Kruskal-Wallis Statistic $\mathrm{KW}=20.536$

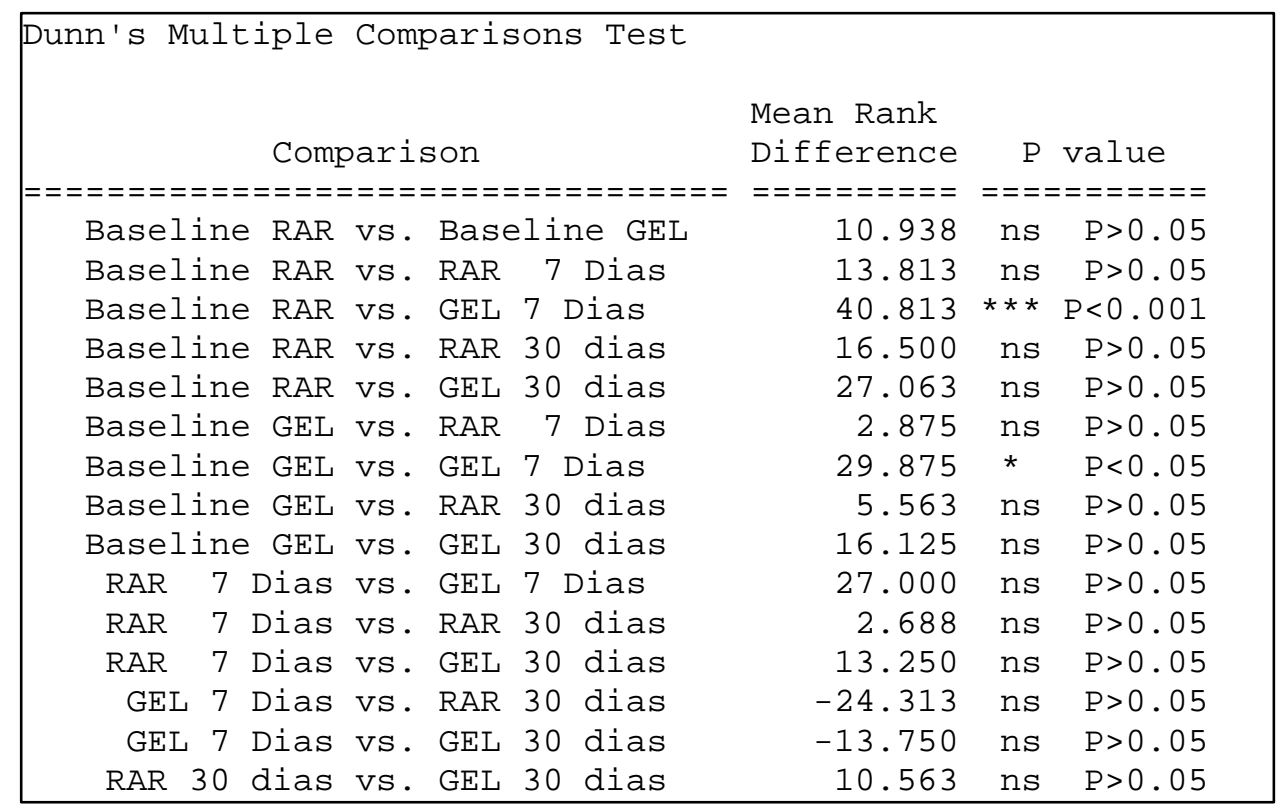




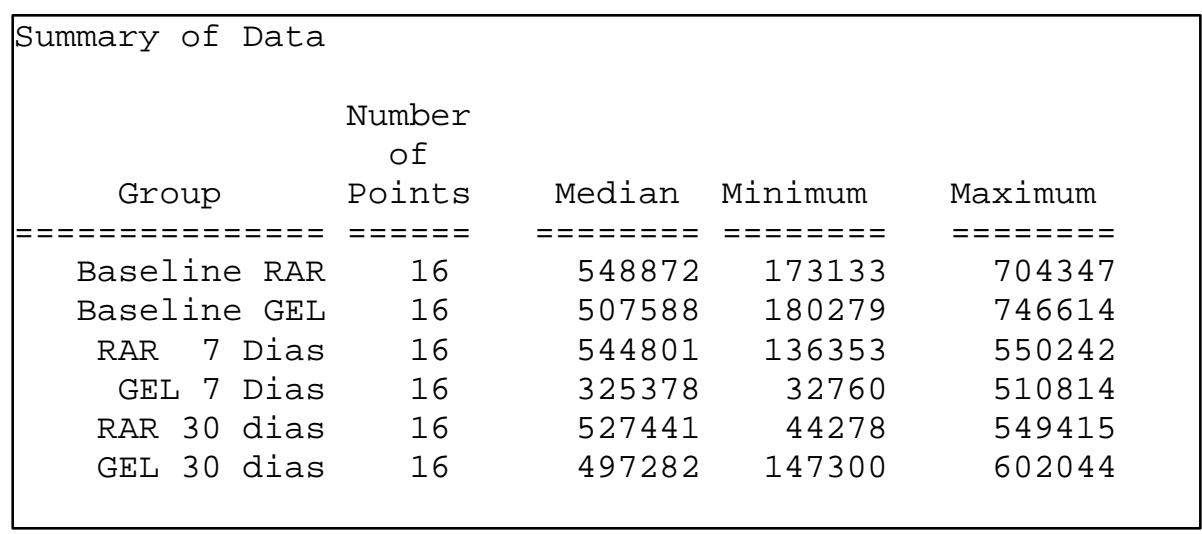

\section{P. gingivalis}

Kruskal-Wallis Test (Nonparametric ANOVA)

The $P$ value is 0.0277 , considered significant.

Variation among column medians is significantly greater than expected by chance.

\begin{tabular}{|c|c|c|c|}
\hline \multicolumn{4}{|c|}{ Calculation detail } \\
\hline 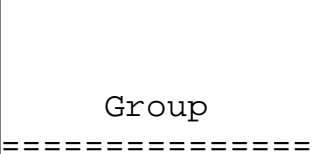 & $\begin{array}{l}\text { Number } \\
\text { of } \\
\text { Points } \\
======\end{array}$ & $\begin{array}{l}\text { Sum } \\
\text { of } \\
\text { Ranks } \\
======\end{array}$ & $\begin{array}{l}\text { Mean } \\
\text { of } \\
\text { Ranks } \\
\text { ==ニ===- }\end{array}$ \\
\hline Baseline RAR & 16 & $970.0 \odot$ & 60.625 \\
\hline Baseline GEL & 16 & 726.00 & 45.375 \\
\hline RAR 7 Dias & 16 & 917.00 & 57.313 \\
\hline GEL 7 Dias & 16 & 561.00 & 35.063 \\
\hline RAR 30 Dias & 16 & 895.00 & 55.938 \\
\hline GEL 30 dias & 16 & 587.00 & 36.688 \\
\hline
\end{tabular}

Kruskal-Wallis Statistic $\mathrm{KW}=12.574$ 


\begin{tabular}{|c|c|c|c|c|c|c|c|}
\hline \multicolumn{8}{|c|}{ Dunn's Multiple Comparisons Test } \\
\hline \multicolumn{5}{|c|}{ Comparison } & $\begin{array}{l}\text { Mean Rank } \\
\text { Difference } \\
========\end{array}$ & \multicolumn{2}{|c|}{$P$ value } \\
\hline Baseline & RAR & vs. & Baselin & he GEL & 15.250 & ns & $P>0.05$ \\
\hline Baseline & RAR & VS. & RAR 7 D & Dias & 3.313 & ns & $P>0.05$ \\
\hline Baseline & RAR & VS. & GEL $7 \mathrm{D}$ & Dias & 25.563 & ns & $P>0.05$ \\
\hline Baseline & RAR & VS. & RAR 30 & Dias & 4.688 & ns & $P>0.05$ \\
\hline Baseline & RAR & vs. & GEL 30 & dias & 23.938 & ns & $P>0.05$ \\
\hline Baseline & GEL & VS. & RAR $7 \mathrm{D}$ & Dias & -11.938 & ns & $P>0.05$ \\
\hline Baseline & GEL & VS. & GEL $7 \mathrm{D}$ & Dias & 10.313 & ns & $P>0.05$ \\
\hline Baseline & GEL & VS. & RAR 30 & Dias & -10.563 & ns & $P>0.05$ \\
\hline Baseline & GEL & vs. & GEL 30 & dias & 8.688 & ns & $P>0.05$ \\
\hline RAR 7 & Dias & vs. & GEL 7 & Dias & 22.250 & ns & $P>0.05$ \\
\hline RAR 7 & Dias & VS. & RAR 30 & Dias & 1.375 & ns & $P>0.05$ \\
\hline RAR 7 & Dias & vs. & GEL 30 & dias & 20.625 & ns & $P>0.05$ \\
\hline GEL 7 & Dias & VS. & RAR 30 & Dias & -20.875 & ns & $P>0.05$ \\
\hline GEL 7 & Dias & VS. & GEL 30 & dias & -1.625 & ns & $P>0.05$ \\
\hline RAR 30 & Dias & VS. & GEL 30 & dias & 19.250 & ns & $P>0.05$ \\
\hline
\end{tabular}

\section{P. intermedia}

Kruskal-Wallis Test (Nonparametric ANOVA)

The $P$ value is 0.0218 , considered significant.

Variation among column medians is significantly greater than expected by chance.

\begin{tabular}{|c|c|c|c|}
\hline \multicolumn{4}{|c|}{ Calculation detail } \\
\hline 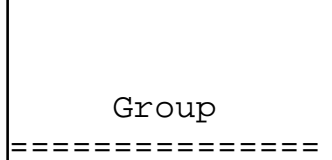 & $\begin{array}{c}\text { Number } \\
\text { of } \\
\text { Points } \\
======\end{array}$ & $\begin{array}{l}\text { Sum } \\
\text { of } \\
\text { Ranks } \\
======\end{array}$ & $\begin{array}{l}\text { Mean } \\
\text { of } \\
\text { Ranks } \\
======\end{array}$ \\
\hline Baseline RAR & 16 & $929.0 \odot$ & 58.063 \\
\hline Baseline GEL & 16 & 731.00 & 45.688 \\
\hline RAR 7 Dias & 16 & 900.00 & 56.250 \\
\hline GEL 7 Dias & 16 & 572.00 & 35.750 \\
\hline RAR 30 Dias & 16 & 963.00 & 60.188 \\
\hline GEL 30 dias & 16 & 561.00 & 35.063 \\
\hline
\end{tabular}

Kruskal-Wallis Statistic $\mathrm{KW}=13.178$ 


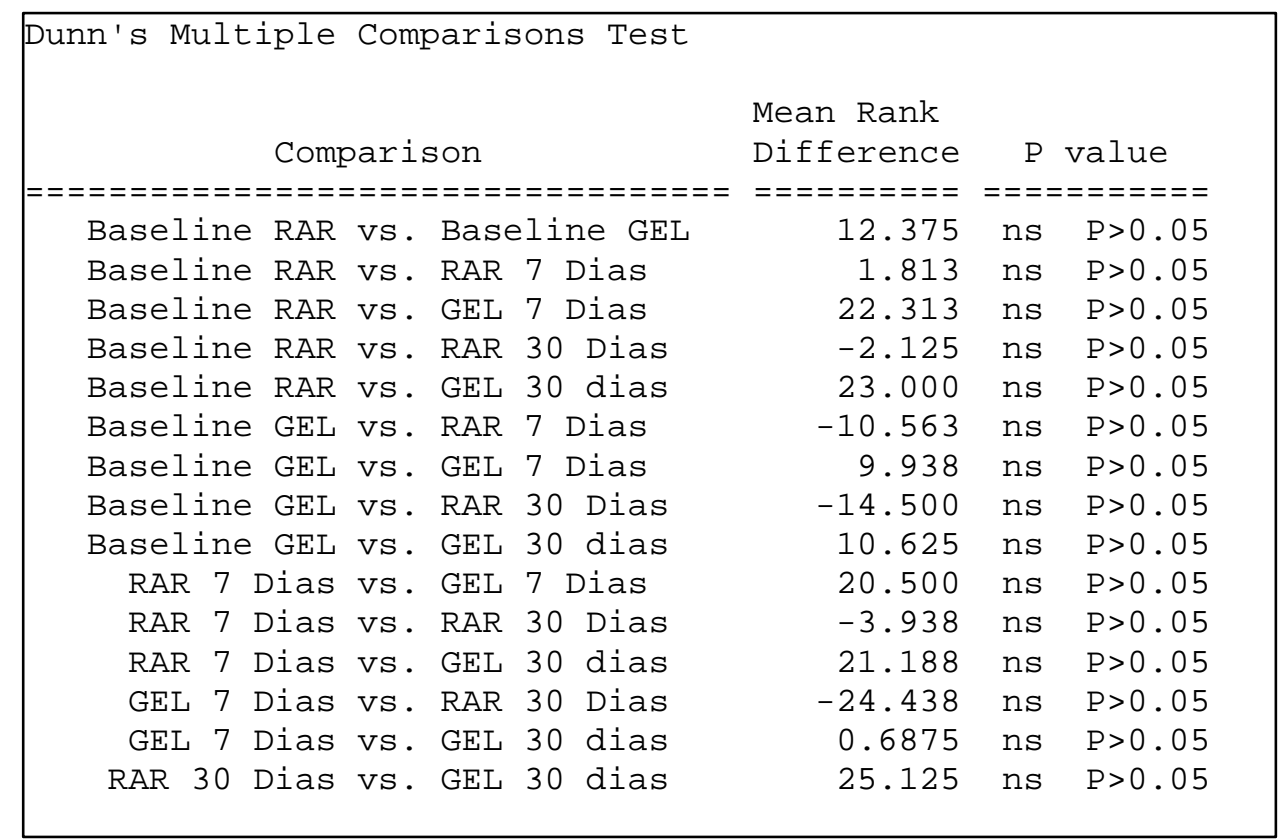

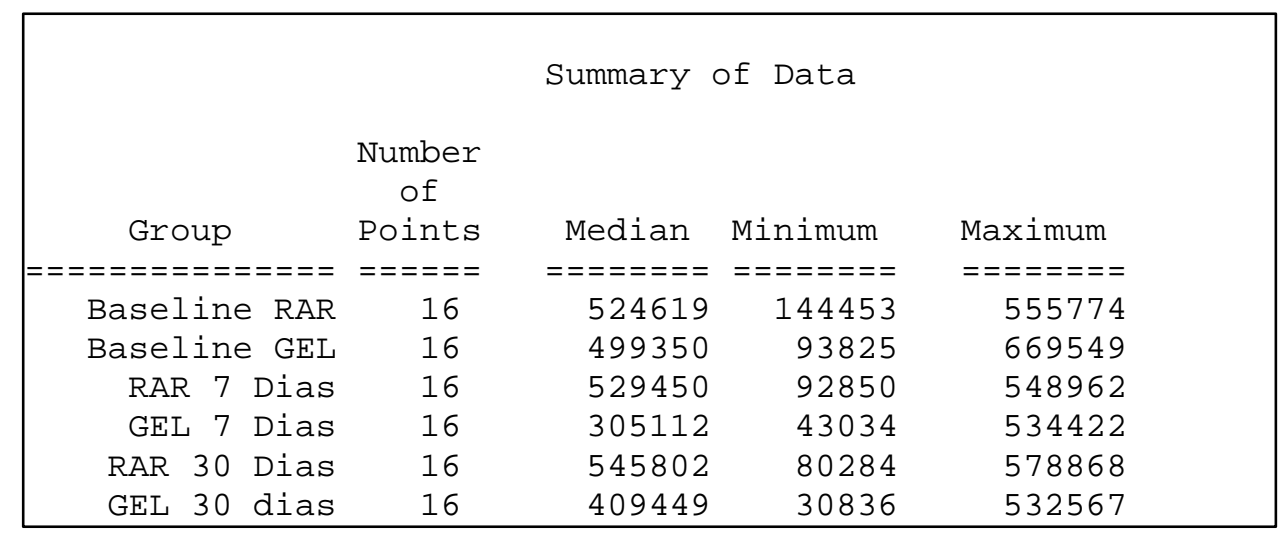

\section{B. fragilis}

Kruskal-Wallis Test (Nonparametric ANOVA)

The $\mathrm{P}$ value is 0.0001 , considered extremely significant. Variation among column medians is significantly greater than expected by chance.

\begin{tabular}{|cccc|}
\hline Calculation detail & & & \\
& $\begin{array}{c}\text { Number } \\
\text { of } \\
\text { Points }\end{array}$ & $\begin{array}{c}\text { Sum } \\
\text { of } \\
\text { Ranks } \\
\text { Group }\end{array}$ & $\begin{array}{c}\text { Mean } \\
\text { of } \\
\text { Ranks }\end{array}$ \\
$=============$ & $=====$ \\
Baseline RAR & 16 & 1084.0 & 67.750 \\
Baseline gel & 16 & 902.00 & 56.375 \\
RAR 7 dias & 16 & 847.00 & 52.938 \\
GEL 7 Dias & 16 & 436.00 & 27.250 \\
RAR 30 dias & 16 & 875.00 & 54.688 \\
GEL 30 dias & 16 & 512.00 & 32.000 \\
\hline
\end{tabular}


Kruskal-Wallis Statistic $\mathrm{KW}=25.038$

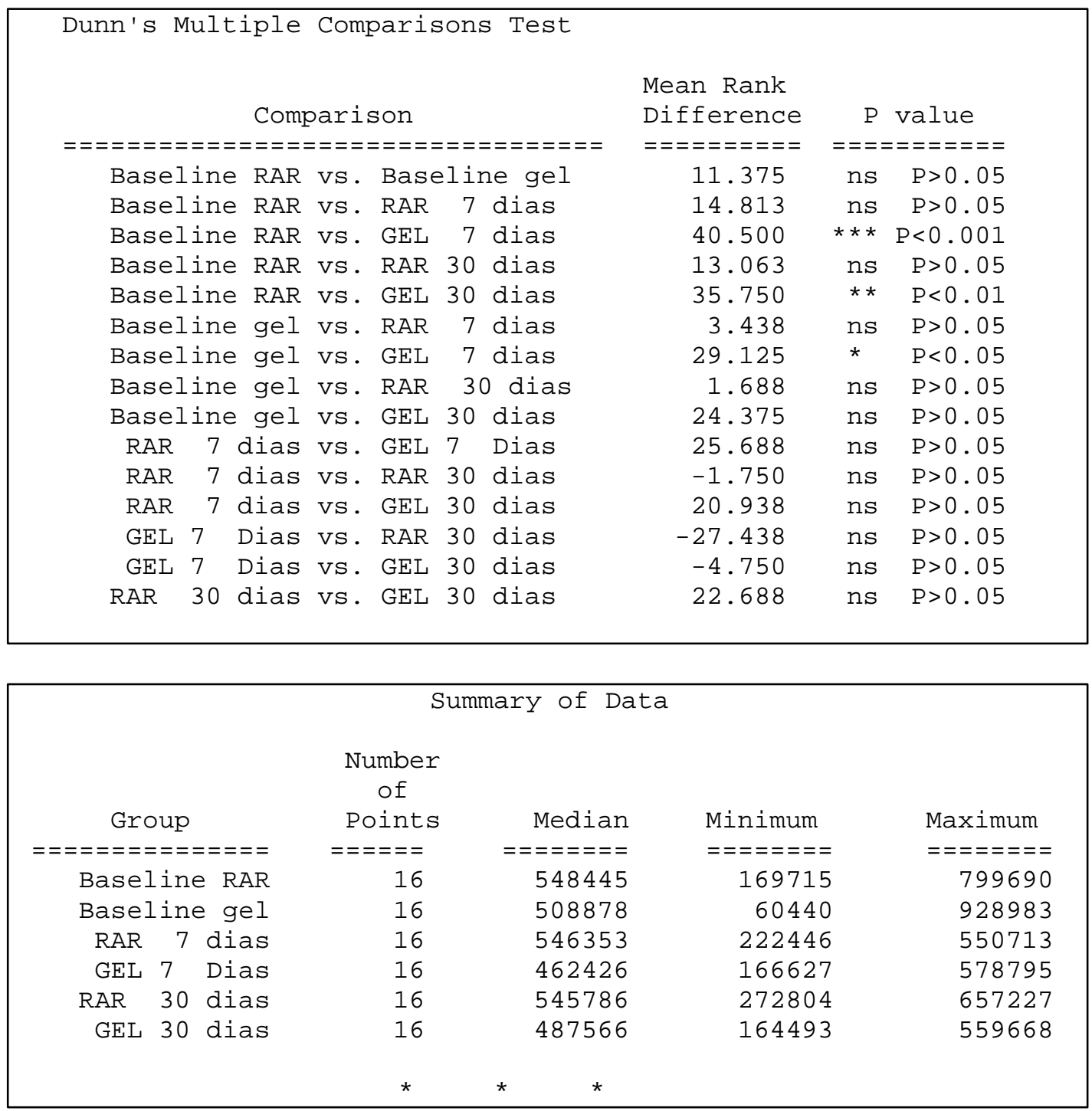

\section{T. forsythensis}

Kruskal-Wallis Test (Nonparametric ANOVA)

The $P$ value is 0.0189 , considered significant

\begin{tabular}{|c|c|c|c|}
\hline \multicolumn{4}{|c|}{ Calculation detail } \\
\hline 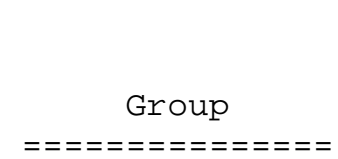 & $\begin{array}{l}\text { Number } \\
\text { of } \\
\text { Points } \\
======\end{array}$ & $\begin{array}{c}\text { Sum } \\
\text { of } \\
\text { Ranks } \\
======\end{array}$ & $\begin{array}{l}\text { Mean } \\
\text { of } \\
\text { Ranks } \\
======\end{array}$ \\
\hline Baseline RAR & 16 & 941.00 & 58.813 \\
\hline Baseline GEL & 16 & 630.00 & 39.375 \\
\hline RAR 7 Dias & 16 & $925.0 \odot$ & 57.813 \\
\hline GEL 7 Dias & 16 & 603.00 & 37.688 \\
\hline RAR 30 Dias & 16 & 962.00 & 60.125 \\
\hline Kruskal-wallis & stic 16 & 13.595 .00 & 37.188 \\
\hline
\end{tabular}




\begin{tabular}{|c|c|c|c|c|c|}
\hline \multicolumn{6}{|c|}{ Dunn's Multiple Comparisons Test } \\
\hline \multicolumn{3}{|c|}{ Comparison } & $\begin{array}{l}\text { Mean Rank } \\
\text { Difference } \\
\text { =ニニニニニニニニ= }\end{array}$ & \multicolumn{2}{|c|}{ P value } \\
\hline Baseline & RAR & vs. Baseline GEL & 19.438 & ns & $P>0.05$ \\
\hline Baseline & RAR & vs. RAR 7 Dias & 1.000 & ns & $P>0.05$ \\
\hline Baseline & RAR & vs. GEL 7 Dias & 21.125 & ns & $P>0.05$ \\
\hline Baseline & RAR & vs. RAR 30 Dias & -1.313 & ns & $P>0.05$ \\
\hline Baseline & RAR & vS. GEL 30 dias & 21.625 & ns & $P>0.05$ \\
\hline Baseline & GEL & vs. RAR 7 Dias & -18.438 & ns & $P>0.05$ \\
\hline Baseline & GEL & vs. GEL 7 Dias & 1.688 & ns & $P>0.05$ \\
\hline Baseline & GEL & vs. RAR 30 Dias & -20.750 & ns & $P>0.05$ \\
\hline Baseline & GEL & vs. GEL 30 dias & 2.188 & ns & $P>0.05$ \\
\hline RAR 7 & Dias & vs. GEL 7 Dias & 20.125 & ns & $P>0.05$ \\
\hline RAR 7 & Dias & vs. RAR 30 Dias & -2.313 & ns & $P>0.05$ \\
\hline RAR 7 & Dias & vs. GEL 30 dias & 20.625 & ns & $P>0.05$ \\
\hline GEL 7 & Dias & vs. RAR 30 Dias & -22.438 & ns & $P>0.05$ \\
\hline GEL 7 & Dias & vs. GEL 30 dias & 0.5000 & ns & $P>0.05$ \\
\hline RAR 30 & Dias & vs. GEL 30 dias & 22.938 & ns & $P>0.05$ \\
\hline
\end{tabular}

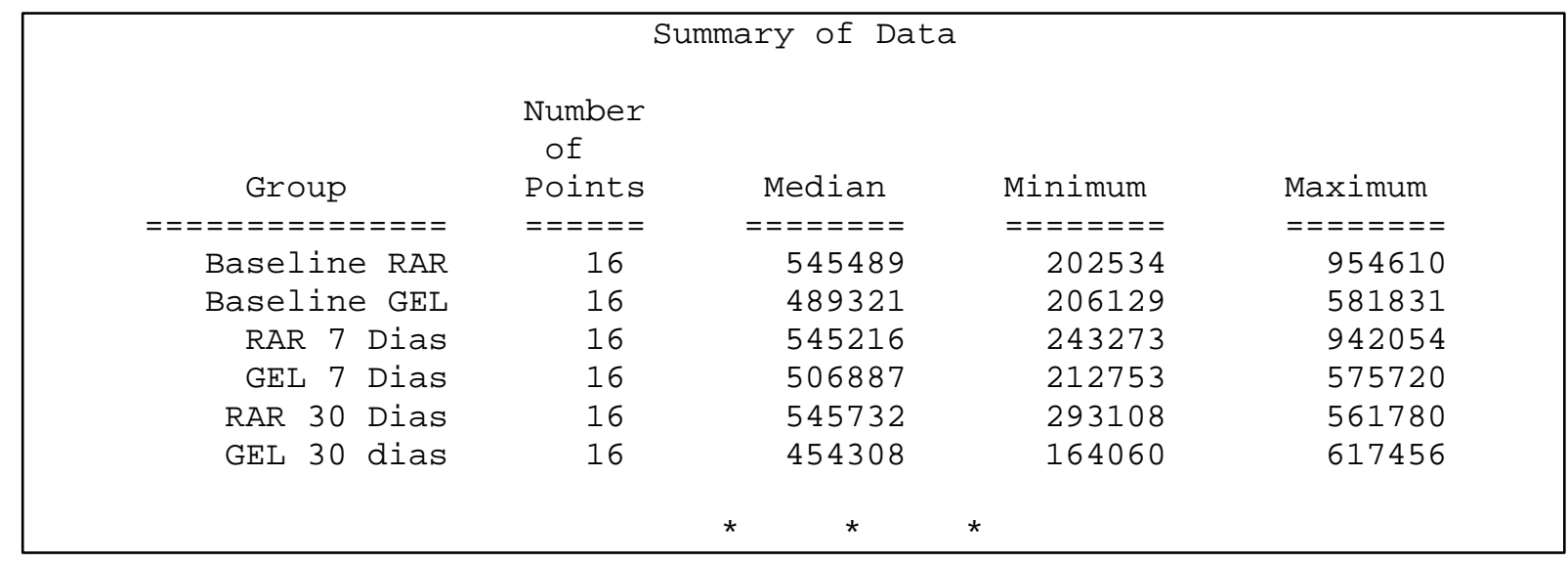

\section{T. denticola}

Kruskal-Wallis Test (Nonparametric ANOVA)

The $\mathrm{P}$ value is $<0.0001$, considered extremely significant

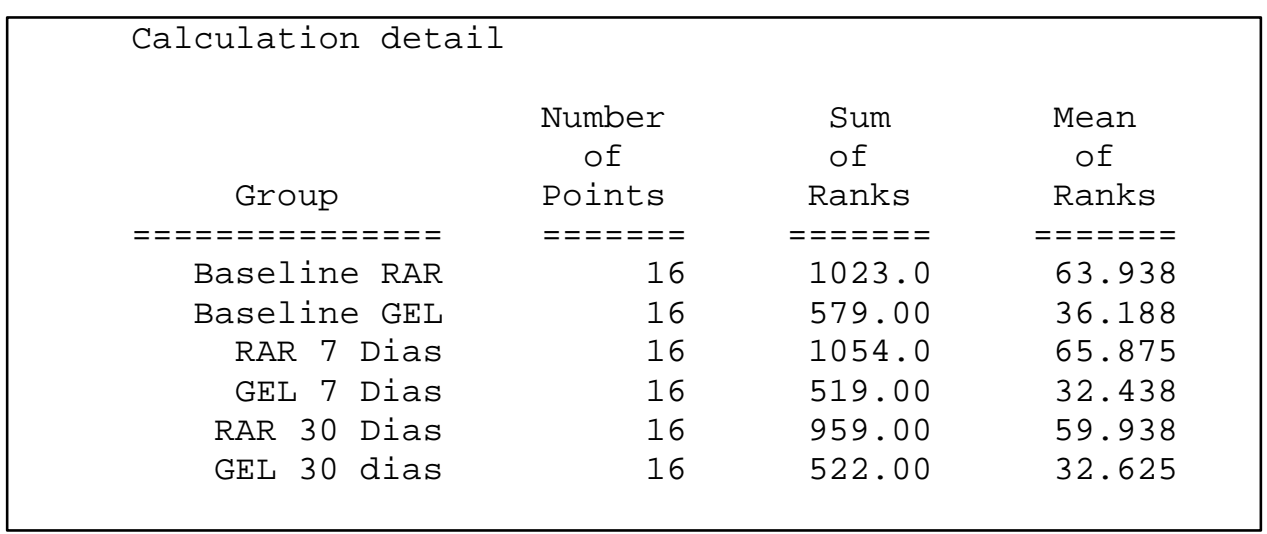


Kruskal-Wallis Statistic $\mathrm{KW}=27.477$

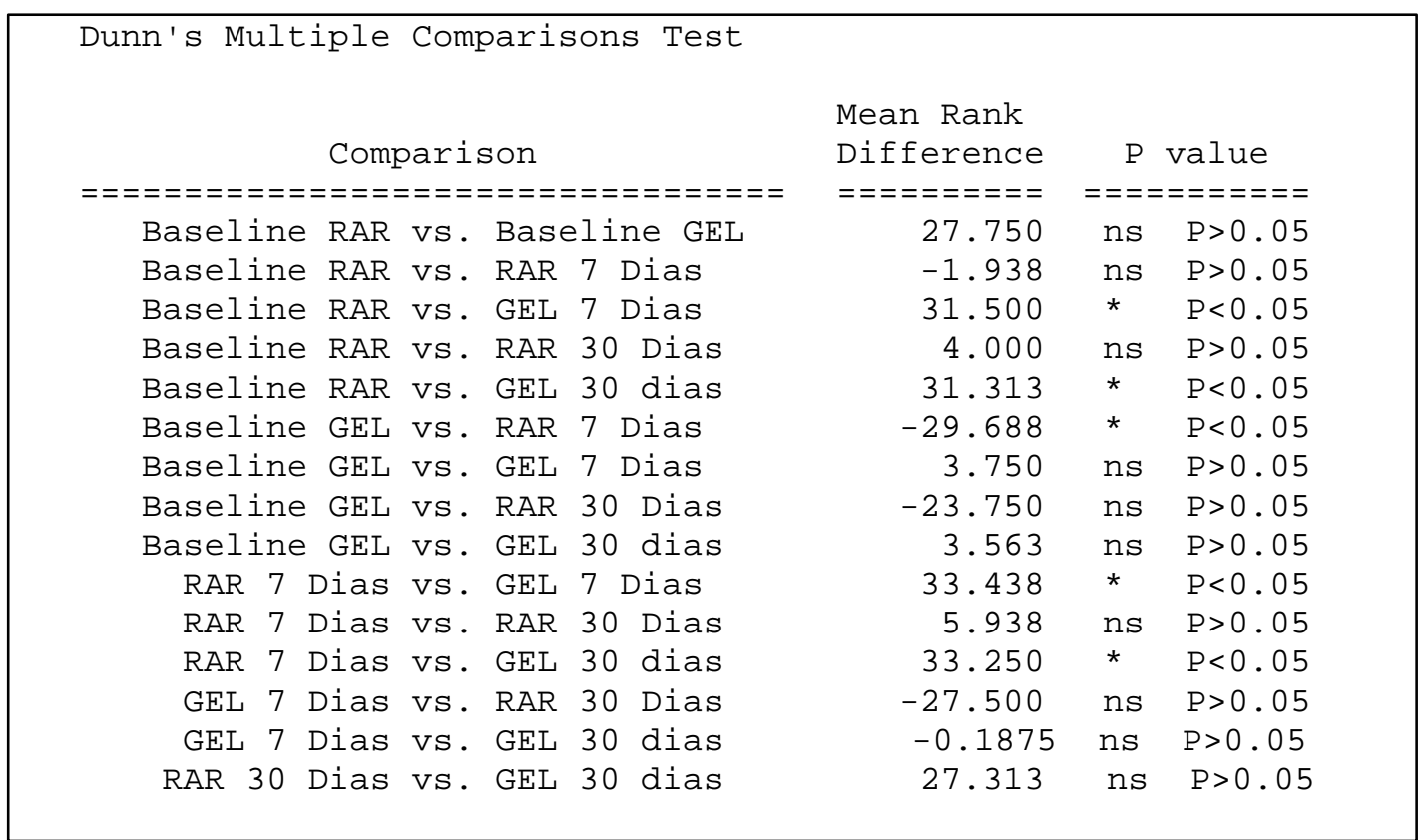

\begin{tabular}{|c|c|c|c|c|}
\hline \multicolumn{5}{|c|}{ Summary of Data } \\
\hline & $\begin{array}{l}\text { Number } \\
\text { of }\end{array}$ & & & \\
\hline 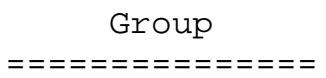 & $\begin{array}{l}\text { Points } \\
=====\end{array}$ & 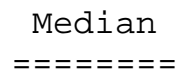 & $\begin{array}{l}\text { Minimum } \\
=======\end{array}$ & $\begin{array}{l}\text { Maximum } \\
=======\end{array}$ \\
\hline Baseline RAR & 16 & 545981 & 189425 & 592046 \\
\hline Baseline GEL & 16 & 370456 & 217458 & 529645 \\
\hline RAR 7 Dias & 16 & 546420 & 135683 & 768417 \\
\hline GEL 7 Dias & 16 & 478360 & 27539 & 533575 \\
\hline RAR 30 Dias & 16 & 544956 & 200124 & 673109 \\
\hline GEL 30 dias & 16 & 452821 & 62898 & 534102 \\
\hline
\end{tabular}


APENDICE C - Imagem demosntrativa de um cromatograma após a análise pela CLAE

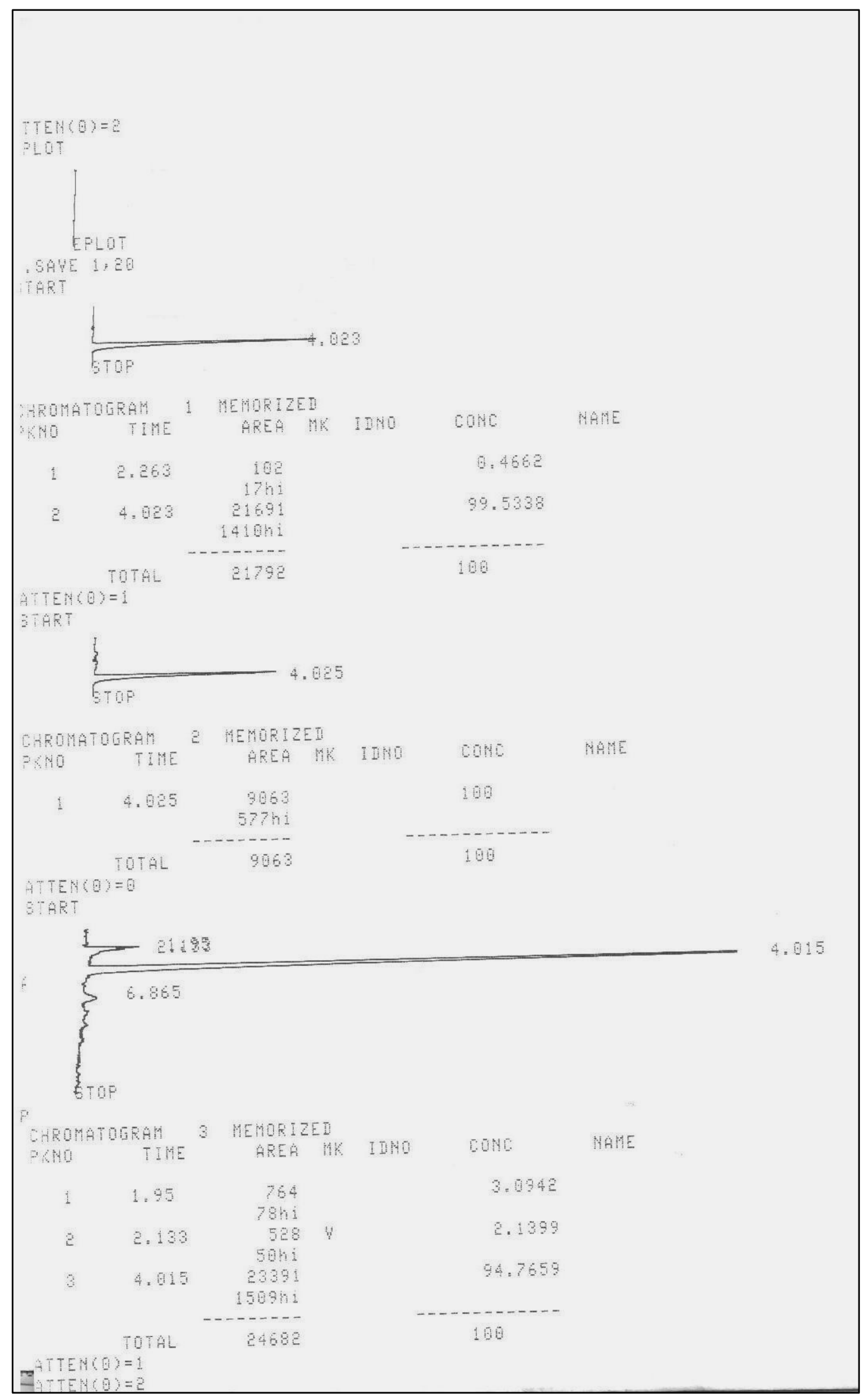


Anexos 


\section{ANEXOS}

\section{ANEXO 1 - Certificado de Aprovação do Projeto pelo Comitê de Ética em Pesquisa da Faculdade de Odontologia da Forp-USP}

\section{UNIVERSIDADE DE SÃO PAULO \\ FACULDADE DE ODONTOLOGIA DE RIBEIRÃO PRETO COMITÊ DE ÉTICA EM PESQUISA}

Avenida do Café, $s / n^{\circ}$. Telefone: (016) 3602-3963

$14040-904$ - Ribeirão Preto - SP - Brasil

Fax: (016) 3633-0999

OF.CEP/455/FORP/13122006

Prezado(a) Professor(a),

Ref.: Processo $n^{\circ}$ 2006.1.1422.58.5

Caae n०0077.0.138.000-06

De ordem da Senhora Coordenadora do Comitê de Ética em Pesquisa desta Facuidade, informamos que o referido Comitê, em sua $74^{a}$ Sessão realizada no dia 13 de dezembro de 2006, deliberou aprovar o Projeto de Pesquisa envolvendo seres humanos intitulado: "Avaliação clínica de formulaçöes semi-sólidas e filmógenas contendo metronidazol para o tratamento da periodontite em humanos", a ser desenvolvido por Vossa Senhoria, na Faculdade de Odontologia de Ribeirão Preto, devendo o atestado para publicação final, ser expedido pelo Comitê de Ética em Pesquisa, após a entrega e aprovação do Relatório Final pelo referido Comitê.

Na oportunidade, lembramos da necessidade de entregar na Secretaria do Comitê, com o formulário preenchido pelo pesquisador responsável, os Relatórios Parciais até os dias $\mathbf{3 1}$ de dezembro de 2007 e $\mathbf{3 1}$ de dezembro de 2008 e o Relatório Final até o dia 31 de dezembro de 2009.

Atenciosamente,

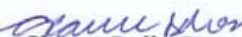

Glauce Della Rosa

Secretária do Comitê de Ética em Pesquisa

$$
\therefore-\cdots
$$

Ilmo. Sr.

Prof. Dr. VINÍcIUS PEDRAZZI

Professor Associado do Departamento de Materiais Dentários e Prótese. 


\section{AnEXo 2 - Exemplo do Termo de Compromisso assinado pelos voluntários da pesquisa}

\section{TERMO DE CONSENTIMENTO LIVRE E ESCLARECIDO}

Eu,

convidado(a) e devidamente esclarecido(a) com a finalidade de autorizar minha participação como sujeito na pesquisa "Avaliação clinica de formulaçöes semí-sólidas e filmógenas contendo metronidazol para o tratamento da periodontite em humanos", sob a

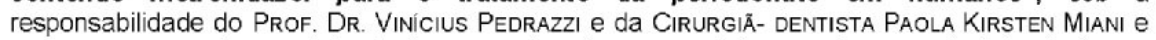
asseguro que me foram dadas todas as explicaçőes necessárias para tomar a decisão de livre e espontânea vontade. Tenho conhecimento que:

Este trabalho visa comparar a eficácia terapêutica de um dispositivo para a liberação controlada de metronidazol, na forma de gel, para tratamento da doença periodontal, em estudo clínico desenvolvido com 20 indivíduos portadores de doença periodontal, em um grupo com idade compreendida entre 30 a 70 anos. Os sujeitos não serão submetidos a regime de washout ou de auséncia de tratamento (placebo). Os 20 indivíduos serão divididos ao acaso nas seguintes grupos: Grupo 1 - raspagem e alisamento radicular (RAR) - controle ativo; Grupo 2 - RAR + gel de metronidazol. Parâmetros clínicos (profundidade à sondagem e nível de inserçăo gengival) e microbiológicos (colheita de placa bacteriana subgengival) serão avaliados no decorrer do estudo. Também o liquido que banha o interior da gengiva será colhido para análise de concentraçăo do medicamento.

1. É condição seletiva desse estudo que eles possuam dentes naturais efou próteses dento-suportadas, e que não apresentem condiçōes sistêmicas indicativas de doenças crônicas, nem estejam fazendo uso de qualquer tipo de antibiótico ou agente antimicrobiano;

2. Com este estudo espera-se avaliar o grau de melhora da saúde periodontal conseguido com tratamento clínico de raspagem e alisamento radicular elou o emprego de sistemas para a liberaçäo controlada de metronidazol;

3. Efeitos colaterais adversos severos não são esperados, pois os pacientes serão submetidos a uma rigorosa anamnese e os insumos empregados para a obtenção dos sistemas terapéuticos são aprovados como complementos alimentares, e o princípio ativo (metronidazol) é indicado para tratamento de doença periodontal;

4. $\quad$ Em caso de efeitos colaterais moderados a severos, serei excluído (a) do estudo para evitar qualquer tipo de dano à minha saúde;

5. Năo está prevista a ocorrência de qualquer tipo de constrangimento ou ofensa aos indivíduos selecionados;

6. Os pesquisadores se comprometem a prestar assistência integral no decorrer da pesquisa;

7. Caso ocorra algum dano à minha saúde, em razão da minha participação na pesquisa, os pesquisadores serão responsáveis por quaisquer despesas;

8. Os pesquisadores manterăo sigilo sobre a minha participação na pesquisa:

9. Como minha participação é voluntária, tenho direito de interrompê-la em qualquer momento, sem sofrer penalizaçöes;

10. Receberei uma cópia deste termo de consentimento.

Ribeiräo Preto, .......... de .......................................... de 2009.

Paciente ou Responsável

PROF. DR. VINICIUS PEDRAZZI CPF: 073.494.138/23

Telefones para contato: (16) 3602-4008
PAOLA KIRSTEN MIANI CPF 181.067.248.-16

e-mail: pedrazzi@forp.usp.br 